\title{
MAPEAMENTO DE GENES DE RESISTÊNCIA À FERRUGEM E DE QTLs ENVOLVIDOS NA RESISTÊNCIA À SEPTORIOSE EM SOJA
}

\author{
RODRIGO LUIS BROGIN
}

Tese apresentada à Escola Superior de Agricultura

"Luiz de Queiroz", Universidade de São Paulo, para obtenção do título de Doutor em Agronomia, Área de Concentração: Genética e Melhoramento de Plantas.

P I R A C I C A B A

Estado de São Paulo - Brasil

Julho - 2005 


\section{MAPEAMENTO DE GENES DE RESISTÊNCIA À FERRUGEM E DE QTLs ENVOLVIDOS NA RESISTÊNCIA À SEPTORIOSE EM SOJA}

\section{RODRIGO LUIS BROGIN}

Engenheiro Agrônomo

Orientador: Prof. Dr. NATAL ANTONIO VELLO

Tese apresentada à Escola Superior de Agricultura

"Luiz de Queiroz", Universidade de São Paulo, para obtenção do título de Doutor em Agronomia, Área de Concentração: Genética e Melhoramento de Plantas.

P I R A C I C A B A

Estado de São Paulo - Brasil

Julho - 2005 
Dados Internacionais de Catalogação na Publicação (CIP) DIVISÃO DE BIBLIOTECA E DOCUMENTAÇÃO - ESALQ/USP

Brogin, Rodrigo Luis

Mapeamento de genes de resistência à ferrugem e de QTLs envolvidos na resistência à Septoriose em soja / Rodrigo Luis Brogin. - - Piracicaba, 2005.

$93 \mathrm{p}$.

Tese (Doutorado) - - Escola Superior de Agricultura Luiz de Queiroz, 2005. Bibliografia.

1. Ferrugem asiática 2. Fungo fitopatogênico 3. Mancha parda 4. Mapeamento genético 5 . Marcador molecular 6 . Resistência genética vegetal 7. Soja I. Título

CDD 633.34 
Aos meus pais Malu e Luiz,

À minha irmã Rosane,

À minha amada Angélica,

Aos verdadeiros amigos,

Dedico

Aos agricultores brasileiros,

exemplos de coragem,

competência,

luta e disposição,

Ofereço 


\section{AGRADECIMENTOS}

A Deus, em primeiro lugar, pela minha existência e pela força e saúde que me permitiram concretizar esse trabalho;

À Escola Superior de Agricultura "Luiz de Queiroz" (ESALQ/USP), pela estrutura excepcional que possui para a formação profissional dos alunos;

À Embrapa (Empresa Brasileira de Pesquisa Agropecuária), essa riqueza que o País possui, pela estrutura e pessoal excelentes que possibilitaram o desenvolvimento desse trabalho;

Ao Departamento de Genética da ESALQ/USP pela oportunidade oferecida para a realização do curso de doutorado em Genética e Melhoramento de Plantas;

Ao Conselho Nacional de Desenvolvimento Científico e Tecnológico (CNPq) pela bolsa de estudos concedida;

Ao Professor Natal Antonio Vello pela oportunidade, orientação, apoio e confiança durante o desenvolvimento desse trabalho, além do exemplo profissional;

A Carlos Alberto Arrabal Arias, pesquisador da Embrapa Soja, pela amizade, exemplo profissional, disposição, orientação e grande contribuição para a realização desse trabalho;

Aos professores da ESALQ/USP e CENA/USP pelos valiosos ensinamentos durante o curso. A vocês sempre serei grato;

Aos pesquisadores da Embrapa: José F. F. de Toledo, Leones A. Almeida, Cláudio G. P. de Carvalho, Marcelo F. de Oliveira, Álvaro M. Almeida, José T. Yorinori, Vânia B. Castiglioni, João Flávio V. Silva, Alexandre L. Nepomuceno, José R. B. Farias, Léo P. Ferreira, Marley M. Utumi, Vicente de P. C. Godinho, Wilson Veneziano; 
Aos pesquisadores da TMG Romeu A. S. Kiihl e Arlindo Harada, por todo o apoio que me deram;

A Naoki Yamanaka (JIRCAS, Japão), pela amizade, agradável convívio e discussões sobre esse trabalho;

Aos todos os funcionários do Departamento de Genética da ESALQ/USP, em especial a Cândida Vanderléia Oliveira (Léia), Neuza, Maidia, Silvana Nascimento, Marcos Nekatschalow, Claudinei Didoné, Berdan e Valdir;

A todos os funcionários da Embrapa Soja, em especial a Paulo R. C. Andreghetti, Mabel Nakai, Silvana R. R. Marin, César A. da Silveira, Vera L. Pierote, Guilherme Goulart, Roberto Chagas, Alisson Lasmar, Sérgio Herculano;

Aos amigos de Piracicaba: José Ubirajara V. Moreira (Bira), Maria Inez F. Faraldo, Rudimar Conte, Frederico de P. Matta, Adalgisa R. Torres, Maira K. Martins, Fábia Botelho Maranha, Fernando N. Cárdenas, Maria Clideana C. Maia, Vanderlei S. Santos, Glauce Rumin, Karina Martins, Carolina Morgante, Mateus Mondin, Jair Unfried, Fernando Miranda, Vanoli Fronza, Maurisrael Rocha, Angela Lopes, Cláudio Tsutsumi, Édina Moresco, Francisco Farias...;

Aos amigos de Londrina: Luciana Grange, Lizandra L. Catelli, Marisa F. Nicolás, Renata Fuganti, Renata Stolf, Magda Beneventi, Águida Morales, Eliseu Binneck, Viviane e Miguel Marçal, Leandro Diniz, Noelle G. Lemos, Adriana Polizel, Danielle Gregório, Adilson Seifert e Débora Santiago;

Aos funcionários da Embrapa Rondônia, em especial a José Cláudio Alves e Ildeu Alves Ribeiro;

A toda minha família que sempre acompanhou e apoiou essa longa caminhada até aqui; A minha esposa Angélica, que sempre esteve ao meu lado me dando muito amor e apoio nos momentos difíceis e compartilhando as alegrias de nossas conquistas. 


\section{SUMÁRIO}

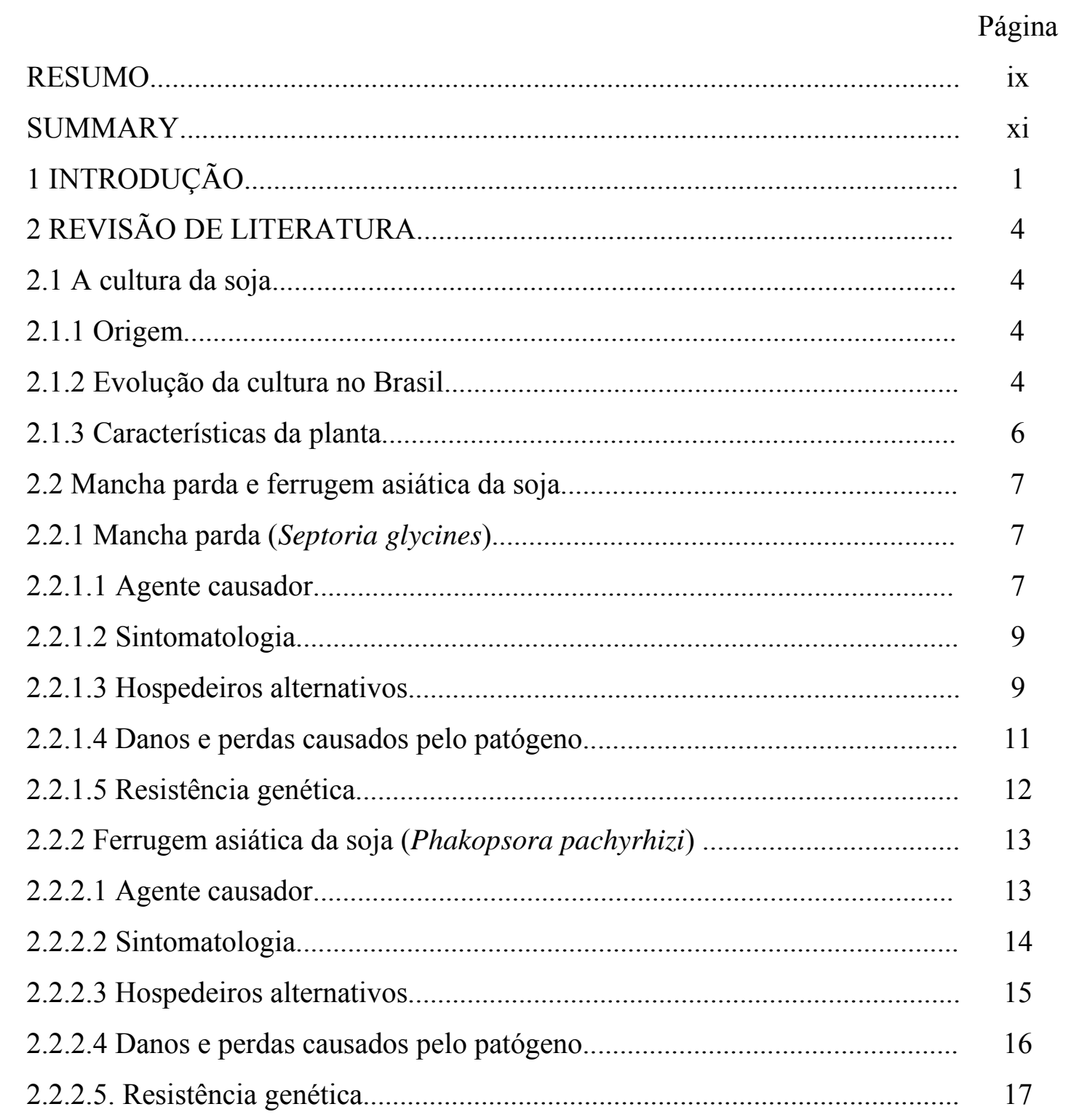




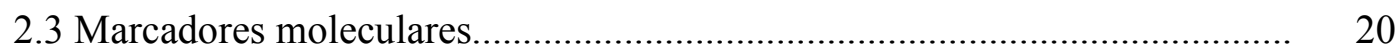

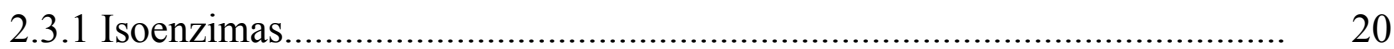

2.3.2 Polimorfismo no comprimento de fragmentos de restrição (RFLP).......... 21

2.3.3 Polimorfismo de DNA amplificado ao acaso (RAPD).............................. 22

2.3.4 Polimorfismo de comprimento de fragmentos amplificados (AFLP)........ 23

2.3.5 Marcadores baseados na amplificação de microssatélites (SSR)............... 24

2.4 Construção de mapas genéticos................................................................... 25

2.5 Marcadores moleculares vs. mapeamento de genes e QTL's envolvidos na resistência de plantas a doenças......................................................................... 26

3 MARCADORES MICROSSATÉLITES FLANQUEANDO UM GENE DOMINANTE DE RESISTÊNCIA Á FERRUGEM ASIÁTICA DA SOJA......

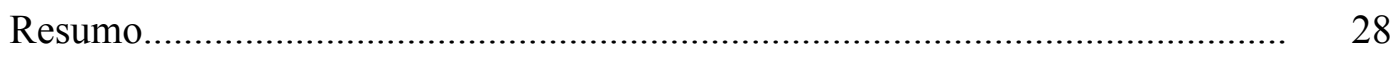

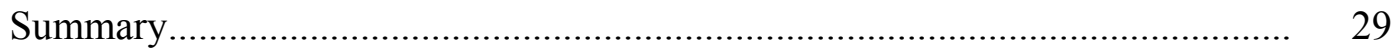

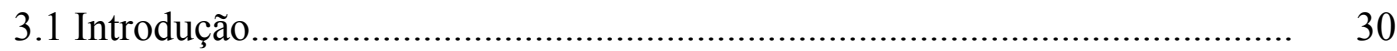

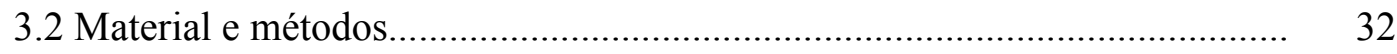

3.2.1 Material genético............................................................................. 32

3.2.2 Delineamento experimental e instalação do experimento............................ 33

3.2.3 Preparo do inóculo e inoculação das plantas com Phakopsora pachyrhizi 33

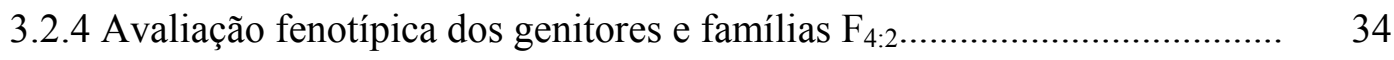

3.2.5 Coleta de tecido foliar......................................................................... 34

3.2.6 Extração de DNA............................................................................... 35

3.2.7 Amplificação de locos microssatélites e visualização dos fragmentos....... 36

3.2.8 Análise de ligação...................................................................................... 37

3.3 Resultados e discussão.......................................................................... 38

3.3.1 Avaliação fenotípica........................................................................... 38

3.3.2 Análise dos marcadores SSR e mapeamento............................................ 38

3.3.3 Utilidade dos marcadores identificados para seleção assistida................... 42

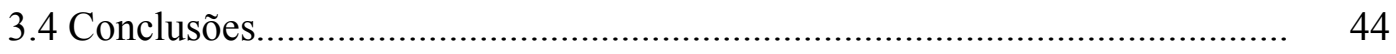


4 MAPEAMENTO DE QTLs ENVOLVIDOS NA RESISTÊNCIA À SEPTORIOSE EM SOJA.............................................................................. 46

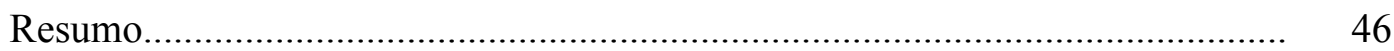

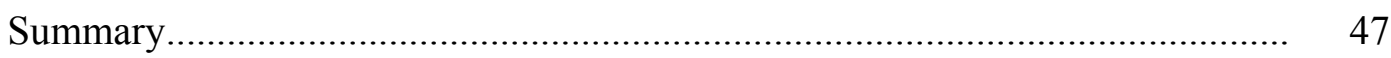

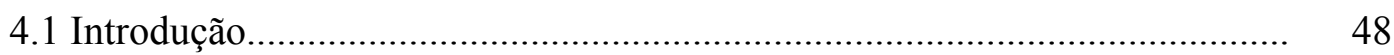

4.2 Material e Métodos............................................................................. 50

4.2.1 Material Genético................................................................................. $\quad 50$

4.2.1.1 Genótipos Parentais............................................................................ 50

4.2.1.2 Gerações Segregantes............................................................................ 50

4.2.2 Delineamento Experimental................................................................... 51

4.2.3 Inóculo de Septoria glycines................................................................... 52

4.2.4 Preparo do inóculo de Septoria glycines..................................................... 52

4.2.5 Inoculação......................................................................................... 53

4.2.6 Avaliações fenotípicas.............................................................................. 54

4.2.7 Análises estatísticas dos dados fenotípicos.............................................. 55

4.2.8 Extração de DNA e genotipagem com marcadores microssatélites............ 57

4.2.8.1 Extração de DNA....................................................................................... 5

4.2.8.2 Amplificações de Microssatélites............................................................ 58

4.2.9 Análise genética dos dados fenotípicos e mapeamento.............................. 59

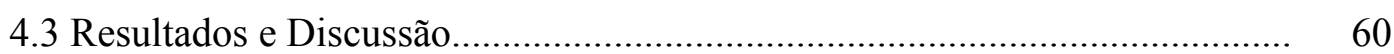

4.3.1 Avaliação das progênies $\mathrm{F}_{3: 2}$ e $\mathrm{F}_{4: 2}$ para resistência a S. glycines............... 60

4.3.2 Construção do mapa genético de ligação................................................... 66

4.3.3 Marcadores SSR associados a resistência a S. glycines.............................. 68

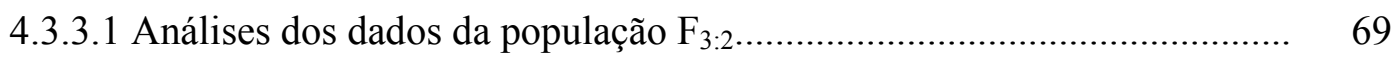

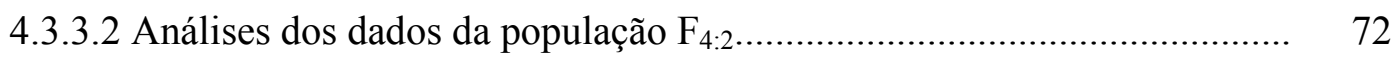

4.3.3.3 Análise de mapeamento por intervalo...................................................... 74

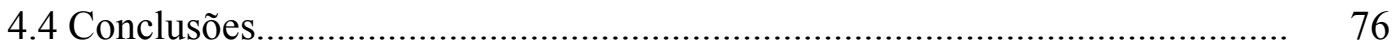

5 CONCLUSÕES GERAIS....................................................................... 77

REFERÊNCIAS BIBLIOGRÁFICAS ...................................................... 78 


\title{
MAPEAMENTO DE GENES DE RESISTÊNCIA À FERRUGEM E DE QTLS ENVOLVIDOS NA RESISTÊNCIA À SEPTORIOSE EM SOJA
}

\author{
Autor: RODRIGO LUIS BROGIN \\ Orientador: Prof. Dr. NATAL ANTONIO VELLO
}

\section{RESUMO}

A ocorrência de doenças em soja tem aumentado nos últimos anos, provocando grandes perdas em plantios comerciais e exigindo respostas rápidas da pesquisa para desenvolvimento e aplicação de técnicas de controle. Mais de 40 doenças afetam a cultura da soja em todo o mundo e dentre elas estão a ferrugem asiática (Phakopsora pachyrhizi Sydow) e a septoriose ou mancha parda (Septoria glycines Hemmi). Estas doenças estão disseminadas em praticamente todas as regiões produtoras de soja do Brasil. Os objetivos desse trabalho foram mapear o gene que confere resistência a $P$. pachyrhizi presente na cultivar de soja FT-2 e QTLs envolvidos na resistência a $S$. glycines, utilizando uma população de plantas $F_{2}$ derivada do cruzamento entre as cultivares FT-2 (resistente) e Davis (suscetível). Marcadores microssatélites foram testados nos genitores, sendo os polimórficos utilizados para genotipar as plantas da geração $F_{2}$. Progênies $F_{3: 2}$ e $F_{4: 2}$ foram obtidas e avaliadas para reação às doenças. Para a ferrugem da soja foram detectados cinco marcadores associados ao caráter, sendo que dois deles (Satt079 e Satt307) flanqueiam o gene dominante de resistência, que foi mapeado no grupo de ligação C2 da soja. Uma eficiência de seleção de $100 \%$ foi obtida com o uso simultâneo destes dois últimos marcadores, indicando que os mesmos podem 
ser ferramentas úteis para a seleção assistida de genótipos homozigóticos resistentes. Para a mancha parda, análises de regressão e de variância foram realizadas para identificar associações significativas entre marcadores e QTLs devido a efeitos aditivos e não aditivos do caráter. Foi realizado, também, o mapeamento por intervalo dos QTLs. As análises de regressão detectaram maior número de marcadores ligados a QTLs do que o mapeamento por intervalo; houve concordância entre os resultados dos dois métodos em apenas um caso, no qual o marcador Satt277, pertencente ao grupo de ligação $\mathrm{C} 2$, foi relacionado significativamente ao caráter. 


\title{
MAPPING RESISTANCE GENES TO SOYBEAN RUST AND QTLS INVOLVED IN BROWN SPOT RESISTANCE IN SOYBEAN
}

\author{
Author: RODRIGO LUIS BROGIN \\ Adviser: Prof. Dr. NATAL ANTONIO VELLO
}

\section{SUMMARY}

The occurrence of soybean diseases that causes large yield losses in commercial fields has increased in recent years forcing research to face the challenge of providing quick responses to develop control techniques. More than 40 diseases affect soybeans worldwide, among them the Asian rust (Phakopsora pachyrhizi Sydow) and brown spot (Septoria glycines Hemmi). These diseases are spread in practically all Brazilian soybean cropping areas. The objectives of this work was to map the resistance gene to $P$. pachyrhizi and the QTLs involved in the resistance to S. glycines in the soybean cultivar FT-2, using an F2 plant population derived from the cross between FT-2 (resistant) and Davis (susceptible). SSR markers were tested in the parents and those showing polymorphism were used to screen plants of the F2 generation. F3:2 and F4:2 progenies were evaluated for disease reaction. Five markers associated to soybean rust resistance were detected and two (Satt079 and Satt307) are flanking a dominant resistance gene that was mapped in the $\mathrm{C} 2$ soybean linkage group. An efficiency of $100 \%$ was obtained with the simultaneous use of those markers for selection, which indicated that they could be useful in marker-assisted selection of resistant homozygous genotypes. For brown spot resistance, regression analyses and ANOVAs were performed to identify significant associations between markers and resistance QTL's showing additive and non-additive 
effects. The interval mapping of the QTL's was also performed. The regression analyses detected more markers linked to QTL's than the interval analyses. Only the Satt277 marker (soybean linkage group C2) was significantly associated to the trait by both detection methods. 


\section{INTRODUÇÃO}

Desde o início do cultivo da soja no Brasil, grandes avanços tecnológicos foram obtidos pela pesquisa durante as últimas décadas, tanto para a melhoria do complexo ambiental, como também para a melhoria do potencial genético das cultivares. Esses avanços se refletiram na evolução da produtividade média da soja no país, que era de $1.748 \mathrm{~kg} / \mathrm{ha}$ na safra de 1976/77 e, na safra de 2003/04 foi de $2.339 \mathrm{~kg} / \mathrm{ha}$ (CONAB, 2005). Esse aumento de produtividade, que seria maior caso não ocorressem problemas como falta de chuvas e doenças como a ferrugem asiática, juntamente com o aumento da área cultivada com o grão, contribuiu para colocar o Brasil como o segundo maior produtor mundial de soja, com estimativas de produção na safra 2004/05 de 50,2 milhões de toneladas. Quanto à melhoria do material genético utilizado pelos produtores no Brasil, ou seja, das cultivares de soja desenvolvidas através de pesquisa em instituições públicas e privadas oferecidas aos produtores pelo mercado, avanços têm sido obtidos a cada ano com relação à produtividade desses genótipos. O melhoramento genético da soja, que aliado a outras áreas de pesquisa como por exemplo fitopatologia, entomologia e biotecnologia, faz com que seja obtido o aumento da produtividade dos genótipos, para que estes se mantenham competitivos no mercado como novas cultivares.

A produtividade e a estabilidade das cultivares atuais de soja, desenvolvidas através de melhoramento genético, são características muito importantes para a aceitação comercial por parte dos produtores. Dentre os fatores que garantem a estabilidade dessas cultivares, está a resistência genética a doenças, que é o método de controle mais 
eficiente e barato para os produtores e mais adequado às práticas de conservação do ambiente.

A ocorrência de doenças em soja tem aumentado nos últimos anos, provocando grandes perdas em plantios comerciais e exigindo respostas rápidas da pesquisa para desenvolvimento e aplicação de técnicas de controle. Problemas com doenças economicamente importantes como a mancha olho-de-rã (Cercospora sojina) e o cancro da haste (Diaporthe phaseolorum) foram rapidamente solucionados com a incorporação de genes de resistência nas cultivares. Foi um processo rápido em função da herança genética relativamente simples e da existência de métodos eficientes de avaliação desenvolvidos pela pesquisa. Outros problemas, como as perdas provocadas pelo "complexo doenças de final de ciclo" (Septoria glycines e Cercospora kikuchii), nematóides de galha (Meloydogine spp.) e de cisto (Heterodera glycines) e, principalmente, pela ferrugem asiática da soja (Phakopsora pachyrhizi), têm se agravado nos últimos anos.

Dentre as doenças que ocorrem no final do ciclo da soja, a mancha parda ou septoriose, causada pelo fungo Septoria glycines, está disseminada por todas as regiões brasileiras produtoras de soja, diferindo em importância de uma região para outra. Como se trata de uma doença de difícil avaliação a campo, pois existem outros patógenos infectando as plantas de soja no final do ciclo, as avaliações do nível de perdas provocadas tornam-se questionáveis. Embora pouco precisas, as estimativas de perdas existentes na literatura são normalmente elevadas, variando muito em função do clima predominante da região, do ano de avaliação e da cultivar utilizada. Existe diferença quanto à reação das cultivares ao patógeno. No entanto, a resistência das cultivares não é suficiente para evitar a aplicação de fungicidas em algumas regiões de cultivo da soja.

Outra doença, que também pode ocorrer no final do ciclo da soja, é a ferrugem asiática (Phakopsora pachyrhizi), que tem sido verificada nos hemisférios oriental e ocidental, incluindo a África, representando uma grande ameaça para os países do continente americano. Essa doença já causa grandes perdas em muitos países, principalmente no continente asiático (Bromfield \& Yang, 1976; Hartman et al., 1999), e vem causando perdas também no Brasil. De acordo com as informações da safra de soja 
2002/2003, perdas de até $90 \%$ ocorreram em algumas propriedades do estado da Bahia, onde a doença ocorreu com alta severidade (Yorinori, 2004). Na safra 2003/04, de acordo com informações da Embrapa, também ocorreram muitas perdas devido à presença desse patógeno; considerando-se o custo com o controle da doença e a redução da produtividade, foram calculados prejuízos de mais de US\$ 3 milhões. Na safra 2004/05 foi criado, por iniciativa do Ministério da Agricultura, Pecuária e Abastecimento, o Consórcio Anti-Ferrugem, formado por vários elos da cadeia produtiva da soja, com o principal objetivo de difundir informações sobre o patógeno e sobre seu controle, que atualmente é somente o químico.

De acordo com o exposto, há necessidade de desenvolvimento de genótipos de soja resistentes às principais doenças que ocorrem no país. Visto que os recursos aplicados em um programa de melhoramento genético são relativamente altos, devido principalmente às avaliações extensivas dos genótipos, há necessidade de criação de estratégias para aumentar sua eficiência. Metodologias ou mecanismos de seleção que possibilitem identificar genótipos promissores, logo no início da fase de avanço de gerações após os cruzamentos, são de grande interesse. Uma dessas metodologias é a identificação de marcadores moleculares ligados a genes que conferem resistência a patógenos, o que permite monitorar e acelerar a introdução desses genes no germoplasma cultivado.

Portanto, os objetivos desse trabalho são identificar e mapear genes e QTL's envolvidos na resistência da soja à mancha parda (Septoria glycines) e à ferrugem asiática (Phakopsora pachyrhizi), utilizando marcadores moleculares microssatélites. 


\section{REVISÃO DE LITERATURA}

\subsection{A cultura da soja}

\subsubsection{Origem}

O centro primário de diversidade da soja está localizado na região leste da Ásia, provavelmente na região Centro-Sul da China. A Manchúria, região chinesa onde a soja foi domesticada, constitui o centro secundário (Xu et al., 1989). O conhecimento do centro de origem de uma espécie cultivada é muito importante para o sucesso de um programa de melhoramento, pois freqüentemente há necessidade de se buscar no centro primário a variabilidade para solucionar os problemas que estão constantemente surgindo, como novas doenças e pragas.

\subsubsection{Evolução da cultura no Brasil}

Dentre as espécies vegetais cultivadas de maior importância econômica e social para o Brasil, a soja [Glycine max (L.) Merrill] é a que mais se destaca. Devido ao seu valor econômico e social e também ao melhoramento genético, que desenvolveu cultivares de soja adaptadas às mais diversas condições e mais resistentes às diversas pragas e doenças, houve uma rápido crescimento da cultura no Brasil nos últimos 40 anos. A expansão do cultivo teve início no final dos anos de 60 , tornando-se, em curto período de tempo, um dos principais produtos da exploração agrícola e da economia 
nacional. Desde o início da produção comercial até a safra de 2003/04, a área cultivada nacional aumentou de 702 para 21.284,1 mil hectares, a produção de 457 para 49.792,7 mil toneladas e a produtividade média de 651 para $2.339 \mathrm{Kg} / \mathrm{ha}$ (Bonato \& Bonato, 1987; CONAB, 2005). Quase a totalidade da área cultivada com soja no Brasil está distribuída nos principais estados produtores: Mato Grosso, Paraná, Goiás, Rio Grande do Sul, Mato Grosso do Sul, Minas Gerais e Bahia. Atualmente, o Brasil participa com $20 \%$ da produção mundial de soja, sendo o segundo maior produtor dessa oleaginosa. Os Estados Unidos são o maior produtor de soja, participando com $46 \%$ da produção mundial.

A previsão da produção de soja no Brasil na safra 2004/05 era de 57 milhões de toneladas, que superaria em 14,6\% àquela do ano passado. Havia também a expectativa de aumento na produtividade de $6,7 \%$ em relação à safra anterior. No entanto, a estiagem foi severa, principalmente no Rio Grande do Sul e no Paraná, ocasionando a redução da produtividade. Na região Centro-Oeste, os Estados do Mato Grosso do Sul e Mato Grosso, também foram afetados pela falta de chuvas regulares durante o início de desenvolvimento das lavouras, nos meses de dezembro e janeiro. No Mato Grosso, também ocorreram perdas, principalmente de qualidade dos grãos, devido a chuvas contínuas no período de colheita em várias regiões. Além disso, a ferrugem asiática também ocasionou perdas na produtividade em algumas regiões do estado de Mato Grosso. Como conseqüência, na última estimativa da CONAB (2005), foi constatada a produção de 50,2 milhões de toneladas do grão e a produtividade foi reduzida em 7,1\%.

Mesmo com a redução da safra, a produção brasileira ainda apresentou resultado expressivo, com destaque para a região Centro-Oeste que passou de 24,6 (2003/04) para 27,9 (2004/05) milhões de toneladas, ou seja, um aumento de 13,4\%.

A área plantada com a soja na safra 2004/05 no Brasil aumentou em 8,6\%, totalizando 23,1 milhões de hectares, ocupando, principalmente, áreas de cultivo de milho que diminuíram 5,0\%. 


\subsubsection{Características da planta}

A soja é uma planta herbácea, anual, ereta, de crescimento morfológico diversificado, idêntico ao feijão-comum, diferenciando-se, além de outros caracteres, pelas hastes e vagens pubescentes e pelo porte ereto. A altura varia de 0,3 a 2,0 metros, podendo ser muito ou pouco ramificada. Dependendo da cultivar e condições ambientais, o ciclo da soja varia de 80 a 200 dias (Sediyama et al., 1985). A espécie cultivada possui $2 \mathrm{n}=40$ cromossomos, pertencendo à família Fabaceae, divisão Magnoliophyta, classe Magnoliopsida, sub-classe Rosidae e ordem Fabales (Capellari Jr. et al., 1999).

A soja apresenta elevado teor de proteína, podendo ser utilizada na substituição ou complementação dos alimentos derivados de animais. Segundo Oliveira (1981), a soja é de importância fundamental na alimentação humana, devido aos teores elevados de óleo e proteína e, também, por ser fonte de vitaminas (tiamina e riboflavina) e minerais (cálcio e ferro).

Durante o desenvolvimento de uma planta de soja, aparecem quatro tipos distintos de folhas: (a) dois cotilédones, que constituem o primeiro par; (b) um par de folhas simples, ou primárias, unifolioladas, que se sucedem aos cotilédones; (c) as folhas trifolioladas que seguem as primárias e constituem todas as demais folhas da planta e (d) os prófilos, pequenos e pouco diferenciados, que se encontram nas bases dos ramos laterais (Müller, 1981).

Fehr \& Caviness (1981) caracterizaram os estádios de crescimento de plantas, baseados no número de nós, no desenvolvimento das folhas e das flores (Quadro 1). 


\begin{tabular}{|l|l|}
\hline \multicolumn{2}{|c|}{ ESTÁDIOS VEGETATIVOS } \\
\hline $\mathbf{V}_{\mathbf{e}}$ & Emergência - Cotilédones acima da superfície do solo. \\
\hline $\mathbf{V}_{\mathbf{c}}$ & Estádio cotiledonar - Folhas unifolioladas não desenvolvidas completamente. \\
\hline $\mathbf{V}_{\mathbf{1}}$ & $1^{\mathbf{0}}$ Nó - Folha completamente desenvolvida no nó unifoliolado. \\
\hline $\mathbf{V}_{\mathbf{2}}$ & $2^{\mathbf{o}}$ Nó - Trifólio completamente desenvolvido acima do nó unifoliolado. \\
\hline $\mathbf{V}_{\mathbf{3}}$ & $3^{\mathbf{0}}$ Nó - Trifólio completamente desenvolvido acima do segundo nó. \\
\hline $\mathbf{V}_{\mathbf{4}}$ & $4^{\mathbf{0}}$ Nó - Trifólio completamente desenvolvido acima do terceiro nó. \\
\hline $\mathbf{V}_{\mathbf{n}}$ & $\mathrm{n}$ = número de nós da haste principal com trifólios completamente desenvolvidos. \\
\hline \multicolumn{2}{|c|}{ ESTÁDIOS REPRODUTIVOS } \\
\hline $\mathbf{R}_{\mathbf{1}}$ & Uma flor em qualquer nó. \\
\hline $\mathbf{R}_{\mathbf{2}}$ & Floração completa. \\
\hline $\mathbf{R}_{3}$ & Início da formação de vagens $( \pm 5 \mathrm{~mm})$. \\
\hline $\mathbf{R}_{\mathbf{4}}$ & Formação de vagens completas $( \pm 2 \mathrm{~cm})$ \\
\hline $\mathbf{R}_{\mathbf{5}}$ & Início da formação de sementes $( \pm 3 \mathrm{~mm})$ \\
\hline $\mathbf{R}_{\mathbf{6}}$ & Formação de sementes completas \\
\hline $\mathbf{R}_{7}$ & Início da maturação (50 \% das folhas amareladas ou maturação fisiológica) \\
\hline $\mathbf{R}_{\mathbf{8}}$ & 95\% dos legumes de cor palha a marrom (maturação completa ou ponto de colheita). \\
\hline
\end{tabular}

Quadro 1. Estádios de crescimento de plantas de acordo com Fehr \& Caviness (1981)

\subsection{Mancha parda e ferrugem asiática da soja}

\subsubsection{Mancha parda (Septoria glycines)}

\subsubsection{Agente causador}

A presença do fungo Septoria glycines Hemmi, agente causal da "mancha parda" da soja, foi relatado pela primeira vez nos Estados Unidos por Wolf \& Lehman (1926), na Carolina do Norte. Entretanto, logo se tornou evidente que a doença em estudo era idêntica à descrita por Hemmi (1915), em folhas de soja nas províncias de Kimatai, Ishikari, Tokashi e Buri no Japão. No Canadá, Benedict (1964), reporta que a doença foi observada pela primeira vez por volta de 1934. No Brasil, o relato da ocorrência de mancha parda foi feito por Luzzardi et al. (1972), em Pelotas, no Estado do Rio Grande do Sul, em amostras de soja colhidas no ensaio de cultivares de soja do IPEAS. Esta doença ocorre na mesma época do crestamento foliar provocado pelo fungo 
Cercospora kikuchii e, devido às dificuldades que apresentam nas avaliações individuais, são consideradas como um "complexo de doenças de final de ciclo".

Há relatos desse patógeno nas mais diversas regiões do mundo onde se cultiva soja, desde a Ásia até as Américas (Tisseli et al., 1980). No Brasil, ocorre desde a região Sul, de clima subtropical, até o cerrado, caracterizado pelo clima quente (Yorinori et al., 1993).

Para que ocorra a infecção pelo patógeno é preciso um determinado período após seu contato com a planta para que os esporos germinem. Após 24 horas, a $25^{\circ} \mathrm{C}, 43$ $\%$ dos esporos germinam, ao passo que num período maior (48 horas) à temperatura de $22^{\circ} \mathrm{C}, 25^{\circ} \mathrm{C}$ e $28^{\circ} \mathrm{C}$, ocorre $83 \%$ de germinação dos esporos (Almeida, 1978). Picinini \& Costa Neto (1979), estudando o fungo em meio de cultura batata-dextrose-ágar (BDA), verificaram grande produção de esporos em temperatura ambiente $\left(23{ }^{\circ} \mathrm{C}\right.$ a 30 ${ }^{\circ} \mathrm{C}$ ) e em câmara climatizada, com $27^{\circ} \mathrm{C}$ a $28^{\circ} \mathrm{C}$, sendo que a produção de esporos foi maior em luminosidade contínua. No entanto, Almeida (1978) relatou que a germinação dos esporos não é afetada pela luz, mas apenas pela temperatura.

Outro fator importante para o desenvolvimento do patógeno é a umidade do ambiente e a água livre nas folhas. Para estudar se o efeito da nebulização das folhas de soja, simulando formação de orvalho, afetaria a severidade da mancha parda, Ross (1982) realizou experimentos com inoculação e posterior período de umidade, utilizando a cultivar de soja Essex. Como resultados, observou que houve um aumento do número de lesões em resposta aos períodos de orvalho simulado, indicando que a severidade da doença poderia ser aumentada pelo orvalho natural durante os estádios pósflorescimento sob condições de campo. Concluiu também que longos períodos de nebulização das folhas poderiam lavar os esporos, reduzindo a severidade da doença.

Quanto à obtenção de inóculo do patógeno, Wolf \& Lehman (1926) reportaram que foi obtida abundante esporulação em diversos meios de batata, batata-ágar, meio de milho esterilizado, fécula de mandioca e vagens de soja esterilizadas.

MacNeill \& Zalasky (1957) realizaram estudos histológicos das relações parasita-hospedeiro entre Septoria glycines Hemmi e folhas e vagens de soja, utilizando uma cultivar de soja suscetível (Mandarin), inoculada quando a primeira folha 
trifoliolada apresentava-se completamente expandida, ou quando as vagens apresentavam metade de seu desenvolvimento completo. Como resultados, observaram que a penetração nas folhas pelo patógeno era efetivada dentro de 24 horas após a inoculação, através dos estômatos e sem nenhuma evidência de apressórios, ocorrendo exclusivamente na parte abaxial da folha, mesmo havendo a presença de estômatos em ambas as faces da folha de soja. A penetração do micélio do fungo em vagens também ocorreu pelos estômatos.

\subsubsection{Sintomatologia}

Segundo Hemmi (1915), a doença aparece primeiramente nos cotilédones como manchas marrom escuras irregulares, variando em tamanho de pequenas pontuações a áreas lesionadas de 2-4 $\mathrm{mm}$ de diâmetro, não excedendo $5 \mathrm{~mm}$. Devido a sua facilidade de infecção, o fungo ataca o par de folhas simples e as folhas verdadeiras (trifólios), causando lesões ligeiramente salientes, angulares e de distintas formas, estando limitadas pelas nervuras secundárias e espalhando-se irregularmente sobre a superfície. A cor das manchas gradualmente se torna marrom escura e, finalmente, marrom enegrecida. Quando velhas, adquirem a coloração acinzentada na região central, podendo ser observados picnídios de coloração escura sobre elas. As lesões podem coalescer, freqüentemente formando grandes manchas marrons ou marrom escuras irregulares, sendo que os tecidos próximos às áreas afetadas tornam-se gradualmente cloróticos e as folhas secam e caem precocemente.

\subsubsection{Hospedeiros alternativos}

De acordo com Hartman \& Lee (1995), Septoria glycines tem sido observada somente em um número limitado de espécies leguminosas, mas pode infectar outros hospedeiros. Estes autores observaram que o algodão selvagem (Abutilon theophrastii 
Medik.), planta encontrada na maioria das áreas de produção de soja dos Estados Unidos, apresentava lesões de mancha parda, o que foi confirmado por isolamento e inoculação de plantas de soja e de algodão selvagem.

Em outro trabalho, com o objetivo de determinar a reação do gênero Glycine spp. e outras leguminosas a S. glycines, Lee \& Hartman (1996) realizaram inoculações a campo e em casa-de-vegetação em trinta gêneros, representando trinta espécies de plantas leguminosas, duas espécies de plantas daninhas (Abutilon theophrastii e Cynanchum laeve) e cinco cultivares de soja. Das espécies inoculadas, 29 leguminosas e Abutilon theophrastii apresentaram lesões nas folhas. Somente Cicer arietinum não apresentou sintomas após as inoculações a campo e em casa-de-vegetação.

Lim \& Hymowitz (1987) avaliaram um total de 186 acessos (PI's - Plant Introductions) de seis espécies perenes selvagens do gênero Glycine e também a cultivar de soja Williams, quanto à reação a $S$. glycines após inoculação a campo. A severidade da mancha parda, medida através da porcentagem de área foliar infectada, variou de $3 \%$ a 37,5 \% nos acessos quando as plantas da cultivar Williams estavam no estádio R6 de crescimento.

Como parte das áreas cultivadas com soja no verão, na região sul do Brasil, é posteriormente utilizada para o cultivo de trigo e de outras espécies vegetais de inverno para adubação verde, Almeida et al. (1981) verificaram se estas espécies vegetais eram hospedeiras do fungo Septoria glycines, dentre outros patógenos estudados no trabalho. As espécies de plantas utilizadas foram Lupinus albus, Lupinus luteus, Vicia sativa, Vicia villosa, Phacelia thanacetifolia, Brassica juncea, Brassica campestris, Brassica napus e Raphanus sativus, as quais foram inoculadas com o patógeno e avaliadas cerca de vinte dias após a inoculação, concluindo-se que nenhuma delas era hospedeira deste patógeno. 


\subsubsection{Danos e perdas causados pelo patógeno}

Estudos desenvolvidos para determinar a época de incidência das doenças de final de ciclo em soja, utilizando fungicidas, mostraram que: os efeitos são mais visíveis após os estádios de completa formação de vagem (R6) e início da maturação (R7.1); aplicações antecipadas não contribuíram para o aumento de rendimento; as aplicações devem ser preventivas, antecedendo a fase final de granação (R5.5) (Ritchie et al.., 1982; Yorinori \& Arias, 1989).

A desfolha precoce pode reduzir a granação em mais de $30 \%$. Essas perdas explicam, em parte, a baixa produtividade nacional da soja, hoje cerca de $2.782 \mathrm{~kg} / \mathrm{ha}$, enquanto que o potencial prático ao nível de lavoura é superior a $4.000 \mathrm{~kg} / \mathrm{ha}$, segundo Yorinori (1988). Lim (1980) verificou reduções de rendimento de 12\% a 34\% após inoculações artificiais do patógeno e, de 8 \%, devido à infecção natural. Outros trabalhos obtiveram resultados semelhantes, como os de Young \& Ross (1978), Backman et al.. (1979), Williams \& Nyvall (1980), Almeida (1980), Pataky \& Lim (1981), Yorinori (1987a), Basu \& Butler (1988) e Cooper (1989).

Wrather et al.. (1997), reunindo informações sobre as estimativas de perdas por doenças dos dez países com as maiores produções de soja no ano agrícola de 1994, concluíram que o nematóide de cisto da soja (Heterodera glycines), o cancro da haste (Diaporthe phaseolorum var. caulivora), a mancha parda (Septoria glycines) e a podridão negra (Macrophomina phaseolina) foram, em ordem de importância, os principais causadores de perdas na produção. Os mesmos autores também afirmaram que a mancha parda e o crestamento causado por Cercospora kikuchii são doenças responsáveis pela desfolha precoce e perdas anuais de aproximadamente 7\% na produtividade em condições naturais.

Estudando os efeitos da mancha parda nos componentes de produtividade da cultivar de soja Williams em duas safras, Pataky \& Lim (1981) observaram que o peso das sementes de plantas inoculadas com Septoria glycines foi significativamente reduzido, quando comparado ao peso das sementes de plantas não inoculadas e pulverizadas com o fungicida benomil. Segundo os autores, a desfolha prematura pode 
ter sido uma das causas da redução do peso das sementes, embora o nível de desfolha tenha sido extremamente severo somente nas fases finais de crescimento. De acordo com os dados obtidos nesse trabalho, os componentes de produtividade número de vagens e número de sementes por vagem, não foram significativamente afetados pela doença, mas podem, juntamente com o componente peso de sementes, ser reduzidos quando a mancha parda e a desfolha precoce forem severos.

Com o objetivo de mensurar as reduções na produtividade causadas por $S$. glycines e Pseudomonas glycinea (P. syringae) em soja, Williams \& Nyvall (1980) avaliaram plantas da cultivar Corsoy, inoculadas a campo com cada patógeno ou com ambos em combinação. A porcentagem de tecido foliar infectado foi maior para plantas inoculadas com S. glycines (65-78\%), seguida por plantas inoculadas com os dois patógenos (60-69\%), e menor para plantas inoculadas com P. glycinea (46-62\%). A produção foi reduzida em parcelas inoculadas quando comparadas com as parcelas não inoculadas, com redução média na produtividade pela inoculação de $S$. glycines e $P$. glycinea de 17,4 \% e 17,9\%, respectivamente, e de $14,1 \%$ quando inoculados juntos. A produção foi altamente correlacionada com a porcentagem de tecido foliar infectado por S. glycines $(\mathrm{r}=-0,95 ; \mathrm{P}=0,01)$, moderadamente correlacionado para $P$. glycinea $(\mathrm{r}=-0,73$; $\mathrm{P}=0,01)$ e não correlacionado para parcelas inoculadas com os dois patógenos $(\mathrm{r}=-0,61$; $\mathrm{P}=0,10)$. Observou-se, também, que a produção estava associada com o nível de desfolha das plantas da parcela, sendo que as parcelas inoculadas com S. glycines foram as que apresentaram maior índice de desfolha nas plantas.

\subsubsection{Resistência genética}

Apesar de vários autores usarem o termo resistência, é possível observar que o patógeno encontra condições adequadas e favoráveis na espécie Glycine max, sendo difícil encontrar plantas altamente resistentes. Kamicker \& Lim (1985) relataram em um estudo nos Estados Unidos, que em mais de 7.000 linhagens de um banco de germoplasma (USDA-ARS Northern Soybean Germplasm Collection), não se encontrou 
nenhuma fonte de resistência à mancha parda, sendo que todas foram consideradas suscetíveis em avaliações realizadas no estádio R6. Young \& Ross (1978) não conseguiram encontrar plantas imunes ou com alta resistência a este patógeno, em 626 diferentes plântulas em casa-de-vegetação e em plantas já granadas no campo.

Se esses trabalhos mostram a dificuldade na busca de resistência, indicam, também, que uma alternativa a ser seguida no controle desta doença é a busca de plantas tolerantes. Bernard (1989) afirmou que, aparentemente, não existem diferenças significativas na reação a essa doença entre cultivares de soja. No entanto, Lim (1979), Yorinori (1987b, 1992) e Cooper (1989), afirmaram que existem diferenças significativas quanto à severidade da doença entre genótipos. Isso mostra a necessidade de pesquisas com o objetivo de encontrar plantas tolerantes, ou seja, aquelas que apesar de infectadas não apresentem redução significativa de produtividade.

Apesar do conhecimento da existência de alguns genótipos tolerantes, até o momento, poucos estudos foram desenvolvidos com relação ao controle genético da soja à mancha parda (Brogin et al., 2003b). Portanto, há necessidade de se obter mais informações sobre os mecanismos de resistência genética e, também, identificar os QTLs (Quantitative Trait Loci) envolvidos na expressão do caráter, utilizando técnicas de biologia molecular. Com isso, os programas de melhoramento podem ser melhor direcionados, gerando materiais mais promissores, pois variabilidade existe, mas deve ser melhor explorada (Brogin, 2001).

\subsubsection{Ferrugem asiática da soja (Phakopsora pachyrhizi)}

\subsubsection{Agente causador}

A ferrugem asiática da soja, causada pelo fungo Phakopsora pachyrhizi Syd. \& Syd., foi constatada pela primeira vez no Brasil em 2001, sendo motivo de grande preocupação devido a sua importância e alto potencial de danos nos países asiáticos. A 
ocorrência desta doença foi verificada em quase todos os países tropicais e subtropicais, onde ela parece ser endêmica.

Por vários anos presumiu-se que a ferrugem da soja era causada somente por $P$. pachyrhizi, mas alguns trabalhos indicaram que os isolados asiáticos-australianos e os americanos diferiam genetica e patologicamente. Bonde \& Brown (1980) encontraram diferenças na reação de isolados americanos e asiáticos na cultivar de soja Wayne, mas o tamanho do uredósporo, forma e distribuição de poros germinativos eram indistinguíveis entre os isolados. Recentemente, uma nova espécie denominada Phakopsora meibomiae foi designada para a ferrugem da soja nas Américas, diferindo de P. pachyrhizi no número de camadas do teliósporo, cor e espessura das paredes do teliósporo, tamanho do uredósporo e número de poros germinativos (Quadro 2). Não eram somente duas espécies morfologicamente distintas, mas também geograficamente separadas (Ono et al., 1992).

\begin{tabular}{|c|c|c|c|c|c|}
\hline \multirow[b]{2}{*}{ Espécie } & \multirow{2}{*}{$\begin{array}{c}\text { Camadas } \\
\text { dos } \\
\text { teliosporos }\end{array}$} & \multicolumn{2}{|c|}{ Parede do teliosporo } & \multicolumn{2}{|c|}{ Uredosporos } \\
\hline & & Cor & $\begin{array}{c}\text { Espessura } \\
(\mu \mathrm{m})\end{array}$ & $\begin{array}{l}\text { Diâmetro } \\
(\mu \mathrm{m})\end{array}$ & $\begin{array}{c}\text { Poros } \\
\text { germinativos }\end{array}$ \\
\hline meibomiae & $1-5$ & $\begin{array}{l}\text { canela a } \\
\text { castanho }\end{array}$ & $1,5-2,0$ a 6,0 & $16-31 \times 12-24$ & $4-6$ \\
\hline pachyrhizi & $2-7$ & $\begin{array}{c}\text { amarelo escuro } \\
\text { a hialino }\end{array}$ & 1,0 & $18-34 \times 15-24$ & $6-8$ \\
\hline
\end{tabular}

Quadro 2. Características morfológicas de P. meibomiae e P. pachyrhizi, agentes causais da ferrugem da soja nas Américas e Austro-Ásia, respectivamente. (Ono et al., 1992)

\subsubsection{Sintomatologia}

A doença manifesta-se de forma irregular, dependendo das condições ambientais como umidade e temperatura. O sintoma da doença é caracterizado por pequenos pontos com menos de $1 \mathrm{~mm}$ de diâmetro, de coloração pardo-avermelhada, na parte superior das folhas. As lesões podem coalescer em infecções severas, formando grandes manchas castanhas, causando o amarelecimento e queda prematura das folhas. 
Nas fases iniciais do desenvolvimento, esta doença pode ser confundida com a septoriose, uma das doenças do "complexo de doenças de final de ciclo" da soja, causada pelo fungo Septoria glycines Hemmi. Porém, difere desta por apresentar coloração mais avermelhada e pela ausência de halo amarelado ao redor da lesão. $\mathrm{Na}$ parte inferior da folha, a lesão é de coloração castanho-clara a castanho-escura, tendo uma pequena elevação no centro, de coloração mais clara. Esta parte mais clara do centro constitui a cutícula que cobre a massa de uredósporos produzida no interior do tecido da folha. Segundo Hartman et al. (1997), a ferrugem asiática da soja ocorre em folhas como lesões palha (TAN) a marrom escuro ou marrom avermelhado (RB) com uma ou muitas urédias erumpentes, globosas e estioladas. As lesões TAN caracterizam genótipos suscetíveis à ferrugem, enquanto que as lesões RB (reddish-brown), caracterizam a reação de resistência dos genótipos.

\subsubsection{Hospedeiros alternativos}

Phakopsora pachyrhizi e Phakopsora meibomiae têm uma ampla gama de hospedeiros, a qual inclui a soja cultivada (Glycine max), outras espécies do gênero Glycine e outros gêneros dentro da família das leguminosas. Ono et al. (1992) encontraram P. meibomiae em 19 gêneros e 42 espécies, com 12 gêneros e 18 espécies adicionais confirmados serem hospedeiros após inoculação artificial; e, $P$. pachyrhizi em 17 gêneros e 31 espécies, com 28 gêneros e 60 espécies adicionais hospedeiras, confirmadas após inoculação (Quadro 3). As princiapis espécies infectadas a campo por P. meibomiae são Aeschynomene americana, Crotalaria spp., Desmodium spp., Lablab purpureus, Neonotonia wightii, Phaseolus coccineus, Phaseolus lunatus e Phaseolus vulgaris, sendo que as principais espécies identificadas como hospedeiras de $P$. pachyrhizi a campo são Glycine max, Glycine soja, Pachyrhizus erosus, Pueraria labata e Vigna unguiculata. 
Algumas outras espécies onde o fungo foi encontrado foram Teramnus uncinatus, Macroptilium lathyroides, Vigna lutea e Pachyrhizus bulbosus (Vakili, 1979; Bromfield, 1974; do Vale et al., 1985b).

\begin{tabular}{|c|c|c|c|c|}
\hline \multirow{2}{*}{ Espécie } & \multicolumn{2}{|c|}{ Infectados a Campo } & \multicolumn{2}{|c|}{ Inoculados Artificialmente } \\
\hline & Gêneros & Espécies & Gêneros & Espécies \\
\hline P. meibomiae & 19 & 42 & 12 & 18 \\
\hline P. pachyrhizi & 17 & 31 & 26 & 60 \\
\hline
\end{tabular}

Quadro 3. Número de gêneros e espécies reportados como hospedeiros de P. meibomiae e P. pachyrhizi sob condições de campo e inoculação artificial (Ono et al., 1992)

\subsubsection{Danos e perdas causados pelo patógeno}

As ferrugens provocam constantemente enormes perdas em várias culturas, principalmente em gramíneas, como trigo, cevada, milho e cana. Além das gramíneas, causam redução da produtividade também em soja, café, feijão, ornamentais, frutíferas e hortícolas (Bedendo, 1995).

Reduções significativas na produtividade de soja causadas pela ferrugem asiática, têm sido reportadas na maioria dos países Sul e Sudeste-Asiáticos e Austrália. A doença também tem sido reportada na África, América Central, América do Sul e Caribe. Quase todos os países tropicais e subtropicais têm verificado a ocorrência de ferrugem; nestes países, essa doença parece ser endêmica em soja e outros hospedeiros (Hartman et al., 1997).

Perdas na produtividade variando de $10 \%$ a $80 \%$ foram verificadas a partir de dados experimentais em muitos países asiáticos e na Austrália. Essas perdas são atribuídas a P. pachyrhizi, enquanto dados de pequenas perdas têm sido verificados nas Américas devido a P. meibomiae. A magnitude das perdas na produtividade e efeitos adversos nos componentes de produtividade têm sido correlacionados com o início da 
doença em relação ao estádio de crescimento do hospedeiro (Ogle et al., 1979). Sob condições controladas, a ferrugem mostrou reduzir o número de vagens cheias, sementes por vagem e peso médio da semente (Melching et al., 1989).

No Brasil, na safra 2002/2003, a doença atingiu mais intensamente o estado da Bahia, causando um prejuízo de R \$ 300 milhões, afetando 30\% da produção do Estado, que caiu para 1,4 milhão de toneladas. Perdas de até $90 \%$ ocorreram em algumas propriedades onde a doença ocorreu com alta severidade (Yorinori, 2004). Na safra 2003/04 também ocorreram muitas perdas devido à presença desse patógeno; considerando-se o custo com o controle da doença e a redução da produtividade, foram calculados prejuízos de mais de US\$ 3 milhões. (Yorinori, 2004).

\subsubsection{Resistência genética}

Uma medida de controle econômico e efetivo da ferrugem é a obtenção de cultivares com alta resistência e produtividade. Para tanto, é necessário avaliar o germoplasma disponível e cruzar acessos resistentes com cultivares de soja com alta produtividade para desenvolver variedades resistentes com caracteres produtivos desejáveis (Tan et al., 1983). Com o aparecimento da ferrugem asiática no Brasil foram realizados testes para identificação de fontes de resistência, tendo sido testados genótipos já identificados como fontes de resistência em outros países e, também, o germoplasma de soja adaptado às condições brasileiras (Brogin et al., 2003a). Foram identificados alguns genótipos resistentes dentre os avaliados e, entre eles, as cultivares de soja FT-2 e BRS-134.

Existem quatro genes dominantes independentes identificados até o momento: Rpp1 (PI 200492), Rpp2 (PI 230970), Rpp3 (PI 462312) e Rpp4 (PI 459025) (Bromfield \& Hartwig, 1980; Hartwig \& Bromfield, 1983; McLean \& Byth, 1980; Hartwig, 1986). Além disso, as linhagens de soja, Tainung \#4, PI 459024 e PI 459025 e uma linhagem de G. soja (PI 339871) parecem ter genes específicos adicionais para resistência (Hartwig \& Bromfield, 1983; McLean \& Byth, 1980). 
Progressos consideráveis têm sido obtidos com relação aos estudos sobre a resistência específica. McLean \& Byth (1980) mostraram que o gene de resistência dominante presente na PI 200492 e em Tainung \#3 e Tainung \#4 era o mesmo. No entanto, visto que PI 200492 e Tainung \#3 eram suscetíveis a uma nova raça de ferrugem, mas Tainung \#4 era resistente, foi sugerido que havia um gene ou genes adicionais para resistência em Tainung \#4. O gene de resistência na PI 200492 foi designado Rpp1 (McLean \& Byth, 1980). Outro gene de resistência foi identificado na PI 230970 e PI 230971 por Bromfield \& Hartwig (1980).

Estudos adicionais realizados por Hartwig \& Bromfield (1983) identificaram um gene dominante para resistência na PI 462312 (Ankur) e elucidaram a inter-relação entre os genes específicos de resistência nas cultivares Ankur, PI 200492 e PI 230970. Cada cultivar carregava um gene dominante diferente para resistência e estes genes estavam localizados em locos diferentes. As designações dos genes de resistência nas três cultivares correspondem a Rpp1, Rpp2 e Rpp3, respectivamente na PI 200492, PI 230970 e PI 462312. Além destes três genes de resistência, um quarto gene foi identificado por Hartwig (1986), sendo denominado Rpp4.

Genes para resistência à ferrugem são também observados entre as espécies perenes selvagens do gênero Glycine. Acessos de G. clandestina, G. canescens, G. tabacina e G. tomentella foram avaliados como altamente resistentes e são considerados como fontes potenciais de genes de resistência para transferência para a soja cultivada, uma vez que cruzamentos interespecíficos são possíveis (Burdon \& Marshall, 1981; Burdon, 1988; Schoen et al., 1992).

Dados de um estudo realizado pelo Asian Vegetable Research and Development Center (AVRDC) - Taiwan em 1985, sugerem que as raças predominantes de ferrugem são complexas e estas raças possuem fatores de virulência múltiplos para compatibilidade na maioria das linhagens. A presença destas raças complexas limitaria a efetividade da resistência específica e, portanto, haveria a necessidade de se identificar e caracterizar outras formas de resistência ou tolerância que possam minimizar as perdas provocadas pela ferrugem (Tschanz \& Shanmugasundaram, 1984). De acordo com Tschanz et al. (1985) técnicas como rotação e piramidação de genes de resistência 
específicos serão provavelmente inefetivas, devido a esta característica da patógeno. No entanto, Kilen (1997) realizou um trabalho com o objetivo de transferir o gene Rpp4 da linhagem PI 459025 para um genótipo melhor adaptado, obtendo uma linhagem com níveis satisfatórios de produtividade e resistência.

Linhagens com resistência parcial foram identificadas e caracterizadas baseando-se no período latente e no número de uredinias por lesão ou em linhagens com desenvolvimento lento da ferrugem (Hartman et al., 1991; Tschanz et al., 1980; Zambolim et al., 1983). Um impedimento principal para o desenvolvimento de linhagens com reduzida taxa de desenvolvimento da doença têm sido a dificuldade de se avaliar genótipos de populações segregantes ou de acessos com diferentes períodos de maturação. Além das diferenças fisiológicas, há diferenças nas condições ambientais, pois as plantas amadurecem em diferentes períodos de tempo.

As dificuldades associadas com a identificação e quantificação da resistência do tipo taxa reduzida de desenvolvimento da doença e a inefetividade da resistência raçaespecífica direcionou a avaliação da soja para tolerância à ferrugem (Tschanz \& Tsai, 1983). Tolerância é definida como a habilidade relativa de produção das plantas com ferrugem. Para avaliar a produção relativa, utiliza-se comparações entre a mesma linhagem plantada em uma parcela protegida por fungicida, com plantas da parcela não protegida. Um esquema de melhoramento para incorporar tolerância à ferrugem envolve avanço de gerações precoces através do métodos de populações (bulk) ou método da descendência de semente única (SSD) para características agronômicas, avanço de gerações intermediárias para seleção para tolerância à ferrugem com sementes colhidas em bulk dentro de famílias e, avanço de gerações finais para seleção para taxa reduzida de desenvolvimento da doença, tolerância e características agronômicas (Tschanz et al., 1985). 


\subsection{Marcadores moleculares}

Antes do início da utilização de técnicas moleculares para a detecção de variabilidade genética com base na seqüência de DNA, os marcadores morfológicos eram muito utilizados para estudos genéticos tais como ligação gênica e, também, para a construção de mapas genéticos. No entanto, a probabilidade de associações significativas entre marcadores morfológicos e caracteres agronomicamente importantes era reduzida, devido ao pequeno número desses marcadores em uma mesma linhagem, tornando seu uso limitado (Ferreira \& Grattapaglia, 1998; Guimarães \& Moreira, 1999).

Atualmente, diversas técnicas de biologia molecular estão disponíveis para a detecção de polimorfismo genético em várias espécies de plantas, o que não ocorria com os marcadores morfológicos, que se restringiam a poucas espécies de plantas utilizadas como sistemas modelo para estudos genéticos, tais como milho, tomate e ervilha, nas quais a disponibilidade de informações genéticas eram maiores.

São muitas as aplicações dos marcadores moleculares em plantas, sendo principalmente utilizados em análises de diversidade genética, na caracterização de germoplasma e no mapeamento de genes e QTLs de interesse (Lande \& Thompson, 1990; Thompson \& Nelson, 1998; Reyna \& Sneller, 2001; Yuan et al., 2002; Cornelious \& Sneller, 2002; Webb et al., 1995; Chang et al., 1996; Chang et al., 1997; Concibido et al., 1997; Meksem et al., 1999).

Há vários tipos de marcadores moleculares disponíveis para estudos genéticos, sendo que os mais utilizados são as Isoenzimas, o RFLP, o RAPD, o AFLP e os microssatélites (SSR)

\subsubsection{Isoenzimas}

Isoenzimas são definidas como um grupo de múltiplas formas moleculares de uma mesma enzima que ocorre em uma espécie, como resultado da presença de mais de um gene codificando cada uma das enzimas (Moss, 1982). A disseminação da utilização 
de marcadores genéticos em estudos dde genética e melhoramento iniciou-se com o desenvolvimento dos marcadores isoenzimáticos.

Os marcadores isoenzimáticos, de expressão codominante, são utilizados principalmente em estudos de variabilidade genética de populações naturais, fluxo gênico entre populações, filogenias, identificação de variedades, introgressão gênica e avaliação de germoplasma (Ferreira \& Grattaplaglia, 1998). No entanto, além das vantagens de utilização desses marcadores para os estudos genéticos antes citados, há também desvantagens, sendo uma delas a limitação de uso em estudos para construção de mapas genéticos saturados, o que dificulta a identificação de associação significativa entre os marcadores e caracteres de interesse agronômico, principalmente os que são poligênicos, ou seja, de herança quantitativa.

Em soja, atualmente, uma das importantes aplicações das isoenzimas tem sido verificada em estudos relacionados à lipoxigenase (Fischer et al., 1999; SkrzypczakJankun et al., 1997; Kariapper et al., 2001).

\subsubsection{Polimorfismo no comprimento de fragmentos de restrição (RFLP)}

Os marcadores RFLP (Restriction Fragment Lenght Polymorphism), identificam polimorfismos no comprimento de fragmentos, obtidos por corte da fita dupla de DNA utilizando enzimas de restrição e observados por hibridização dos fragmentos com seqüências marcadas radioativamente ou por compostos que desencadeiam luminescência (Ferreira \& Grattapaglia, 1998). O polimorfismo é gerado pela ausência ou presença dos sítios de clivagem das enzimas de restrição, os quais são constituídos de quatro a oito pares de base. As diferenças também podem resultar de inserções, deleções, translocações e/ou inversões, que alteram a distância entre os sítios de restrição.

Dentre as vantagens de utilização desses marcadores, está o potencial de cobertura de todo o genoma, aumentando a probabilidade de associações destes marcadores a genes que controlam um caráter de interesse. Além disso, são marcadores 
codominantes e atuam em regiões transcritas e não transcritas do DNA. Porém, a técnica utilizada é muito trabalhosa e requer uma biblioteca de sondas para hibridização. Outra dificuldade existente é a utilização de material radioativo, que exige estrutura adequada e pessoal apto a trabalhar com radioatividade.

Esses marcadores são muito utilizados no melhoramento, como também em estudos de sintenia entre diferentes espécies, visando estudar a conservação na ordem relativa de locos no cromossomo.

\subsubsection{Polimorfismo de DNA amplificado ao acaso (RAPD)}

Em 1990, com o desenvolvimento da técnica de RAPD (Random Amplified Polymorphic DNA) (Williams et al., 1990; Welsh \& McClelland, 1990), ocorreu um grande avanço na área de marcadores moleculares baseados em PCR, pois surgiu a idéia de se utilizar primers mais curtos e de seqüência arbitrária nas reações de amplificação, o que torna a seqüência alvo desconhecida.

O RAPD é uma variação da técnica de PCR, diferindo desta por utilizar apenas um primer. Para que haja amplificação de um fragmento, duas seqüências de DNA complementares ao primer arbitrário devem estar adjacentes e em orientação oposta. Cada um desses primers arbitrários dirige a síntese de vários segmentos diferentes de DNA, de vários pontos do genoma, resultando em várias bandas no gel. Os marcadores RAPD se comportam como marcadores genéticos dominantes, pois ao se observar uma banda no gel, não é possível distinguir se o segmento amplificado é originário de uma ou de duas cópias da seqüência amplificada.

Uma das fontes do polimorfismo gerado quando se utiliza essa técnica pode advir de mutações de ponto nos sítios de reconhecimento dos primers. Além disso, as deleções desses sítios de iniciação faz com que a DNA polimerase seja incapaz de amplificar segmentos longos de DNA, levando a uma interpretação binária dos resultados, ou seja, o segmento amplificado está presente ou ausente no gel. 
Os marcadores RAPD são utilizados para a obtenção de impressãoes digitais (fingerprints) genômicas de indivíduos, cultivares e populações; análise da estrutura e diversidade genética (Li \& Nelson, 2001; Thompson et al., 1998; Thompson \& Nelson, 1998); estudos de filogenia; e, construção de mapas genéticos de alta cobertura genômica e localização de genes de interesse econômico (Ferreira et al., 2000, MacGregor et al., 2002). No entanto, esses marcadores possuem algumas limitações, sendo uma delas o baixo conteúdo de informação genética por loco, inviabilizando estudos genéticos quando há necessidade de se identificar os genótipos heterozigóticos.

\subsubsection{Polimorfismo de comprimento de fragmentos amplificados (AFLP)}

A técnica do AFLP (Amplified Fragment Lenght Polymorphism) foi desenvolvida por Zabeau \& Vos (1993) e vem sendo muito utilizada para a obtenção de um grande número de marcadores moleculares distribuídos em genomas de eucariotos e procariotos. Para a análise de AFLP são realizadas quatro etapas: clivagem do DNA genômico total com duas enzimas de restrição, sendo uma de corte raro e uma de corte freqüente, uma de cada vez; ligação de adaptadores específicos aos terminais dos fragmentos genômicos gerados pela clivagem; amplificação seletiva de uma fração dos fragmentos via PCR utilizando primers específicos para reconhecer seqüências nos adaptadores; e, separação da subpopulação de fragmentos em gel de alta resolução (Ferreira \& Grattapaglia, 1998).

A análise de AFLP vem sendo utilizada de forma crescente para finalidades de impressão digital genômica (fingerprinting), mapeamento genético localizado (Bulk Segregant Analysis - BSA) e construção de mapas genéticos, principalmente em espécies de plantas cultivadas que apresentam uma baixa taxa de polimorfismo de DNA (Ferreira \& Grattapaglia, 1998).

Os marcadores AFLP, da mesma forma que os marcadores RAPD, se comportam como marcadores genéticos dominantes, ou seja, não é possível identificar diretamente os genótipos heterozigóticos. 


\subsubsection{Marcadores baseados na amplificação de microssatélites (SSR)}

No genoma dos organismos eucariontes existem muitas seqüências repetitivas de DNA que se localizam em regiões de micro e mini-satélites. Nas drosófilas, por exemplo, $30 \%$ do genoma é formado por este tipo de seqüência; no arroz, 50\%; e no tabaco chega a 70\% (Lewin, 2001). Uma dessas classes consiste na repetição em tandem de dois a cinco nucleotídeos, denominados microssatélites, ou Simple SequenceRepeats (SSR). A seqüência de DNA que flanqueia essas regiões contendo repetições curtas são conservadas dentro de uma espécie, permitindo a seleção de primers de PCR que podem ser utilizados para amplificar os SSRs. Após amplificação dessas regiões específicas, o polimorfismo no tamanho dos fragmentos obtidos é devido ao número diferente de repetições das seqüências simples. Os microssatélites são marcadores codominantes e multialélicos, fornecendo um elevado nível de informação genética por loco.

Os marcadores microssatélites tornaram-se rapidamente os mais utilizados pelos geneticistas de humanos, para o desenvolvimento de mapas de ligação e para a identificação de indivíduos. Em plantas, os microssatélites são muito freqüentes e distribuídos ao acaso ao longo do genoma, também sendo amplamente utilizados nos estudos de diversidade genética, caracterização de germoplasma, construção de mapas genéticos e mapeamentos de genes e QTLs.

Em soja, os marcadores microssatélites têm sido muito utilizados para o mapeamento de genes específicos que determinam características agronomicamente importantes e, também, para a identificação de QTLs de importância econômica envolvidos na produtividade de grãos e na resistência genética a pragas e doenças, que são características de herança complexa (Webb et al., 1995; Chang et al., 1996; Mansur et al., 1996; Concibido et al., 1997; Njiti et al., 1997; Meksem et al., 1999; Mian et al., 1999; Arahana et al., 2001; Bachman et al., 2001; Schuster et al., 2001; Yang et al., 2001; Yuan et al., 2002). 


\subsection{Construção de mapas genéticos}

O mapeamento genético teve início após o reconhecimento do fenômeno da ligação genética (Morgan, 1910). Antes do material genético ser denominado DNA, já foram construídos os primeiros mapas genéticos de espécies cultivadas (MacArthur, 1934). O mapeamento genético toma como base a hipótese de que a co-segregação de dois marcadores indica proximidade entre eles, e que a probabilidade de ocorrer permutas genéticas entre esses dois marcadores é menor, quanto menor for a distância entre eles. Dessa forma, é possível ordenar linearmente a informação genética ao longo dos cromossomos. A grande disponibilidade de marcadores moleculares e metodologias estatísticas eficientes fizeram com que, atualmente, estejam disponíveis mapas genéticos saturados para a maioria das espécies cultivadas.

A probabilidade de ocorrência de permuta genética entre dois marcadores, ou freqüência de recombinação, reflete a distância genética entre os locos. A distância de mapeamento, expressa em centiMorgans (cM), é calculada com base na freqüência de recombinação por meio de funções de mapeamento, as quais corrigem as distorções entre a conversão das unidades. A função de Haldane é a mais simples e admite que as permutas genéticas ocorrem ao acaso e são independentes. A função de Kosambi considera interferência parcial nos cálculos da distância em centiMorgans, sendo que essa interferência significa que uma permuta genética afeta a ocorrência de outras em regiões adjacentes, considerando a ocorrência de permutas duplas.

Um marcador deve ser polimórfico entre os indivíduos parentais e apresentar uma segregação mendeliana esperada na progênie para ser utilizado no mapeamento genético. O número de marcadores necessário para construir um mapa genético depende do tamanho do genoma, do número de cromossomos e da freqüência de recombinação genética. Um mapa pode ser considerado completo, quando o número de grupos de ligação obtidos pela análise dos marcadores for igual ao número de cromossomos gaméticos do organismo ou quando todos os marcadores genéticos mapeados estiverem ligados, sugerindo que todas as regiões do genoma estão representadas. 
Não há uma relação geral entre a distância genética e a distância física, existindo uma grande variação entre organismos e dentro de um mesmo cromossomo. A quantidade de DNA correspondente a um centiMorgan pode variar de $140 \mathrm{~kb}(1 \mathrm{~kb}=$ 1.000 pares de base) em Arabdopsis, a $2.000 \mathrm{~kb}$ em milho (Lynch \& Walsh, 1997). Embora a distância genética seja altamente variável, a ordem dos marcadores ao longo dos grupos de ligação e a distância entre locos em diferentes espécies são extremamente conservadas (Paterson, 1996). Tal fato sugere que regiões contendo DNA repetitivo são uma das principais causas da grande diferença no tamanho físico do genoma das plantas superiores.

\subsection{Marcadores moleculares vs. mapeamento de genes e QTLs envolvidos na resistência de plantas a doenças}

A identificação de marcadores moleculares ligados a genes e QTLs de resistência pode ser de grande utilidade para o processo de melhoramento de uma determinada espécie. A primeira etapa da identificação de marcadores é a escolha correta dos genitores para cruzamento e obtenção de uma geração segregante $\left(\mathrm{F}_{2}, \mathrm{~F}_{3}\right.$, retrocruzamento, linhagens recombinantes). Esses genitores devem ser divergentes para o caráter, ou seja, devem apresentar reações distintas a um determinado patógeno. A próxima etapa é a detecção de marcadores moleculares polimórficos entre os genitores resistente e suscetível, analisandose posteriormente as segregações destes e da resistência em uma população segregante. $\mathrm{O}$ princípio básico da análise é a partição da população em classes genotípicas para cada loco marcador e, através de testes estatísticos, determinar se há diferença entre os indivíduos das diferentes classes quanto à característica quantitativa mensurada. Os marcadores fortemente ligados ao gene de resistência co-segregam com a resistência.

Algumas características quantitativas que mostram uma distribuição contínua em uma população segregante são controladas, na grande maioria dos casos, por um número pequeno de locos. A análise genética utilizando marcadores moleculares e mapas de ligação pode elucidar o número e a localização desses locos que controlam características 
quantitativas, denominados Quantitative Trait Loci (QTLs). Portanto, o termo QTL designa uma região do cromossomo, definida pela ligação a um marcador molecular, que tem um efeito significativo sobre uma característica quantitativa (Tanksley, 1993). Se um pequeno número de QTLs (1-3) explicar grande parte da variância fenotípica, a característica pode ser trabalhada como se fosse qualitativa, utilizando seleção assistida por marcadores.

Os procedimentos mais simples para a detecção de associações entre marcadores e o caráter em questão são os modelos de regressão linear e análise de variância, que analisam a distribuição dos valores fenotípicos para cada marcador, separadamente. Esta metodologia é relativamente simples e não requer a construção de mapas genéticos, mas não permite a identificação da posição do QTL e não estima a magnitude do seu efeito.

Como alternativa para aumentar o poder de detecção das associações e, para estimar o efeito e a posição dos QTLs, o uso do mapeamento por intervalo, proposto por Lander \& Botstein (1989) tem sido muito utilizado. Essa metodologia utiliza o método da máxima verossimilhança para estimar a posição mais provável e a magnitude do QTL no intervalo entre dois marcadores ligados no mapa genético (Lynch \& Walsh, 1997). No entanto, é uma metodologia mais complexa, que requer a construção de mapas genéticos. Novos modelos têm sido propostos para aumentar a resolução do mapeamento de QTLs, como o mapeamento por intervalo composto (Zeng, 1994), múltiplos QTLs (Jansen, 1993) e o mapeamento por intervalos múltiplos (Kao et al., 1999). 


\section{MARCADORES MICROSSATÉLITES FLANQUEANDO UM GENE DOMINANTE DE RESISTÊNCIA À FERRUGEM ASIÁTICA DA SOJA}

\section{Resumo}

A ferrugem asiática da soja, causada pelo fungo Phakopsora pachyrhizi é uma importante doença da soja em várias regiões do mundo. Atualmente tem causado grandes perdas em produtividade nos principais países produtores. O objetivo desse trabalho foi identificar marcadores microssatélites ligados a um gene para resistência a $P$. pachyrhizi presente na cultivar de soja FT-2, utilizando uma população de plantas $F_{2}$ derivada do cruzamento entre as cultivares FT-2 (resistente) e Davis (suscetível). Aproximadamente 260 marcadores microssatélites foram testados nos genitores, sendo os polimórficos utilizados para genotipar as plantas da geração $F_{2}$, que foi inoculada e avaliada para resistência/suscetibilidade à ferrugem. Foram detectados cinco marcadores SSR associados à resistência à ferrugem, sendo que dois deles (Satt079 e Satt307) flanqueiam o gene dominante de resistência, que foi mapeado no grupo de ligação C2 da soja. Uma eficiência de seleção de $100 \%$ foi obtida com o uso simultâneo destes dois últimos marcadores, indicando que os mesmos podem ser ferramentas úteis para a seleção assistida de genótipos homozigóticos resistentes.

Palavras-chave: Glycine max, Phakopsora pachyrhizi, SSR, seleção assistida. 


\section{Molecular markers flanking a dominant gene to Asian soybean rust resistance}

\section{Summary}

The Asian soybean rust, caused by the fungus Phakopsora pachyrhizi is an important disease in soybeans worldwide and causes severe yield lost in the main soybean producing countries. The main of this work was to identify SSR markers linked to a resistance gene present in the soybean cultivar FT-2 using an $\mathrm{F}_{2}$ mapping population originated from the cross between FT-2 (resistant) and Davis (susceptible). The parental genotypes were screened with about 260 SSR markers and the polymorphic ones were used to genotype the plants of the $F_{2}$ mapping population, that were selfed to generate the $F_{3: 2}$ and $F_{4: 2}$ progenies. The plants of that progenies were inoculated and scored to soybean rust resistance/susceptibility. Five markers were detected in the mapping population associated to the rust reaction and two of them (Satt079 and Satt307) were found flanking the dominant resistance gene that was mapped in the soybean linkage group C2. A selection efficience of $100 \%$ was obtained with the simultaneous use of both markers and so they can be usefull toll to marker assisted selection of homozygous resistant genotypes making easier and faster the selective process of that gene in any segregant population.

Keywords: Glycine max; Phakopsora pachyrhizi; microssatélites; SSR; marker-assisted selection. 


\subsection{Introdução}

A produtividade e a estabilidade das cultivares atuais de soja, desenvolvidas através de melhoramento genético, são características muito importantes para a aceitação comercial por parte dos produtores. Dentre os fatores que garantem a estabilidade dessas cultivares, está a resistência genética a doenças, que é o método de controle mais eficiente e econômico para os produtores e mais adequado às práticas de conservação do ambiente.

Mais de 40 doenças afetam a cultura da soja em todo o mundo, causando grandes perdas em produtividade nos principais países produtores do grão (Wrather et al., 1997). A ferrugem asiática da soja, causada pelo fungo Phakopsora pachyrhizi, tem sido verificada nos hemisférios oriental e ocidental, incluindo a África, representando uma grande ameaça para os países do continente americano. Essa doença já causa grandes perdas em muitos países, principalmente no continente asiático (Bromfield \& Yang 1976; Hartman et al., 1999), e vem causando perdas também no Brasil. Desde sua primeira constatação no País, na safra de 2001/2002, foram registradas perdas de até $80 \%$, principalmente nos estados da Bahia e Mato Grosso. Na safra 2002/03, as perdas de grãos foram estimadas em 3,442 milhões de toneladas, ou o equivalente a US\$758,868 milhões. Já na safra 2003/04 a ferrugem asiática provocou perdas de cerca de 4,5 milhões de toneladas de soja; associando o que deixou de ser colhido aos gastos com o controle químico (fungicidas e despesas com aplicação), o custo ferrugem foi de aproximadamente US\$ 2 bilhões (Yorinori, 2004). Atualmente, o único método de controle utilizado é o químico com fungicidas, pois não existem cultivares resistentes disponíveis no mercado.

Com o aparecimento da doença no Brasil, o programa de melhoramento da Embrapa Soja (Londrina, PR, Brasil) mobilizou esforços para a identificação de fontes de resistência para a raça, ou raças predominates do patógeno, com o objetivo de desenvolver cultivares resistentes (Brogin et al. 2003a). Muitas das fontes de resistência identificadas eram introduções de plantas (PIs), as quais não são adaptadas às condições edafoclimáticas do país. No entanto, a cultivar FT-2, recomendada para cultivo durante 
muitos anos no Brasil, foi identificada como sendo resistente nas avaliações e provavelmente possui um dos genes de resistência vertical já identificados em outros genótipos (Bromfield \& Hartwig 1980; McLean \& Byth 1980; Hartwig \& Bromfield 1983; Hartwig 1986). Há também a possibilidade desta cultivar possuir um outro gene de resistência, diferente dos identificados até o momento.

Desde o início dos anos 80, os marcadores moleculares vêm sendo amplamente utilizados como ferramenta no melhoramento de várias culturas de interesse econômico, e entre elas está a soja. Até o momento, vários genes e QTLs envolvidos na resistência aos principais patógenos da soja foram mapeados, o que tem contribuído para a melhoria da eficiência dos programas de melhoramento e, para um melhor entendimento das bases moleculares da resistência às diversas doenças.

Visto que os recursos aplicados em um programa de melhoramento genético são relativamente altos, devido principalmente às avaliações extensivas dos genótipos, há necessidade de criação de estratégias para aumentar sua eficiência. De acordo com Tanksley et al. (1993), os melhoristas podem utilizar marcadores moleculares para selecionar indiretamente indivíduos em uma população segregante que carrega um gene de interesse, se existir uma ligação forte entre o loco marcador e o gene que controla o caráter. Além disso, se houver a presença de dois locos marcadores flanqueando o gene de interesse o processo torna-se mais eficiente (Young \& Tanksley, 1989). Marcadores fortemente ligados a genes de resistência podem auxiliar muito os programas de melhoramento visando resistência a doenças, permitindo seguir o gene sob seleção através das gerações, ao invés da avaliação da expressão fenotípica do gene de resistência. Esses marcadores podem ser utilizados no processo de seleção assistida por marcadores (SAM), permitindo também que vários genes sejam agrupados em um mesmo genótipo (piramidação de genes de resistência). Adicionalmente, os marcadores podem ser úteis para a clonagem e seqüenciamento desses genes de resistência em associação com outras ferramentas moleculares, como as bibliotecas genômicas.

Com o aparecimento desse novo desafio para a cultura que é a ferrugem da soja, a seleção de genótipos assistida por marcadores moleculares ligados aos vários genes de resistência será de grande utilidade, já que se trata de um patógeno que 
apresenta grande capacidade de gerar novas raças a cada ano agrícola. Com isso, a busca por fontes de resistência deverá ser contínua e o monitoramento dos diversos genes de resistência nos genótipos será fundamental para o desenvolvimento de cultivares com resistência satisfatória.

Para a ferrugem da soja, poucos trabalhos de identificação de marcadores moleculares para genes de resistência foram desenvolvidos (Chunwongse et al., 2004) e, assim, o objetivo desse trabalho foi identificar marcadores moleculares ligados ao gene de resistência à ferrugem asiática da soja, presente na cultivar FT-2.

\subsection{Material e métodos}

\subsubsection{Material genético}

Todas as etapas experimentais foram realizadas na Embrapa Soja (Londrina, PR, Brasil). Em 1998 foi realizado um cruzamento entre a cultivar de soja FT-2, tolerante à mancha parda (Septoria glycines), uma doença de final de ciclo da soja, e a cultivar suscetível Davis. As plantas $F_{1}$ foram cultivadas em casa-de-vegetação e colhidas em 1999, sucedendo-se uma nova semeadura para obtenção de progênies $F_{3: 2}$ a partir de 116 plantas $F_{2}$. As progênies $F_{3: 2}$ foram utilizadas no ano de 2000, em um experimento para estudo da genética da resistência da soja a S. glycines (Brogin, 2001; Brogin et al., 2003b). As plantas foram colhidas para dar origem a 116 famílias $\mathrm{F}_{4: 2}$. Com o aparecimento da ferrugem asiática da soja (Phakopsora pachyrhizi) no Brasil, testes iniciais identificaram a cultivar FT-2 como uma fonte de resistência (Brogin et al., 2003a), de maneira que as 116 famílias $F_{4: 2}$ do cruzamento entre as cultivares FT-2 e Davis também foram avaliadas para reação à ferrugem da soja. 


\subsubsection{Delineamento experimental e instalação do experimento}

O experimento foi instalado em casa-de-vegetação com temperatura controlada, variando de $20^{\circ} \mathrm{C}$ a $28^{\circ} \mathrm{C}$. Doze indivíduos de cada genótipo parental (FT-2 e Davis) e 116 famílias $\mathrm{F}_{4: 2}$, representadas por 12 indivíduos cada uma, foram casualizados no experimento, sob delineamento inteiramente casualizado, sendo a parcela constituída de uma planta.

A semeadura foi realizada em vasos com $20 \mathrm{~cm}$ de diâmetro e $25 \mathrm{~cm}$ de altura, contendo cerca de 4,5 $\mathrm{kg}$ de uma mistura de solo, areia e esterco bovino, esterilizado com brometo de metila. Em cada vaso foram mantidas três plantas, sendo dois genótipos integrantes do experimento e a cultivar Davis, que foi utilizada como padrão de suscetibilidade para o monitoramento da ocorrência da ferrugem no ambiente de realização do experimento.

\subsubsection{Preparo do inóculo e inoculação das plantas com Phakopsora pachyrhizi}

Como o agente causador da ferrugem da soja é um parasita obrigatório, a população do patógeno foi mantida em plantas suscetíveis de soja em casa-de-vegetação, para uso em experimentos conforme a demanda. O procedimento para o preparo do inóculo consistiu na coleta de folhas infectadas e retirada dos esporos (uredósporos) utilizando pincel esterilizado e água destilada. Após a obtenção da suspensão com os esporos, foi realizada a contagem dos mesmos em câmara de contagem de células (Neubauer) e a diluição, para obtenção da concentração de $3 \times 10^{5}$ esporos $/ \mathrm{mL}$. À solução final, foi adicionado o espalhante adesivo Tween 20 na proporção de $0,5 \mathrm{~mL} / \mathrm{L}$ de solução.

As plantas foram inoculadas quando atingiram o estádio V3-V4 de crescimento (trifólio completamente desenvolvido acima do segundo ou terceiro nó), de acordo com a escala proposta por Fehr \& Caviness (1981). A inoculação das plantas, utilizando-se pulverizador manual, foi realizada ao anoitecer para evitar a inviabilização dos 
uredosporos pela falta de água livre nas folhas e baixa umidade do ambiente, causados pelas temperaturas mais altas na casa-de-vegetação durante os horários de maior insolação. Após doze horas da inoculação, foram realizadas, durante 48 horas, aspersões constantes de água a cada hora, com duração de 15 segundos, para manter a quantidade necessária de água livre na superfície das folhas, fornecendo as condições ideais para o desenvolvimento do patógeno (Sinclair \& Hartman, 1996).

\subsubsection{Avaliação fenotípica dos genitores e famílias $F_{4: 2}$}

A reação das plantas à ferrugem da soja foi verificada em um experimento realizado em casa-de-vegetação no ano de 2003. Plantas resistentes e suscetíveis são facilmente discriminadas pelas reações típicas de cada caso. Lesões RB (Reddish Brown) são características de genótipos resistentes e lesões TAN caracterizam os genótipos suscetíveis. Portanto, a avaliação realizada foi unicamente qualitativa, classificando cada uma das 116 progênies $F_{4: 2}$ como homozigótica resistente, heterozigótica ou homozigótica suscetível.

\subsubsection{Coleta de tecido foliar}

As amostras de tecido foliar das plantas $F_{2}$ que deram origem às progênies $F_{4: 2}$ foram coletadas no ano de 1999 e mantidas em ultrafreezer $\left(-80^{\circ} \mathrm{C}\right)$ até o momento da extração de DNA. Cada uma das amostras consistia de duas folhas recém expandidas, coletadas de plantas em estádios iniciais de crescimento (V1-V2; folha primária ou trifólio completamente desenvolvido a partir do nó unifoliolado, de acordo com a escala de Fehr \& Caviness, 1981). 


\subsubsection{Extração de DNA}

A extração de DNA dos genótipos parentais e dos indivíduos da geração $F_{2}$ foi realizada com base no procedimento descrito por Keim et al. (1988), com algumas modificações. Aproximadamente um grama de tecido foliar congelado foi pulverizado utilizando-se almofariz, procedendo-se à transferência de uma pequena parte da amostra para microtubos com capacidade para $1,5 \mathrm{~mL}$ e adição de tampão de extração na proporção de quatro vezes o volume da amostra [100 mM tris, $\mathrm{pH} 8,0,1,4 \mathrm{M} \mathrm{NaCl}, 20$ $\mathrm{mM}$ EDTA, 1\% (m/v) brometo de trimetil N-cetil amônio (CTAB), 0,1\% (v/v) 2mercaptoetanol]. A suspensão foi incubada a $65^{\circ} \mathrm{C}$ por 60 minutos, com agitação a cada 15 minutos. Após a incubação, as amostras foram centrifugadas a $6000 \mathrm{rpm}$ por 10 minutos, com transferência da fase aquosa para outro microtubo. Adicionou-se igual volume de clorofórmio-álcool isoamílico (24:1), procedendo-se à mistura por inversões e centrifugação a $6000 \mathrm{rpm}$ por 15 minutos. Estes últimos passos foram repetidos. O DNA foi precipitado com a adição de isopropanol (2/3 do volume) e, posteriormente, a solução foi centrifugada a $14000 \mathrm{rpm}$ por 10 minutos, descartando-se o sobrenadante e adicionando-se $0,5 \mathrm{~mL}$ de etanol $70 \%$. Realizou-se uma nova centrifugação e descarte do sobrenadante, para diluição do DNA precipitado em $0,4 \mathrm{~mL}$ de $10 \mathrm{mM}$ tris/1 mM EDTA, pH 8,0. Para finalizar, foi adicionada a enzima RNAseA na proporção de 40 $\mu \mathrm{g} / \mathrm{mL}$, com incubação a $37^{\circ} \mathrm{C}$ por pelo menos 30 minutos.

Após a extração do DNA das folhas de soja, foi realizada sua quantificação, determinada por análise espectrofotométrica, por leitura de absorbância a $260 \mathrm{~nm}$ e 280 $\mathrm{nm}$, considerando que cada unidade de leitura a $260 \mathrm{~nm}$ corresponde à concentração de $50 \mu \mathrm{g} / \mathrm{mL}$ de DNA de fita dupla (Sambrook et al., 1989). Após determinada a concentração de DNA, as amostras foram diluídas utilizando água milliQ, para uma concentração final de $10 \mathrm{ng} / \mu \mathrm{L}$. 


\subsubsection{Amplificação de locos microssatélites e visualização dos fragmentos}

O polimorfismo entre os genótipos parentais FT-2 e Davis foi verificado com o teste de marcadores de microssatélites distribuídos nos 20 grupos de ligação da soja (Cregan et al., 1999; Song et al., 2004). Inicialmente foram testados os marcadores citados em trabalhos de mapeamento de genes e QTLs envolvidos na resistência a doenças em soja pois, de acordo com vários autores, genes que conferem resistência a um único patógeno ou a patógenos taxonomicamente diferentes foram mapeados em “clusters" no genoma da soja (Diers et al., 1992; Kanazin et al., 1996; Polzin et al., 1994; Yu et al., 1994). No entanto, como ainda há poucos trabalhos de mapeamento de genes de resistência à ferrugem da soja, nenhum grupo de ligação específico foi alvo de maior atenção.

Como os 116 indivíduos da geração $F_{2}$ foram representados e caracterizados pelas respectivas progênies $F_{4: 2}$ na avaliação fenotípica, foram selecionados 11 indivíduos $\mathrm{F}_{2}$ homozigóticos resistentes e 11 indivíduos $\mathrm{F}_{2}$ homozigóticos suscetíveis à ferrugem para, ao invés de fazerem parte de um "bulk" de DNA, serem genotipados individualmente com os marcadores que apresentaram polimorfismo entre os genitores. Após verificação de uma provável ligação dos marcadores ao caráter devido a diferenças nos alelos presentes em cada um dos grupos (resistente ou suscetível), estes foram utilizados para a genotipagem do restante dos indivíduos da população de plantas $\mathrm{F}_{2}$.

A amplificação dos locos microssatélites foi realizada de acordo com a metodologia descrita por Akkaya et al. (1995), com modificações. As reações de PCR foram compostas de $10 \mathrm{mM}$ Tris, $\mathrm{pH} 8,5,50 \mathrm{mM} \mathrm{KCl}, 1,5 \mathrm{mM} \mathrm{Mg}^{2+}, 130 \mu \mathrm{M}$ de dNTPs, 0,2 $\mu \mathrm{M}$ de cada "primer", 30 ng de DNA genômico, 1 unidade de Taq DNA polimerase, em um volume total de $10 \mu \mathrm{L}$. As condições de amplificação consistiram de um período inicial de desnaturação do DNA de um minuto a $94^{\circ} \mathrm{C}$, seguido de 35 ciclos térmicos, com cada um deles incluindo as etapas de desnaturação do DNA por 35 segundos a $94^{\circ} \mathrm{C}$, anelamento dos primers por 35 segundos a $55^{\circ} \mathrm{C}$ e extensão por 35 segundos a $72^{\circ} \mathrm{C}$. Após os ciclos térmicos, um período final de extensão de um minuto a $72^{\circ} \mathrm{C}$ foi realizado. A eletroforese dos fragmentos amplificados foi realizada em géis de 
poliacrilamida $10 \%$ (29:1 acrilamida:bisacrilamida). Os géis foram corados com brometo de etídio, visualizados sob luz ultravioleta e a captação de imagens foi realizada utilizando o sistema digital Kodak de fotodocumentação.

\subsubsection{Análise de ligação}

Após obtidos os resultados das avaliações da reação das famílias $F_{4: 2}$ à ferrugem, que caracterizaram as plantas $\mathrm{F}_{2}$ em homozigóticas resistentes, heterozigóticas e homozigóticas suscetíveis, foi realizado o teste de conformidade do modelo $\left(\chi^{2}\right)$ para verificar se a segregação observada do loco que confere resistência (Rpp) corresponde à proporção de 1RppRpp:2Rpprpp:1rpprpp ou, se a proporção não for evidente, se a segregação observada corresponde à esperada $3 \mathrm{Rpp} \_$: 1 rpprpp ou $1 \mathrm{Rpp}$ _:3rpprpp. O mesmo teste também foi realizado para determinar se a segregação genotípica dos marcadores microssatélites testados nas plantas da população de mapeamento $F_{2}$ diferia da proporção esperada de 1:2:1. Marcadores que não se adequaram às segregações esperadas não foram utilizados para a análise de ligação.

A codificação utilizada para caracterizar a reação fenotípica dos indivíduos da geração $F_{2}$ foi a mesma utilizada após a genotipagem dos indivíduos com os marcadores microssatélites, ou seja, a reação fenotípica foi codificada como um marcador molecular e mapeada como uma característica qualitativa. O programa Mapmaker/EXP 3.0 (Lander et al., 1987) foi utilizado para a realização da análise de ligação, com opção da função de mapeamento de Kosambi, com distância máxima de 37,2 centimorgans. 


\subsection{Resultados e discussão}

\subsubsection{Avaliação fenotípica}

As primeiras lesões causadas pelo patógeno nas folhas, com urédias em plena esporulação, foram observadas dez dias após a inoculação. No entanto, a avaliação fenotípica dos genitores e das famílias $\mathrm{F}_{4: 2}$ foi realizada aos 15 dias após a inoculação, quando todas as plantas da cultivar padrão de suscetibilidade (cv. Davis), presente em todos os vasos do experimento, apresentaram lesões TAN em plena esporulação. A cultivar FT-2 apresentou somente lesões do tipo RB (Reddish Brown), características de genótipos resistentes à ferrugem; a cultivar Davis, altamente suscetível, apresentou somente lesões do tipo TAN.

Das 116 progênies $\mathrm{F}_{4: 2}, 42$ delas foram caracterizadas como sendo RppRpp (homozigóticas resistentes), 50 Rpprpp (heterozigóticas) e 24 rpprpp (homozigóticas suscetíveis). Portanto, considerando as plantas $\mathrm{F}_{2}$ que deram origem a essas progênies, 92 foram identificadas como sendo resistentes e 24 suscetíveis. Essa proporção observada foi testada para verificar a conformidade com a proporção mendeliana esperada de 3:1. O valor de qui-quadrado $\left(\chi^{2}\right)$ obtido de $1,149(\mathrm{P}=0,284)$ indica que a proporção observada não foi significantemente diferente do modelo genético esperado. Portanto, nesse cruzamento em estudo, a resistência envolve dominância completa. Esse resultado está de acordo com os já publicados que tratam da herança da resistência à ferrugem da soja, os quais identificam quatro genes com ação dominante para resistência (Bromfield \& Hartwig, 1980; Hartwig \& Bromfield, 1983; McLean \& Byth, 1980; Hartwig, 1986).

\subsubsection{Análise dos marcadores SSR e mapeamento}

Para identificar marcadores microssatélites associados ao gene de resistência à ferrugem em soja presente na cultivar FT-2 que poderiam ser utilizados em programas 
de melhoramento, foram testados aproximadamente 260 marcadores SSR para verificar o polimorfismo entre os genótipos parentais FT-2 e Davis, tendo sido identificados 41 polimórficos. O baixo polimorfismo obtido pode ser atribuído à base genética estreita da soja cultivada e ao fato das cultivares utilizadas nesse estudo possuírem em suas genealogias genótipos ancestrais comuns (Hiromoto \& Vello, 1986; Bonato \& Bonato, 1987). As constituições genéticas dessas cultivares estão apresentadas na Tabela 1.

Tabela 1. Constituição genética das cultivares de soja Davis e FT-2, utilizadas como genitores

\begin{tabular}{ccc}
\multicolumn{2}{c}{ Constituição Genética } \\
\hline Cultivar & $1 / 8 \mathrm{~A}+1 / 4 \mathrm{~B}+3 / 16 \mathrm{C}+3 / 16 \mathrm{E}+1 / 4 \mathrm{~F}$ \\
FT-2 & $1 / 8 \mathrm{~A}+1 / 4 \mathrm{~B}+1 / 8 \mathrm{C}+1 / 8 \mathrm{D}+1 / 8 \mathrm{E}+1 / 8 \mathrm{G}+1 / 8 \mathrm{H}$ \\
Letra Símbolo & Identificação & Origem \\
\hline A & CNS (provavelmente PI 71597) & Sul da China \\
B & Roanoke (Nanking) & Nanking, China \\
C & Tokyo (PI 8424) & Yokohama, Japão \\
D & S-100 (Illini ou A.K.3) & Nordeste da China \\
E & PI 54610 & Nordeste da China \\
F & PI 37335 (Arksoy) & Pingyang, Coréia \\
G & PI 36846 (Dunfield) & Nordeste da China \\
H & PI 6396 (Haberlandt) & Pingyang, Coréia \\
\hline
\end{tabular}

Após realizada a genotipagem dos indivíduos selecionados da geração $\mathrm{F}_{2}$, com base na avaliação fenotípica das respectivas famílias $\mathrm{F}_{4: 2}$ (11 homozigóticos resistentes e 11 homozigóticos suscetíveis), utilizando os marcadores que apresentaram polimorfismo entre os genótipos parentais, verificou-se a ligação putativa de cinco deles, pertencentes ao grupo de ligação C2, relacionados ao caráter: Satt 277, Satt, 307, Staga001, Sat_263 e Satt079. Esses marcadores foram utilizados para a genotipagem de todas as outras 
plantas da população de mapeamento $F_{2}$. Os marcadores Satt307 e Satt079 segregaram na população $F_{2}$ na proporção de 1:2:1 considerando um nível de significância de 5\%; os marcadores Satt277, Sat_263 e Staga001 também segregaram de acordo com esta proporção considerando um nível de significância de 1\% (Tabela 2).

Tabela 2. Distribuição das progênies $\mathrm{F}_{4: 2}$ do cruzamento FT-2 x Davis inoculadas com Phakopsora pachyrhizi e distribuição dos dados de genotipagem das plantas $\mathrm{F}_{2}$ que originaram as progênies $\mathrm{F}_{4: 2}$

\begin{tabular}{ccccccc}
\hline & \multicolumn{3}{c}{ Reação à Ferrugem } & \multicolumn{2}{c}{ Teste qui-quadrado $\left(\chi^{2}\right)$} \\
Cruzamento/Marcador & $\mathrm{N}$ & $\mathrm{R}$ & $\mathrm{R} / \mathrm{S}$ & $\mathrm{S}$ & Segregação & Probabilidade \\
\hline FT-2 x Davis & 116 & 42 & 50 & 24 & $3: 1$ & 0,284 \\
Sat_263 & 115 & 35 & 64 & 16 & $1: 2: 1$ & 0,021 \\
Satt079 & 114 & 39 & 52 & 23 & $1: 2: 1$ & 0,068 \\
Satt277 & 115 & 40 & 57 & 18 & $1: 2: 1$ & 0,015 \\
Satt307 & 116 & 36 & 56 & 24 & $1: 2: 1$ & 0,270 \\
Staga001 & 109 & 39 & 53 & 17 & $1: 2: 1$ & 0,011 \\
\hline
\end{tabular}

${ }^{1} \mathrm{R}$ : resistente, S: suscetível

A alta porcentagem de alelos marcadores da cultivar FT-2 (resistente) em homozigose nessa população provavelmente não foi um evento aleatório pois, mesmo não sendo realizada nenhuma seleção intencional, outros eventos de seleção podem ter ocorrido naturalmente. Além da possibilidade de erros na genotipagem da população de mapeamento devido a bandas duplicadas, uma explicação para esse fato poderia ser a hipótese de segregação distorcida dos marcadores na região do genoma em estudo, a favor do genótipo homozigótico da cultivar FT-2. Segundo Vogl \& Xu (2000), regiões cromossômicas que causam proporções distorcidas na segregação podem ser referidas como sendo locos de segregação distorcida (LSD). Essas distorções são causadas pela representação diferencial dos genótipos LSD nos gametas antes da fertilização ou por diferenças na viabilidade dos genótipos LSD após a fertilização mas antes da seleção do genótipo. Em ambos os casos, o fenótipo observado é uma distorção do genótipo de determinado loco em regiões cromossômicas próximas a locos de segregação distorcida. Em várias regiões genômicas de diferentes espécies de plantas foram identificados locos 
apresentando segregações distorcidas (Yamanaka et al., 2001; Xu et al., 1997). Kato \& Palmer (2003), estudando um mutante esporofítico e mutantes gametofíticos responsáveis pela esterilidade parcial feminina em soja, mapearam genes expressos no esporófito no grupo de ligação C2 da soja, em região próxima ao marcador Satt079, utilizado nesse estudo. Esse fato pode estar influenciando a segregação dos locos marcadores e também do gene de resistência à ferrugem pois, em todos os casos, o genótipo homozigótico da cultivar FT-2 foi favorecido.

A análise de ligação utilizando o programa Mapmaker/EXP 3.0 (Lander et al., 1987), com valor mínimo de LOD de 3,0, resultou no mapeamento do gene de resistência à ferrugem da soja (Rpp) no grupo de ligação C2 da soja (Cregan et al., 1999), a 7,6 cM do marcador Satt079 e a 9,7 cM do marcador Satt307, os quais estão flanqueando o gene de resistência. Os demais marcadores também foram mapeados no mesmo grupo de ligação (Figura 1).

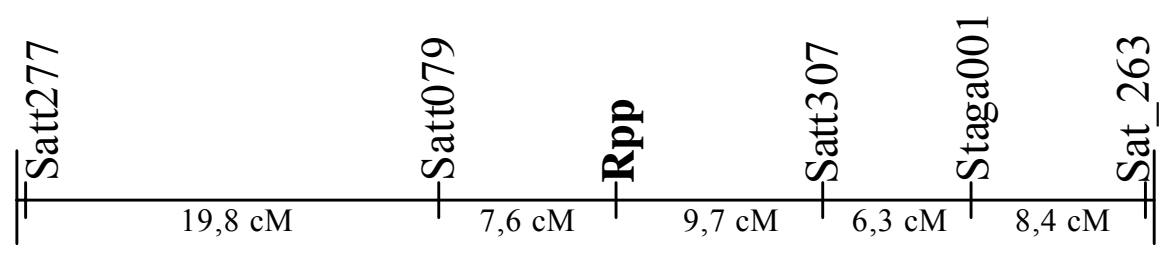

Figura 1. Representação gráfica parcial do grupo de ligação $\mathrm{C} 2$ da soja, indicando o posicionamento do gene de resistência à ferrugem (Rpp) em relação aos marcadores SSR identificados.

Yamanaka et al. (2001) reportaram a presença de QTLs no grupo de ligação C2 associados à forma e tamanho de folíolos e também de um QTL envolvido na determinação da época de florescimento em soja, o qual está próximo do gene que define a coloração da pubescência e de um dos genes de florescimento e maturação (E1; 
mapa genético clássico da soja). Interessantemente, a incidência e a severidade da ferrugem são muito influenciadas pelo ciclo de desenvolvimento das cultivares. Alguns trabalhos relatam maiores severidades da doença e perdas na produtividade em linhagens e cultivares mais tardias do que nas mais precoces (Manandhar \& Joshi, 1983; Vale et al., 1985a, Kawuki et al., 2004). Além disso, em condições naturais de infecção, o florescimento é determinado como o momento crítico para o aparecimento dos primeiros sintomas e o desenvolvimento mais rápido do patógeno (Yorinori, 2004; Embrapa, 2005). Ainda não existem dados concretos que comprovem a hipótese mas se acredita que, por se tratar de um patógeno foliar biotrófico, quando a planta inicia o período reprodutivo, ou seja, começa a florescer, suas energias são direcionadas para o desenvolvimento das vagens e sementes, fazendo com que o patógeno se desenvolva rapidamente para produzir grande quantidade de esporos, que são disseminados para outras plantas, garantindo a sua sobrevivência.

Comparando-se a ordem dos marcadores obtida por Cregan et al. 1999 e por Song et al. 2004 com a ordem dos marcadores obtida nesse trabalho no grupo de ligação C2, observou-se a inversão dos marcadores Satt307, Staga001 e Sat_263 no presente trabalho. De acordo com os mapas de ligação obtidos nos trabalhos citados anteriormente, o marcador Sat_263 estaria mais próximo ao gene de resistência à ferrugem. De acordo com Frisch et al. 2004, a segregação distorcida também pode ser causada por locos duplicados, podendo interferir até mesmo na ordem dos marcadores no mapeamento. Portanto, pode ser que na região do genoma em estudo existam locos marcadores duplicados, fato que explicaria tanto a ordem incorreta dos marcadores no mapa de ligação, como também a ocorrência de segregação distorcida.

\subsubsection{Utilidade dos marcadores identificados para seleção assistida}

Em soja, o controle de patógenos através da resistência genética é uma prática muito útil e a maioria das resistências utilizadas é monogênica e dominante. Até o momento, o melhoramento da cultura da soja tem gerado cultivares com resistência a 
pelo menos dez patógenos (cancro da haste - Diaporthe phaseolorum, mancha olho-derã - Cercospora sojina, pústula bacteriana - Xanthomonas campestris pv. glycines, crestamento bacteriano - Pseudomonas savastanoi pv. glycinea, oídio - Microsphaera diffusa, nematóides - Heterodera glycines e Meloidogyne sp., podridão parda da haste Phialophora gregata, podridão da haste e raiz - Phytophtora sojae, vírus da necrose da haste - carlavirus, Vírus do mosaico comum da soja - SMV), ainda que com estabilidade e níveis de expressão variáveis.

No caso específico da ferrugem da soja, embora o melhoramento convencional tenha um impacto significativo no melhoramento para resistência a essa doença de recente detecção em lavouras brasileiras, o processo trabalhoso de realizar cruzamentos e retrocruzamentos, e a seleção das progênies resistentes desejadas, dificultam o rápido desenvolvimento de novas cultivares resistentes em resposta à evolução de novas raças patogênicas. Além disso, os testes de diagnóstico para as raças são de difícil aplicação devido ao desafio imposto pela manutenção e produção isolada do inóculo.

A eficiência de seleção para resistência à ferrugem utilizando genótipos homozigóticos para um ou dois marcadores está apresentado na Tabela 3. Para Sat_263, Satt079, Satt277, Satt307 e Staga001 isoladamente, as eficiências de seleção foram de $91,43 \%, 89,74 \%, 77,50 \%, 88,89 \%$ e $87,18 \%$, respectivamente. A maior eficiência individual de seleção obtida foi com a utilização do marcador Sat_263 (91,43\%), que está a 24,4 cM do gene de resistência. Os marcadores Satt307 e Staga001, que foram mapeados mais próximos ao gene, apresentaram eficiências de seleção menores que Sat_263, de 88,89\% e 87,18\%, respectivamente. Esse fato reforça a hipótese da ordem incorreta dos marcadores obtida no mapeamento dos marcadores nesse trabalho, que pode estar sendo causada por locos marcadores duplicados. No caso do marcador Satt277, observou-se a relação da menor eficiência de seleção com a distância em relação ao gene de resistência. 
Tabela 3. Eficiência de seleção para resistência à ferrugem asiática da soja na população de mapeamento $\mathrm{F}_{2}$ considerando um, dois ou três marcadores SSR homozigóticos para o alelo presente na cultivar FT-2

\begin{tabular}{lcc}
\hline Marcadores & $\begin{array}{c}\text { Plantas resistentes } \\
\text { selecionadas }\end{array}$ & Eficiência de seleção (\%) \\
\hline Sat_263 & 32 & 91,43 \\
Satt079 & 35 & 89,74 \\
Satt277 & 31 & 77,50 \\
Satt307 & 32 & 88,89 \\
Staga001 & 34 & 87,18 \\
Satt079+ Satt307 & 30 & 100,00 \\
\hline
\end{tabular}

No entanto, de acordo com os dados obtidos nesse trabalho, a seleção de plantas homozigóticas utilizando os marcadores Satt079 e Satt307, que estão flanqueando o gene de resistência, resultou na mais alta e total eficiência de seleção (100\%). Portanto, a utilização destes marcadores para a seleção assistida é válida, pois identifica os genótipos homozigóticos e o gene de resistência pode ser fixado em poucos ciclos de seleção.Porém, estudos adicionais são requeridos para melhor exploração da região do genoma onde o gene de resistênia se encontra.

\subsection{Conclusões}

Mesmo com a identificação de marcadores flanqueando o gene de resistência à ferrugem no grupo de ligação C2 (Satt079 e Satt307) e a demonstração da eficiência de seleção total dos genótipos homozigóticos resistentes por estes marcadores, se faz necessária a identificação de outros marcadores mais próximos ao gene para utilização segura no processo de seleção assistida. Marcadores mais próximos também possibilitariam a exploração de bibliotecas genômicas de soja, com a identificação de clones YAC (Yeast Artificial Chromosome) ou BAC (Bacterial Artificial Chromosome) contendo o gene de resistência à ferrugem. Dessa forma sua seqüência seria conhecida e 
marcadores específicos poderiam ser desenvolvidos e o gene poderia ser melhor estudado e comparado aos demais genes específicos de resistência.

É possível que na região do genoma que foi estudada nesse trabalho existam locos de segregação distorcida, pois tanto os locos marcadores como também o gene de resistência à ferrugem apresentaram segregação distorcida, com freqüências genotípicas do parental resistente à ferrugem sendo favorecida. Locos marcadores duplicados também podem estar ocorrendo. No entanto, estudos adicionais são necessários para confirmar essas hipóteses e explorar melhor essa região onde o gene de resistência à ferrugem está localizado. 


\section{MAPEAMENTO DE QTLS ENVOLVIDOS NA RESISTÊNCIA À SEPTORIOSE EM SOJA}

\section{Resumo}

A septoriose ou mancha parda da soja (causada por Septoria glycines Hemmi) é considerada uma doença fúngica importante, pois pode provocar grandes perdas na produtividade da soja. O objetivo deste trabalho foi identificar e determinar os efeitos de QTLs envolvidos na resistência à septoriose em soja. Foram avaliadas, para reação à doença, 116 progênies $\mathrm{F}_{3: 2}$ e $\mathrm{F}_{4: 2}$ oriundas do cruzamento entre as cultivares de soja FT-2 (resistente) e Davis (suscetível), em dois experimentos em casa-de-vegetação. Marcadores moleculares microssatélites (SSR) foram testados nos genótipos parentais, sendo os polimórficos utilizados para a genotipagem da população de plantas $F_{2} e$ construção do mapa genético. Análises de regressão e de variância foram realizadas para identificar associações significativas entre marcadores e QTLs devido a efeitos aditivos e não aditivos do caráter. Foi realizado, também, o mapeamento por intervalo dos QTLs. As análises de regressão detectaram maior número de marcadores ligados a QTLs do que o mapeamento por intervalo; houve concordância entre os resultados dos dois métodos em apenas um caso, no qual o marcador Satt277, pertencente ao grupo de ligação $\mathrm{C} 2$, foi relacionado significativamente ao caráter.

Palavras-chave: Glycine max; Septoria glycines; mancha parda; SSR. 


\section{Mapping QTLs involved in the resistance to soybean brown spot}

\section{Summary}

Brown spot (caused by Septoria glycines Hemmi) is considered an important fungal disease in soybeans because the yield loss it can cause. The objective of this study was to detect and determine the QTL effects involved in brown spot resistance. One hundred sixteen $F_{2: 3}$ and $F_{2: 4}$, originated from the cross between the soybean cultivars FT-2 (resistant) and Davis (susceptible), were evaluated for disease resistance in two greenhouse trials. SSR markers were tested in the parental genotypes and the polymorphic ones were used to screening the $\mathrm{F}_{2}$ plant population and to construct the linkage map. Regression analysys, ANOVAs and interval analysis detected significative associations between markers and QTLs explained by additive and non-additive effects of the traits. Regression analysis detected more markers linked to QTLs than the interval analysis; only the marker Satt277 (soybean linkage group C2) was significantly associated to the trait in the two methods.

Keywords: Glycine max; Septoria glycines; disease resistance; SSR. 


\subsection{Introdução}

Dentre as espécies vegetais cultivadas de maior importância econômica e social para o Brasil, a soja [Glycine max (L.) Merrill] é a que mais se destaca. A expansão do cultivo da soja no Brasil teve início no final da década de 60, tornando-se, em curto período de tempo, um dos principais produtos da exploração agrícola e da economia nacional. Desde o início da produção comercial até a safra de 2003/04, a área cultivada nacional aumentou de 702 para 21.284,1 mil hectares, a produção de 457 para 49.792,7 mil toneladas e a produtividade média de 651 para $2.339 \mathrm{Kg} / \mathrm{ha}$ (Bonato \& Bonato, 1987; CONAB, 2005). Esse aumento de produtividade, a qual seria maior caso não ocorressem problemas como falta de chuvas e doenças como a ferrugem asiática, juntamente com o aumento da área cultivada com o grão, contribuiu para colocar o Brasil como o segundo maior produtor mundial de soja, com estimativas de produção na safra 2004/05 de 50,2 milhões de toneladas.

Devido ao seu valor econômico e social e também ao melhoramento genético, que desenvolveu cultivares de soja adaptadas às mais diversas condições e mais resistentes às diversas pragas e doenças, houve uma rápido crescimento da cultura no Brasil nos últimos 30 anos. Atualmente, a contínua expansão da cultura da soja nas regiões dos cerrados, mais propícias ao desenvolvimento das doenças, e a importância dessas doenças na redução do rendimento de grãos, torna prioritária a seleção de genótipos tolerantes/resistentes e o desenvolvimento de novas cultivares para atender as necessidades crescentes dos produtores de reduzir os custos de produção.

A presença do fungo Septoria glycines Hemmi, agente causal da "mancha parda" da soja, foi relatado pela primeira vez nos Estados Unidos por Wolf e Lehman (1926), na Carolina do Norte. Entretanto, logo se tornou evidente que a doença em estudo era idêntica à descrita por Hemmi em 1915. No Brasil, o relato da ocorrência de mancha parda foi feito por Luzzardi et al. (1972), em Pelotas, no Estado do Rio Grande do Sul, em amostras de soja colhidas no ensaio de cultivares de soja do IPEAS. Essa doença ocorre na mesma época do crestamento foliar provocado pelo fungo Cercospora kikuchii e, devido às dificuldades que apresentam nas avaliações individuais, são 
consideradas como um "complexo de doenças de final de ciclo". Wrather et al. (1997), reunindo informações sobre as estimativas de perdas por doenças dos dez países com as maiores produções de soja no ano agrícola de 1994, concluíram que o nematóide de cisto da soja (Heterodera glycines), o cancro da haste (Diaporthe phaseolorum var. caulivora), a mancha parda (Septoria glycines) e a podridão negra (Macrophomina phaseolina) foram, entre outras doenças, em ordem de importância, os principais causadores de perdas na produção. Os mesmos autores também afirmaram que a mancha parda e o crestamento causado por Cercospora kikuchii são doenças responsáveis pela desfolha precoce e perdas anuais de aproximadamente $7 \%$ na produção em condições naturais. Outros trabalhos também reportam as perdas causadas por mancha parda (Pataky \& Lim, 1981; Williams \& Nyvall, 1980).

Grandes avanços na biologia molecular durante as últimas décadas contribuíram para o desenvolvimento de ferramentas moleculares aplicadas na análise genética de características de importância agronômica em plantas. Dentre essas ferramentas, destacam-se os marcadores moleculares, principalmente os baseados na amplificação do DNA via reação de polimerização em cadeia (PCR), como os polimorfismos de DNA amplificados ao acaso (RAPD) e os microssatélites, também denominados SSR (Single Sequence Repeats) (Williams et al., 1990). Essas metodologias fizeram com que fossem desenvolvidos em curto espaço de tempo mapas de ligação saturados em soja e em outras espécies, possibilitando o mapeamento de regiões cromossômicas contendo locos responsáveis por características quantitativas, denominadas QTLs (Quantitative Trait Loci). O mapeamento de QTLs contribui para o melhor entendimento do controle genético de características como resistência quantitativa de plantas a patógenos, pois a associação de marcadores moleculares a QTLs permite individualizar os efeitos fenotípicos de cada loco envolvido na resistência (Lander \& Botstein, 1989).

O objetivo desse trabalho foi mapear regiões genômicas envolvidas na resistência da soja a S. glycines e determinar os efeitos de cada QTL mapeado, visando o melhor entendimento das bases genéticas dessa resistência. 


\subsection{Material e Métodos}

\subsubsection{Material Genético}

\subsubsection{Genótipos parentais}

Uma das fases mais importantes de um programa de melhoramento é a escolha dos genitores para a realização dos cruzamentos, que objetivam combinar no mesmo indivíduo, qualidades que estão dispersas em indivíduos diferentes. A magnitude do ganho genético é diretamente proporcional à variabilidade genética disponível na população de plantas. Partindo-se de cultivares com performances agronômicas similares, os cruzamentos entre pares geneticamente mais distantes produzirão uma maior variância entre progênies, porque o número de locos segregantes é maximizado (Cox et al., 1985; Messmer et al., 1993). Nesse tipo de cruzamento, a probabilidade de obtenção de genótipos superiores será bem maior que a de um cruzamento envolvendo indivíduos produtivos e geneticamente similares.

Os genótipos parentais escolhidos para esse estudo foram FT-2 e Davis, considerados tolerante e suscetível à mancha parda, respectivamente. A caracterização dessas cultivares foi obtida através de avaliações em casa-de-vegetação, realizadas nas fases iniciais de desenvolvimento da soja e, também, com base em dados experimentais de avaliações realizadas no final do ciclo em condições de campo (Arias et al., 1999; Brogin et al., 1999; Brogin et al., 2003b). As sementes de cada um dos genótipos parentais foram obtidas de planta única para evitar que houvesse algum tipo de variação que comprometesse os resultados.

\subsubsection{Gerações Segregantes}

Os cruzamentos entre os genótipos parentais foram realizados em casa-devegetação nos meses de fevereiro e março de 1998. Esses cruzamentos foram colhidos 
após aproximadamente 90 a 100 dias, sendo semeados em dezembro de 1998 para obtenção de sementes $F_{2}$. Parte das sementes $F_{1}$ foi armazenada em câmara fria. Uma nova semeadura foi realizada no mês de abril de 1999 com as sementes $F_{1}$ remanescentes e $F_{2}$, além das linhagens parentais. Finalmente, o material genético disponível para experimentação foram sementes $F_{2}$ e sementes de 116 famílias $F_{3: 2}$, além de sementes dos genótipos parentais. Dessa forma, as sementes foram obtidas na mesma época, também para evitar algum tipo de variação entre as gerações.

Em outubro de 2001, foi realizado mais um avanço de geração, a partir de sementes das famílias $\mathrm{F}_{3: 2}$, para a obtenção das famílias $\mathrm{F}_{4: 2}$. A colheita foi realizada em fevereiro de 2002.

\subsubsection{Delineamento Experimental}

Os experimentos foram instalados na Área Experimental da Embrapa Soja, em casa-de-vegetação, com temperatura controlada, variando de $20^{\circ} \mathrm{C}$ a $28^{\circ} \mathrm{C}$, sob um delineamento inteiramente casualizado, sendo a parcela constituída de uma planta. A casualização, a lista de preparo dos materiais para semeadura e a caderneta de campo dos experimentos foram obtidas utilizando-se o programa SGQ (Sistema de Genética Quantitativa), desenvolvido na Embrapa Soja.

Nesse trabalho foram utilizados dados de avaliações de dois experimentos. No primeiro, foi avaliada a reação à mancha parda dos genótipos parentais (FT-2 e Davis) e a geração $F_{3: 2}$ resultante do cruzamento entre estes genótipos. Em um segundo experimento, a geração $F_{4: 2}$ foi avaliada juntamente com os genótipos parentais para reação à mancha parda.

No experimento em que a geração $F_{3: 2}$ foi avaliada, 20 indivíduos de cada genótipo parental faziam parte do experimento, além de 116 famílias $F_{3: 2}$ representadas por cinco indivíduos cada uma. Já no experimento em que foi avaliada a geração $F_{4: 2 \text {, }}$ dez indivíduos de cada genótipo parental e 116 famílias $F_{4: 2}$ representadas por seis indivíduos cada uma foram avaliados para reação à mancha parda. 
A semeadura foi realizada em vasos plásticos com $20 \mathrm{~cm}$ de diâmetro e $25 \mathrm{~cm}$ de altura, contendo cerca de $4,5 \mathrm{~kg}$ de uma mistura de solo e esterco bovino, esterilizado com brometo de metila. Os vasos foram dispostos em mesas com superfície de tela metálica, com capacidade para 34 vasos. Em cada vaso havia duas plantas integrantes do experimento, de acordo com a casualização, além de uma planta da cultivar Davis, que foi utilizada como testemunha padrão de suscetibilidade no momento da avaliação e, também, para corrigir a variação microambiental, entrando como covariável no modelo estatístico.

\subsubsection{Inóculo de Septoria glycines}

O inóculo inicial de Septoria glycines foi isolado de folhas infectadas da cultivar de soja FT-Estrela, obtidas a campo no ano de 1997, nas dependências da Embrapa Soja. Após cultivo em meio apropriado, foi obtido um isolado monospórico, com denominação 106/97, sendo integrado à coleção de isolados do Laboratório de Fitopatologia da Embrapa Soja. Desde o momento do isolamento do patógeno, não foi realizada a renovação do isolado através de inoculação em plantas de soja suscetíveis e re-isolamento. Portanto, para verificar sua virulência, o isolado foi testado em inoculações artificiais nos genótipos parentais antes da realização dos experimentos, para observação dos sintomas causados, nas mesmas condições a que os indivíduos dos experimentos seriam submetidos.

\subsubsection{Preparo do inóculo de Septoria glycines}

Após dez dias da data de semeadura de cada um dos experimentos, foram preparadas as placas de Petri contendo o patógeno em meio BDA (Batata-DextroseÁgar), suficientes para a obtenção da quantidade adequada de esporos para a inoculação. O preparo das placas foi feito adicionando-se água destilada e esterilizada a tubos de 
ensaio contendo a colônia do fungo em meio BDA, armazenados em câmara de crescimento (B.O.D) a $27^{\circ} \mathrm{C}$, e agitando-se levemente. Uma pequena quantidade da suspensão resultante de micélio e conídios foi vertida em placas de Petri contendo meio de cultura BDA e distribuída uniformemente sobre o meio, utilizando-se um pincel esterilizado, com posterior eliminação do excesso de líquido. Esse procedimento foi feito em câmara de fluxo contínuo esterilizada. As placas foram vedadas com filme plástico e mantidas em B.O.D. a $27^{\circ} \mathrm{C}$ com regime de doze horas de luz e doze horas de escuro por dez dias, período suficiente para que as colônias apresentem abundante esporulação, estando prontas para o preparo da suspensão que será utilizada na inoculação.

Para o preparo da suspensão inoculada foi adicionada uma pequena quantidade de água destilada às placas contendo o meio de cultura com a colônia do fungo e, utilizando-se um pincel, o micélio e os conídios do fungo foram retirados cuidadosamente. Para cada experimento foram preparados seis litros da suspensão de esporos e micélio, utilizando-se aproximadamente dez placas de Petri com as colônias bem desenvolvidas por litro de solução, para se obter a concentração de esporos de $5 \mathrm{x}$ $10^{6}$ esporos / $\mathrm{ml}$. Antes da diluição final da solução, foi realizada a contagem de esporos, utilizando-se a câmara de contagem de células de Neubauer. Obtido o valor da concentração de esporos, foi feita a diluição adequada para se obter a concentração final proposta acima. Após a diluição, foi realizada uma nova contagem de esporos do fungo, para verificar a concentração destes na solução final, à qual foi adicionado espalhante adesivo Tween 20 na proporção de $0,5 \mathrm{ml} /$ litro de solução.

\subsubsection{Inoculação}

A solução utilizada para a inoculação dos experimentos foi preparada pouco tempo antes da inoculação, para evitar a germinação dos esporos antes do contato com as plantas. As inoculações foram realizadas sempre no final da tarde, para evitar a inviabilização dos esporos pela falta de água livre nas folhas e baixa umidade do 
ambiente, causados pelas altas temperaturas da casa-de-vegetação durante os horários de maior insolação.

Foram utilizados pulverizadores manuais, aplicando-se o equivalente a $500 \mathrm{~mL}$ de suspensão / mesa contendo 34 vasos (aproximadamente $15 \mathrm{~mL}$ por vaso).

Doze horas após a inoculação, foram realizadas, durante 48 horas, aspersões constantes de água, a cada hora, com duração de quinze segundos para a manutenção da umidade do ambiente.

\subsubsection{Avaliações fenotípicas}

As avaliações foram realizadas sobre o primeiro, segundo e terceiro trifólios, no experimento em que a geração $F_{3: 2}$ foi avaliada e sobre o primeiro, segundo, terceiro e quarto trifólios no experimento no qual a geração $\mathrm{F}_{4: 2}$ foi avaliada, anotando-se o nível de infecção (NI) da doença nos diferentes trifólios, de acordo com uma escala de notas de 0 a 10, apresentadas no Quadro 1. A intensidade de amarelecimento dos trifólios avaliados também foi um parâmetro para a definição do nível de infecção da doença, contribuindo para aumentar as notas.

A reação (NI) da cultivar Davis, utilizada como testemunha padrão de suscetibilidade, foi considerada para a definição do momento correto da avaliação, no qual a diferença entre os níveis de infecção dos genótipos parentais FT-2 e Davis é máxima, permitindo uma melhor diferenciação das famílias genéticas resultantes do cruzamento entre os genótipos parentais quanto à reação ao patógeno, fator importante para as análises estatístico-genéticas realizadas (Brogin, 2001; Brogin, 2003b). 


\begin{tabular}{|c|c|c|}
\hline Nível de Infecção (NI) & \% Área Foliar Infectada & Amarelecimento \\
\hline 0 & 0 & - \\
\hline 1 & $<2$ & - \\
\hline 2 & 2 a 5 & - \\
\hline 3 & 5 a 10 & - \\
\hline 4 & 10 a 15 & - \\
\hline 5 & 15 a 20 & + \\
\hline 6 & 20 a 25 & + \\
\hline 7 & 25 a 30 & + \\
\hline 8 & 30 a 35 & + \\
\hline 9 & 35 a 40 & + \\
\hline 10 & $>40$ & 40 \\
\hline
\end{tabular}

Quadro 1. Escala de notas para o nível de infecção causado pelo patógeno Septoria glycines em folhas de soja, de acordo com a porcentagem de área foliar infectada e presença ou ausência de amarelecimento

\subsubsection{Análises estatísticas dos dados fenotípicos}

De posse dos dados das avaliações fenotípicas, foram obtidas as médias e variâncias de cada geração (Parental e $\mathrm{F}_{3: 2} / \mathrm{F}_{4: 2}$ ) e realizadas análises de variância para $\mathrm{o}$ caráter. Foram utilizados, para essas análises, os programas computacionais $\mathrm{SAS}^{\circledR}$ Sistema de Análises Estatísticas (SAS, 1999); SGQ - Sistema de Genética Quantitativa, desenvolvido na Embrapa Soja.

Utilizando dados da avaliação dos genótipos parentais de cada um dos experimentos, foram realizadas análises de variância com o objetivo de verificar diferenças entre os genótipos parentais, entre os trifólios avaliados e, também, se a interação genótipo parental x trifólio avaliado era significativa. O modelo dessa análise foi determinado por:

$$
Y_{i j}=\mu+p_{i}+f_{j}+(p f)_{i j}+e_{i j}
$$

sendo $\mathrm{Y}_{\mathrm{ij}}$ corresponde à média da j-ésima folha, do i-ésimo parental; $\mu$ é a média geral do experimento; $\mathrm{p}_{\mathrm{i}}$ é o efeito do i-ésimo genótipo parental; $\mathrm{f}_{\mathrm{j}}$ é o efeito da j-ésima folha; $(\mathrm{pf})_{\mathrm{ij}}$ é o efeito da interação entre o i-ésimo parental e a j-ésima folha; e, e $\mathrm{e}_{\mathrm{ij}}$ é o erro 
experimental. Neste caso, todos os efeitos foram considerados fixos, exceto o erro experimental.

Como em cada um dos vasos utilizados no experimento havia uma planta da cultivar padrão Davis, e sendo este um genótipo homogêneo distribuído por todo o experimento, foram realizadas análises de covariância utilizando a metodologia apresentada por Federer (1965) e Steel \& Torrie (1960), citada por Vencovsky e Barriga (1992). A significância da covariável no modelo para cada geração foi obtida e, em caso de significância, os coeficientes de regressão para cada geração foram utilizados para a correção dos dados para a covariável. Com a introdução da covariável no modelo, a variância é reduzida, aumentando-se a precisão das estimativas dos parâmetros do modelo. O modelo de covariância é descrito por:

$$
Y_{i j k}=\mu+g_{i}+\beta\left(x_{i j k}-\bar{x}\right)+e_{i j}
$$

sendo $\mathrm{Y}_{\mathrm{ijk}} \mathrm{o}$ valor do k-ésimo indivíduo, da j-ésima família, na i-ésima geração; $\mu$ é a média geral do experimento; gi é o efeito da i-ésima geração; $\beta$ é o parâmetro de regressão linear; $\mathrm{x}_{\mathrm{ijk}}$ é o valor da covariável do k-ésimo indivíduo, na j-ésima família, da i-ésima geração; $\bar{x}$ é a média geral da covariável no experimento; e, $\mathrm{e}_{\mathrm{ijk}}$ é o erro experimental.

Como já mencionado, após a realização da análise, caso a covariável seja significativa no modelo, a correção de cada um dos dados individualmente é feita pela equação:

$$
Y_{i j k}=y_{i j k}-\beta\left(x_{i j k}-\bar{x}\right)
$$

sendo $\mathrm{y}_{\mathrm{ijk}} \mathrm{o}$ valor estimado da nota para o nível de infecção no trifólio do k-ésimo indivíduo, na j-ésima família, da i-ésima geração, após a correção para a covariável; $\mathrm{y}_{\mathrm{ijk}}$ é a nota designada na avaliação para o nível de infecção no trifólio do k-ésimo indivíduo, na j-ésima família, da i-ésima geração; $\beta$ é o parâmetro de regressão 
estimado; $\mathrm{x}_{\mathrm{ijk}}$ é o valor da covariável correspondente ao k-ésimo indivíduo, na j-ésima família, da i-ésima geração; e, $\bar{x}$ é a média geral da covariável no experimento.

De cada um dos experimentos foi obtida a média dos trifólios avaliados e análises de variância foram realizadas utilizando somente os dados das famílias $F_{3: 2} \mathrm{e}$ $\mathrm{F}_{4: 2}$, individualmente; foram analisados os dados da avaliação de cada trifólio e a média dos trifólios. O modelo da análise foi determinado por:

$$
\mathrm{Y}_{\mathrm{ij}}=\mu+\mathrm{t}_{\mathrm{i}}+\mathrm{e}_{\mathrm{ij}} \text {, }
$$

sendo $\mathrm{Y}_{\mathrm{ij}}$ a média do i-ésimo tratamento; $\mu$ é a média geral do experimento; e, $\mathrm{e}_{\mathrm{ij}}$ é o erro experimental.

A herdabilidade no sentido amplo, com base nas famílias $F_{3: 2}$ e $F_{4: 2}$, foi calculada a partir dos componentes da variação, utilizando-se a fórmula:

$$
h^{2}=\sigma_{g}^{2} /\left(\sigma_{g}^{2}+\sigma^{2} / n\right),
$$

sendo $h^{2}$ a herdabilidade no sentido amplo, $\sigma_{\mathrm{g}}^{2}$ é a variância genética, $\sigma^{2}$ é a variância ambiental e $\mathrm{n}$ à média harmônica do número de indivíduos que compõem as famílias de cada geração.

\subsubsection{Extração de DNA e genotipagem com marcadores microssatélites}

\subsubsection{Extração de DNA}

Foram coletadas folhas recém expandidas de 116 plantas $F_{2}$ derivadas do cruzamento FT-2 x Davis. Imediatamente após a coleta, as folhas foram congeladas em nitrogênio líquido e armazenadas em ultrafreezer a $-80^{\circ} \mathrm{C}$ (oitenta graus negativos). $\mathrm{O}$ processo de extração de DNA foi realizado com base no protocolo descrito por Keim et al. (1988), com algumas modificações. Aproximadamente um grama de tecido foliar 
congelado foi pulverizado utilizando-se almofariz, procedendo-se a transferência de uma pequena parte da amostra para microtubos com capacidade para 1,5 $\mathrm{mL}$ e adição de tampão de extração na proporção de quatro vezes o volume da amostra [100 mM tris, $\mathrm{pH}$ 8,0, 1,4 M NaCl, $20 \mathrm{mM}$ EDTA, $1 \%(\mathrm{~m} / \mathrm{v})$ brometo de trimetil $\mathrm{N}$-cetil amônio (CTAB), $0,1 \%(\mathrm{v} / \mathrm{v}) 2$-mercaptoetanol]. A suspensão foi incubada a $65^{\circ} \mathrm{C}$ por 60 minutos, com agitação a cada 15 minutos. Após a incubação, as amostras foram centrifugadas a 6000 rpm por 10 minutos, com transferência da fase aquosa para outro microtubo. Adicionouse igual volume de clorofórmio-álcool isoamílico (24:1), procedendo-se a mistura por inversões e centrifugação a $6000 \mathrm{rpm}$ por 15 minutos. Estes últimos passos foram repetidos. O DNA foi precipitado com a adição de isopropanol (2/3 do volume) e, posteriormente, a solução foi centrifugada a $14000 \mathrm{rpm}$ por 10 minutos, descartando-se o sobrenadante e adicionando-se $0,5 \mathrm{~mL}$ de etanol $70 \%$. Realizou-se uma nova centrifugação e descarte do sobrenadante, para diluição do DNA precipitado em 0,4 mL de $10 \mathrm{mM}$ tris/1 mM EDTA, $\mathrm{pH}$ 8,0. Para finalizar, foi adicionada a enzima RNAse A na proporção de $40 \mu \mathrm{g} / \mathrm{mL}$, com incubação a $37^{\circ} \mathrm{C}$ por pelo menos 30 minutos.

Após a extração do DNA das folhas de soja, foi realizada sua quantificação, determinada por análise espectrofotométrica, por leitura de absorbância a $260 \mathrm{~nm}$ e 280 $\mathrm{nm}$, considerando que cada unidade de leitura a $260 \mathrm{~nm}$ corresponde à concentração de $50 \mu \mathrm{g} / \mathrm{mL}$ de DNA de fita dupla (Sambrook et al., 1989). Após determinada a concentração de DNA, as amostras foram diluídas utilizando água milliQ para uma concentração final de $10 \mathrm{ng} / \mu \mathrm{L}$.

\subsubsection{Amplificações de Microssatélites}

Foram testados vários marcadores moleculares de microssatélites, de forma a contemplar da melhor forma todo o genoma das cultivares de soja utilizadas neste estudo, baseando-se no mapa genético integrado da soja (Cregan et al., 1999). Os pares de primers que serão utilizados, pertencem à coleção de primers da Embrapa Soja. 
As amplificações foram realizadas no termociclador Perkin-Elmer Gene Amp 9600 (Perkin-Elmer Corp., Norwalk, CT), de acordo com o protocolo descrito por Akkaya et al., 1992). Em todas os processos de amplificação, foram incluídos dois controles negativos (amostras sem DNA) para assegurar a qualidade dos resultados.

\subsubsection{Análise genética dos dados fenotípicos e mapeamento}

Após identificados os marcadores polimórficos entre os genótipos parentais e utilização destes para a genotipagem dos indivíduos da população de plantas $F_{2}$, foi aplicado o teste de conformidade do modelo $(\chi 2)$ para cada um dos marcadores, para verificar a adequação ao modelo de distribuição genotípica de 1:2:1.

As análises de regressão e as análises de variância foram realizadas utilizandose o pacote estatístico SAS (SAS, 1999). A ordenação mais provável do mapa genético e as distâncias de ligação entre os marcadores foram determinadas por análises de ligação multi-ponto (mult-point linkage analysis) utilizando o programa Mapmaker/Exp a um $\mathrm{LOD}=3,0$ com distância máxima de Kosambi de 37,2 cM (Lander et al., 1987).

Cada combinação entre a característica quantitativa e os loci SSR foi submetida à análise de regressão simples para identificar a ligação entre o marcador e o caráter. Esta análise estima a variância fenotípica do caráter explicada por efeitos aditivos. Análises de regressão múltiplas foram realizadas com os marcadores associados aos QTLs identificados nas análises de regressão simples. Essas análises somente foram realizadas para os trifólios (NI\#TF) e para a média dos trifólios (NIMTF) onde foram identificados pelo menos dois marcadores significativos, e que apresentaram efeitos na redução do caráter, ou seja, no nível de infecção a S. glycines.

As análises de variância foram realizadas utilizando o modelo linear proposto por Edwards et al. (1987). De acordo com Lynch \& Walsh (1998) esta é uma estratégia para detectar QTLs, onde as médias do caráter associadas aos diferentes genótipos do marcador são testadas para identificação de diferenças significativas. No caso dos marcadores SSR, três genótipos são identificados (marcador codominante): $A_{1} A_{1}, A_{1} A_{2}$ 
e $\mathrm{A}_{2} \mathrm{~A}_{2}$. Essa análise estima a variância fenotípica do caráter, explicada por efeitos aditivos e não aditivos de QTLs detectados, além de indicar os desvios do loco marcador dos efeitos lineares e para avaliar os efeitos de dominância (Dudley, 1993). A proporção da variância fenotípica explicada por cada QTL detectado foi estimada pelo coeficiente de determinação (R2) (Edwards et al., 1987). Nessas análises, os dois graus de liberdade referentes às três classes de cada marcador foram divididos em um grau de liberdade para efeitos de dominância e um grau de liberdade para efeitos aditivos (estimados nas análises de regressão simples).

Os QTLs também foram analisados por interval mapping ou mapeamento por intervalo utilizando-se o programa Mapmaker/QTL (Paterson et al., 1988). Um LOD score de 2,0 foi aceito como o limiar para identificar a localização de QTLs. Geralmente, o LOD score mínimo adotado para localizar um QTL com segurança é 3,0; todavia, devido ao controle genético complexo do caráter (Brogin, 2001; Brogin et al., 2003b) e por se tratar de estudos iniciais utilizando marcadores moleculares para identificação de QTLs envolvidos na resistência à mancha parda, um LOD inferior foi adotado. A posição do pico de LOD em cada intervalo significativo sugere a localização de um QTL (Lander and Botstein, 1989; Lincoln et al., 1993, Paterson et al. 1988).

\subsection{Resultados e Discussão}

\subsubsection{Avaliação das progênies $F_{3: 2}$ e $F_{4: 2}$ para resistência a $S$. glycines}

As progênies $F_{3: 2}$ e $F_{4: 2}$ foram avaliadas em casa-de-vegetação, juntamente com os genótipos parentais e em experimentos distintos, após inoculação artificial com o patógeno, de acordo com uma escala de notas para nível de infecção variando de zero a dez. A metodologia de avaliação, adequada em trabalhos anteriores que estudaram o controle genético para o caráter (Brogin, 2001; Brogin, 2003b), mostrou-se adequada aos objetivos desse trabalho pois como as parcelas eram constituídas de apenas uma planta, várias famílias puderam ser avaliadas em um mesmo local e em um mesmo 
experimento, reduzindo o efeito do ambiente sobre o caráter e aumentando a precisão dos dados experimentais. As dificuldades para obtenção de dados a campo são grandes, pois além do caráter apresentar herança quantitativa, outras doenças ocorrem simultaneamente à mancha parda, reduzindo a precisão nas avaliações dos sintomas característicos da doença. A utilização de um genótipo homogêneo em todos os vasos dos experimentos, característica importante nessa metodologia, foi de grande utilidade para o monitoramento da doença em toda a extensão dos experimentos, além de comprovar a eficiência da inoculação. Uma síntese dos dados obtidos nas avaliações dos dois experimentos pode ser observada nas Tabelas 1 e 2 . Como era esperado, as médias do nível de infecção em todos os trifólios da cultivar FT-2 foi sempre menor do que as da cultivar Davis. A variância dentro das famílias também foi sempre menor do que a variância entre as famílias.

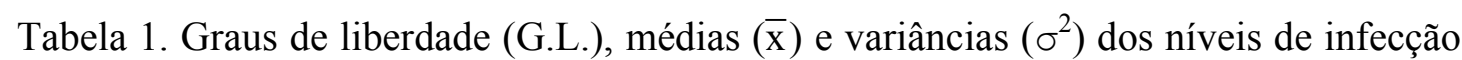
no primeiro (NI1TF), segundo (NI2TF) e terceiro trifólios (NI3TF) e nível de infecção médio dos trifólios (NIMTF), avaliados nas plantas das gerações parentais e $\mathrm{F}_{3: 2}$ do cruzamento entre FT-2 x Davis (dados originais)

\begin{tabular}{lccccccccccccc}
\hline \multirow{2}{*}{ Geração } & \multicolumn{3}{c}{ NI1TF } & \multicolumn{4}{c}{ NI2TF } & \multicolumn{4}{c}{ NI3TF } & \multicolumn{3}{c}{ NIMTF } \\
& G.L. & $\overline{\mathrm{x}}$ & $\sigma^{2}$ & G.L. & $\overline{\mathrm{x}}$ & $\sigma^{2}$ & G.L. & $\overline{\mathrm{x}}$ & $\sigma^{2}$ & G.L. & $\overline{\mathrm{x}}$ & $\sigma^{2}$ \\
\hline Parental & & & & & & & & & & & & \\
FT-2 & 19 & 4,2 & 6,8 & 19 & 4,15 & 6,98 & 19 & 2,05 & 1,1 & 19 & 3,47 & 3,28 \\
Davis & 17 & 7,67 & 6,35 & 17 & 7,78 & 8,07 & 17 & 6,67 & 8,35 & 18 & 6,79 & 8,55 \\
F $3: 2$ & & & & & & & & & & & & \\
Entre & 115 & 6,45 & 14,71 & 115 & 6,24 & 15,25 & 115 & 3,85 & 7,49 & 115 & 5,20 & 9,52 \\
Dentro & 456 & & 8,56 & 456 & & 7,45 & 571 & & 6,39 & 456 & & 4,73 \\
Total & 571 & & 9,81 & 571 & & 9,04 & 571 & & 6,61 & 571 & & 5,71 \\
\hline
\end{tabular}


Tabela 2. Graus de liberdade (G.L.), médias $(\overline{\mathrm{x}})$ e variâncias $\left(\sigma^{2}\right)$ dos níveis de infecção no primeiro (NI1TF), segundo (NI2TF), terceiro (NI3TF) e quarto trifólios (NI4TF) e nível de infecção médio dos trifólios (NI1TF), avaliados nas plantas das gerações parentais e $\mathrm{F}_{4: 2}$ do cruzamento FT-2 x Davis (dados originais)

\begin{tabular}{lccccccccccccccccc}
\hline \multirow{2}{*}{ Geração } & \multicolumn{3}{c}{ NI1TF } & \multicolumn{1}{c}{ NI2TF } & \multicolumn{1}{c}{ NI3TF } & \multicolumn{4}{c}{ NI4TF } & \multicolumn{4}{c}{ NIMTF } \\
& G.L. & $\overline{\mathrm{x}}$ & $\sigma^{2}$ & G.L. & $\overline{\mathrm{x}}$ & $\sigma^{2}$ & G.L. & $\overline{\mathrm{x}}$ & $\sigma^{2}$ & G.L. & $\overline{\mathrm{x}}$ & $\sigma^{2}$ & G.L. & $\overline{\mathrm{x}}$ & $\sigma^{2}$ \\
\hline Parental & & & & & & & & & & & & & & & & & \\
FT-2 & 11 & 2,00 & 1,64 & 11 & 2,83 & 1,97 & 11 & 2,50 & 0,82 & 11 & 1,92 & 0,63 & 11 & 2,31 & 0,58 \\
Davis & 10 & 2,55 & 2,87 & 10 & 4,27 & 11,0 & 10 & 5,18 & 3,96 & 10 & 5,00 & 7,80 & 10 & 4,25 & 4,63 \\
$F_{4: 2}$ & & & & & & & & & & & & & & & \\
Entre & 115 & 3,46 & 7,61 & 115 & 3,80 & 7,89 & 115 & 4,50 & 6,72 & 115 & 3,75 & 5,53 & 115 & 3,88 & 5,03 \\
Dentro & 563 & & 5,15 & 563 & & 4,43 & 563 & & 3,94 & 563 & & 3,76 & 563 & & 2,83 \\
Total & 678 & & 5,57 & 678 & & 5,02 & 678 & & 4,42 & 678 & & 4,06 & 678 & & 3,21 \\
\hline
\end{tabular}

Os dados obtidos nas avaliações do genótipo padrão de suscetibilidade (cv. Davis), presente em todos os vasos dos experimentos, foram utilizados para análises de covariância, juntamente com os dados das avaliações dos genótipos parentais e das gerações segregantes. Verificou-se a significância da covariável no modelo estatístico (dados não apresentados), procedendo-se à correção dos dados para essa covariável, utilizando coeficientes de regressão linear ( $\beta$ s) obtidos para cada geração, na análise de cada experimento.

O efeito da correção dos dados para a covariável pode ser observado quando são comparados os resultados das análises de variância dos dados das avaliações dos genótipos parentais, utilizando dados não corrigidos e corrigidos para a covariável, apresentados nas Tabelas 3 e 4: observou-se que há uma tendência à redução dos quadrados médios dos resíduos e, conseqüentemente, dos coeficientes de variação dos experimentos, sem alteração significativa das médias dos tratamentos; adicionalmente, a redução do quadrado médio do resíduo aumentou a sensibilidade da análise fazendo, por exemplo, com que o efeito da interação entre genótipos parentais e trifólios avaliados se tornasse significativo após a correção dos dados no experimento no qual as progênies $\mathrm{F}_{4: 2}$ foram avaliadas (Tabela 4), justificando a utilização da covariável para melhorar a 
qualidade dos dados. Portanto, todas as análises estatístico-genéticas posteriores, a partir dessa etapa do trabalho, foram realizadas com dados corrigidos para a covariável.

Tabela 3. Resumo das análises de variância do nível de infecção por S. glycines avaliado nos genótipos parentais FT-2 e Davis do experimento no qual as progênies $\mathrm{F}_{3: 2}$ foram avaliadas, utilizando dados originais (não corrigidos) e dados corrigidos para a covariável

\begin{tabular}{|c|c|c|c|}
\hline \multirow{2}{*}{ Fontes de Variação } & \multirow{2}{*}{ G.L. } & \multicolumn{2}{|c|}{ Quadrados Médios } \\
\hline & & Dados não corrigidos & Dados corrigidos \\
\hline Tratamentos & 5 & $101,36^{* *}$ & $105,67 * *$ \\
\hline Gen. parentais & 1 & $433,11 * *$ & $460,08 * *$ \\
\hline Trifólios & 2 & $33,18 * *$ & $30,97 * *$ \\
\hline Par. x Trif. & 2 & 3,67 & 3,17 \\
\hline Resíduo & 108 & 6,20 & 5,94 \\
\hline Média Trat. & & 5,32 & 5,24 \\
\hline CV $(\%)$ & & 46,85 & 46,50 \\
\hline$h^{2} \mathrm{a}$ & & 0,94 & 0,94 \\
\hline
\end{tabular}

** significativo a $\mathrm{P}<0,01$

$\mathrm{h}^{2} \mathrm{a}$ : herdabilidade no sentido amplo

Tabela 4. Resumo das análises de variância do nível de infecção por S. glycines avaliado nos genótipos parentais FT-2 e Davis do experimento no qual as progênies $\mathrm{F}_{4: 2}$ foram avaliadas, utilizando dados originais (não corrigidos) e dados corrigidos para a covariável

\begin{tabular}{lccc}
\hline \multirow{2}{*}{ Fontes de Variação } & \multirow{2}{*}{ G.L. } & \multicolumn{2}{c}{ Quadrado Médio } \\
& & $20,09^{* *}$ & $18,94^{* *}$ \\
\hline Tratamentos & 7 & $86,18^{* *}$ & $77,34^{* *}$ \\
$\quad$ Gen. parentais & 1 & $10,39^{*}$ & $9,11^{* *}$ \\
$\quad$ Trifólios & 3 & 7,75 & $9,29 * *$ \\
$\quad$ Par. x Trif. & 3 & 3,72 & 2,14 \\
Resíduo & 84 & 3,24 & 3,20 \\
Média Trat. & & 59,51 & 45,72 \\
CV (\%) & & 0,81 & 0,89 \\
$\mathrm{~h}^{2} \mathrm{a}$ & & & \\
\hline
\end{tabular}

* significativo a $\mathrm{P}<0,05$

** significativo a $\mathrm{P}<0,01$

$\mathrm{h}^{2} \mathrm{a}$ : herdabilidade no sentido amplo 
Observando-se ainda os resultados das Tabelas 3 e 4, houve diferenças significativas $(\mathrm{P}<0,01)$ entre os tratamentos nos dois experimentos. No desdobramento das análises, diferenças significativas foram observadas entre os genótipos parentais e entre os trifólios avaliados. As diferenças entre os genótipos parentais já eram esperadas, visto que estes divergem para o caráter. A diferença entre os trifólios avaliados indica que a reação ao patógeno é diferenciada em cada um deles, pois no momento da inoculação os trifólios possuiam idades diferentes e, provavelmente, a expressão dos genes envolvidos na resistência foi diferenciada. A observação desse tipo de reação ao patógeno é importante nesse patossistema, pois se trata de um caráter quantitativo e qualquer diferença entre os genótipos é fundamental para a análise de seu comportamento.

Após a correção dos dados, foram obtidas novamente as médias e variâncias das gerações avaliadas nos experimentos (Tabelas 5 e 6). Comparando-se os resultados apresentados nas Tabelas 3 e 4 (dados não corrigidos para a covariável) com os resultados das Tabelas 5 e 6 (dados corrigidos), pode-se observar que as médias do caráter nas gerações variaram pouco após a correção. Houve uma tendência de redução da variância das gerações parentais na variância dentro de famílias, contribuindo para maior diferenciação entre as famílias, ou seja, aumento da variância entre famílias.

Tabela 5. Graus de liberdade (G.L.), médias $(\overline{\mathrm{x}})$ e variâncias $\left(\sigma^{2}\right)$ dos níveis de infecção no primeiro (NI1TF), segundo (NI2TF) e terceiro trifólios (NI3TF) e nível de infecção médio dos trifólios (NIMTF), avaliados nas plantas das gerações parentais e $\mathrm{F}_{3: 2}$ do cruzamento FT-2 x Davis (dados corrigidos para a covariável)

\begin{tabular}{|c|c|c|c|c|c|c|c|c|c|c|c|c|}
\hline \multirow{2}{*}{$\begin{array}{l}\text { Geraçã } \\
\text { o }\end{array}$} & \multicolumn{3}{|c|}{ NI1TF } & \multicolumn{3}{|c|}{ NI2TF } & \multicolumn{3}{|c|}{ NI3TF } & \multicolumn{3}{|c|}{ NIMTF } \\
\hline & G.L. & $\overline{\mathrm{x}}$ & $\sigma^{2}$ & G.L. & $\overline{\mathrm{x}}$ & $\sigma^{2}$ & G.L. & $\overline{\mathrm{x}}$ & $\sigma^{2}$ & G.L. & $\overline{\mathrm{x}}$ & $\sigma^{2}$ \\
\hline \multicolumn{13}{|l|}{ Parental } \\
\hline FT-2 & 19 & 4,19 & 6,80 & 19 & 3,80 & 6,02 & 19 & 2,01 & 1,02 & 19 & 3,33 & 2,95 \\
\hline Davis & 17 & 7,67 & 5,96 & 17 & 7,76 & 7,97 & 17 & 6,64 & 8,33 & 17 & 7,36 & 3,97 \\
\hline \multicolumn{13}{|l|}{$F_{3: 2}$} \\
\hline Entre & 115 & 6,17 & 30,50 & 115 & 6,02 & 28,90 & 115 & 3,58 & 26,20 & 115 & 5,25 & 11,20 \\
\hline Dentro & 456 & & 5,85 & 456 & & 5,39 & 571 & & 4,95 & 456 & & 2,34 \\
\hline Total & 571 & & 10,90 & 571 & & 10,20 & 571 & & 9,28 & 571 & & 4,15 \\
\hline
\end{tabular}


Tabela 6. Graus de liberdade (G.L.), médias $(\overline{\mathrm{x}})$ e variâncias $\left(\sigma^{2}\right)$ dos níveis de infecção no primeiro (NI1TF), segundo (NI2TF), terceiro (NI3TF) e quarto (NI4TF) trifólios e nível de infecção médio dos trifólios (NIMTF) das plantas das gerações parentais e $\mathrm{F}_{4: 2}$ do cruzamento FT- 2 x Davis (dados corrigidos para a covariável)

\begin{tabular}{lccccccccccccccccc}
\hline \multirow{2}{*}{ Geração } & \multicolumn{3}{c}{ NI1TF } & \multicolumn{4}{c}{ NI2TF } & \multicolumn{4}{c}{ NI3TF } & \multicolumn{4}{c}{ NI4TF } & \multicolumn{3}{c}{ NIMTF } \\
& G.L. & $\overline{\mathrm{x}}$ & $\sigma^{2}$ & G.L. & $\overline{\mathrm{x}}$ & $\sigma^{2}$ & G.L. & $\overline{\mathrm{x}}$ & $\sigma^{2}$ & G.L. & $\overline{\mathrm{x}}$ & $\sigma^{2}$ & G.L. & $\overline{\mathrm{x}}$ & $\sigma^{2}$ \\
\hline Parental & & & & & & & & & & & & & & & & & \\
FT-2 & 11 & 1,99 & 1,43 & 11 & 2,85 & 1,95 & 11 & 2,55 & 0,78 & 11 & 1,92 & 0,48 & 11 & 2,33 & 0,49 \\
Davis & 10 & 2,60 & 1,82 & 10 & 3,85 & 4,12 & 10 & 4,88 & 2,46 & 10 & 5,31 & 4,53 & 10 & 4,16 & 1,87 \\
F $_{4: 2}$ & & & & & & & & & & & & & & & \\
Entre & 115 & 3,56 & 6,84 & 115 & 3,86 & 7,59 & 115 & 4,43 & 6,06 & 115 & 3,76 & 6,38 & 115 & 3,90 & 4,22 \\
Dentro & 563 & & 3,69 & 563 & & 2,84 & 563 & & 2,42 & 563 & & 2,41 & 563 & & 1,42 \\
Total & 678 & & 4,23 & 678 & & 3,66 & 678 & & 3,05 & 678 & & 3,09 & 678 & & 1,90 \\
\hline
\end{tabular}

As análises de variância dos níveis de infecção nas famílias $\mathrm{F}_{3: 2}$ e $\mathrm{F}_{4: 2}$ revelaram diferenças significativas entre os tratamentos (progênies) nos dois experimentos (Tabelas 7 e 8). No experimento no qual as famílias $F_{3: 2}$ foram avaliadas, os coeficientes de variação (CV) variaram de $28,42 \%$ a $62,44 \%$ (Tabela 7); os CVs variaram de $30,51 \%$ a 53,91\% (Tabela 8) no experimento no qual as famílias $\mathrm{F}_{4: 2}$ foram avaliadas.

Os valores de herdabilidade no sentido amplo $\left(\mathrm{h}^{2}{ }_{\mathrm{a}}\right)$ calculados para o caráter foram maiores no experimento no qual as famílias $F_{3: 2}$ foram avaliadas quando comparados aos valores obtidos no experimento no qual as famílias $\mathrm{F}_{4: 2}$ foram avaliadas; esses valores variaram de 0,47 a 0,78 . Os valores de herdabilidade tendem a ser maiores nas análises com médias dos trifólios pois, quando as médias são calculadas, os erros experimentais são diluídos e o quadrado médio do resíduo é reduzido. Esse fato pode ser observado nas estimativas dos erros experimentais obtidos quando as análises de variância foram realizadas utilizando os dados das médias dos trifólios dos dois experimentos (Tabelas 7 e 8). Além disso, o cálculo da média dos trifólios representa a reação da planta à mancha parda de uma maneira geral, sendo recomendada para uma caracterização eficiente da planta para fins de avaliação e seleção (Brogin, 2001; Brogin, 2003b). 
Tabela 7. Resumo da análise de variância dos níveis de infecção por S. glycines avaliados nas famílias $\mathrm{F}_{3: 2}$, utilizando dados corrigidos para a covariável

\begin{tabular}{lccccc}
\hline \multicolumn{1}{c}{$\begin{array}{c}\text { Fontes de } \\
\text { Variação }\end{array}$} & \multirow{2}{*}{ G.L. } & $1^{\text {o }}$ Trifólio & $2^{\text {o }}$ Trifólio & $3^{\text {o }}$ Trifólio & Média Trif. \\
\hline Tratamentos & 115 & $30,78^{* *}$ & $28,68^{* *}$ & $23,14^{* *}$ & $11,27^{* *}$ \\
Resíduo & 456 & 5,87 & 5,43 & 5,00 & 2,24 \\
Média Trat. & & 6,18 & 6,02 & 3,58 & 5,26 \\
CV (\%) & 39,24 & 38,68 & 62,44 & 28,42 \\
$\mathrm{~h}^{2} \mathrm{a}$ & 0,81 & 0,81 & 0,78 & 0,80 \\
\hline$* *$ significativo a P $<0,01$ & & &
\end{tabular}

Tabela 8. Resumo da análise de variância dos níveis de infecção por S. glycines avaliados nas famílias $\mathrm{F}_{4: 2}$, utilizando dados corrigidos para a covariável

\begin{tabular}{lcccccc}
\hline \multicolumn{1}{c}{$\begin{array}{c}\text { Fontes de } \\
\text { Variação }\end{array}$} & \multirow{2}{*}{ G.L. } & \multicolumn{5}{c}{ Quadrado Médio / Famílias $\mathrm{F}_{4: 2}$} \\
& & $1^{\mathrm{o}}$ Trifólio & $2^{\mathrm{o}}$ Trifólio & $3^{\mathrm{o}}$ Trifólio & $4^{\mathrm{o}}$ Trifólio & Média Trif. \\
\hline Tratamentos & 115 & $6,87^{* *}$ & $7,61^{* *}$ & $6,07^{* *}$ & $6,50^{* *}$ & $4,31^{* *}$ \\
Resíduo & 563 & 3,67 & 2,81 & 2,42 & 2,43 & 1,42 \\
Média Trat. & & 3,56 & 3,86 & 4,43 & 3,77 & 3,90 \\
CV (\%) & 53,91 & 43,39 & 35,08 & 41,41 & 30,51 \\
$\mathrm{~h}^{2} \mathrm{a}$ & 0,47 & 0,63 & 0,60 & 0,63 & 0,67 \\
\hline$* *$ significativo a $\mathrm{P}<0,01$ \\
$\mathrm{~h}^{2}$ a: herdabilidade no sentido amplo
\end{tabular}

\subsubsection{Construção do mapa genético de ligação}

Para a identificação de polimorfismo genético entre os parentais FT-2 e Davis foram testados 260 marcadores moleculares microssatélites distribuídos nos 20 grupos de ligação da soja descritos por Cregan et al. (1999), sendo que 41 marcadores identificaram polimorfismo entre os parentais e foram utilizados para a genotipagem da população de mapeamento $F_{2}$. Estes marcadores foram selecionados porque, além de identificarem polimorfismo entre os genótipos parentais, apresentaram melhor separação das bandas nos géis de eletroforese e alta resolução na identificação do genótipo heterozigótico. O baixo polimorfismo identificado entre os genomas dos genótipos 
paentais pode ser explicado em parte pela constituição genética de cada um deles, descritas na Tabela 9: observa-se que há vários ancestrais comuns nas genealogias dos genótipos parentais, o que contribui para uma distância genética menor entre eles. Conseqüentemente, estes genótipos parentais são muito similares fenotipicamente, como por exemplo na cor de flor, cor de pubescência, ciclo, altura da planta, dentre outras características. No entanto, os genótipos parentais são divergentes para o caráter resistência à mancha parda (Brogin, 2001).

Embora a cobertura do genoma fornecida pelos 41 marcadores SSR seja baixa, os dados obtidos neste trabalho estabelecem o estágio inicial de estudos adicionais dos QTLs envolvidos na resistência à mancha parda em soja. Destes 41 marcadores utilizados, apenas um (Satt175) apresentou desvio da proporção esperada de indivíduos (1:2:1) e não foi utilizado nas análises e na construção do mapa genético. Dos 40 marcadores restantes, somente 24 foram mapeados na população de plantas $F_{2}$, com uma distância máxima de Kosambi de 37,2 cM. Oito grupos de ligação foram detectados como representativos daqueles descritos por Cregan et al. (1999) e Song et al. (2004) (Figura 1). A cobertura total do mapa foi de 304,9 cM e a ordem e a distância dos marcadores no mapa são comparáveis aos mapas integrados de ligação descritos pelos mesmos autores, exceto para o grupo de ligação (LG) C2 onde onde houve inversão na ordem de parte dos marcadores.

Tabela 9. Constituição genética das cultivares de soja Davis e FT-2, , utilizadas como genitores

\begin{tabular}{ccc}
\hline Cultivar & Constituição Genética \\
Davis & $1 / 8 \mathrm{~A}+1 / 4 \mathrm{~B}+3 / 16 \mathrm{C}+3 / 16 \mathrm{E}+1 / 4 \mathrm{~F}$ \\
FT-2 & $1 / 8 \mathrm{~A}+1 / 4 \mathrm{~B}+1 / 8 \mathrm{C}+1 / 8 \mathrm{D}+1 / 8 \mathrm{E}+1 / 8 \mathrm{G}+1 / 8 \mathrm{H}$ \\
Letra Símbolo & Identificação & Origem \\
\hline $\mathrm{A}$ & CNS (provavelmente PI 71597) & Sul da China \\
$\mathrm{B}$ & Roanoke (Nanking) & Nanking, China \\
$\mathrm{C}$ & Tokyo (PI 8424) & Yokohama, Japão \\
$\mathrm{D}$ & S-100 (Illini ou A.K.3) & Nordeste da China \\
$\mathrm{E}$ & PI 54610 & Nordeste da China \\
$\mathrm{F}$ & PI 37335 (Arksoy) & Pingyang, Coréia \\
$\mathrm{G}$ & PI 36846 (Dunfield) & Nordeste da China \\
$\mathrm{H}$ & PI 6396 (Haberlandt) & Pingyang, Coréia \\
\hline
\end{tabular}




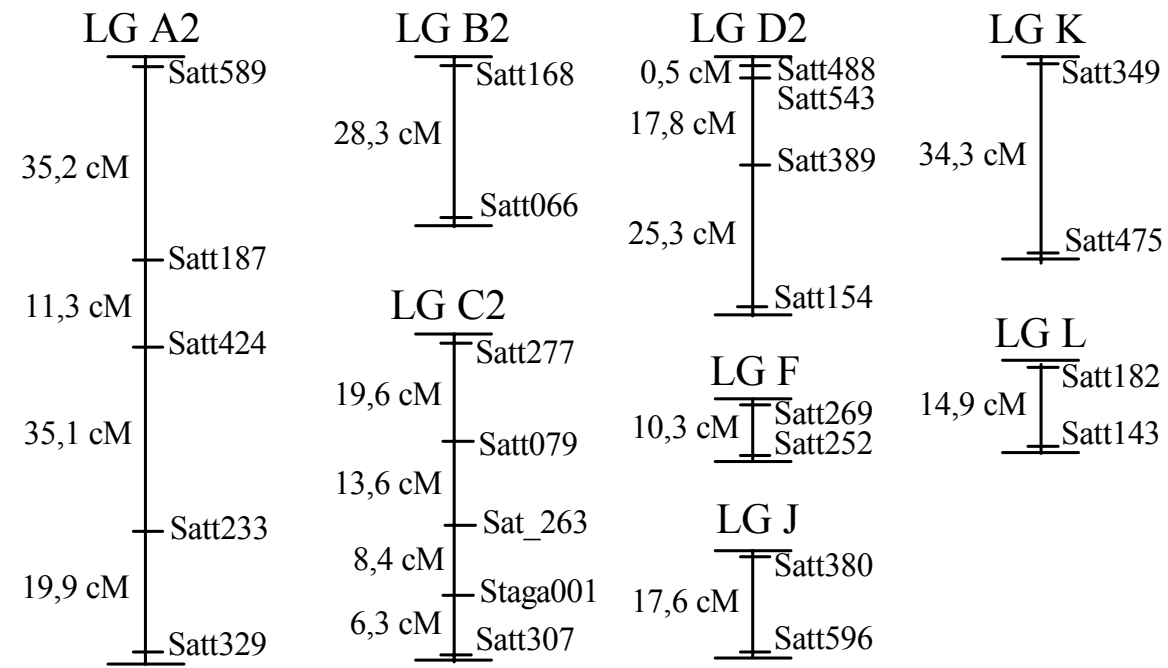

Figura 1 - Mapa de ligação parcial da soja baseado em informações genotípicas de 24 marcadores SSR de uma população de mapeamento $F_{2}$ originada do cruzamento entre as cultivares de soja FT-2 e Davis. Os locos marcadores são mostrados à direita de cada grupo de ligação (LG) e as distâncias genéticas estão indicadas à esquerda, conforme determinado pelo programa Mapmaker/Exp 3.0 e distância de Kosambi de 37,2 cM.

\subsubsection{Marcadores SSR associados à resistência a S. glycines}

Os resultados das análises de regressão com os locos marcadores como as variáveis independentes e o nível de infecção de mancha parda nos diferentes trifólios avaliados e a média dos trifólios como as variáveis independentes, utilizando dados das avaliações das gerações $F_{3: 2}$ e $F_{4: 2}$, revelaram nove associações significativas $(P \leq 0,05$, Tabela 10) entre loco marcador e QTL devido aos efeitos aditivos identificados para o caráter na geração $F_{3: 2}$ e 12 associações significativas quando os dados da geração $F_{4: 2}$ foram analisados. O número de associações contabilizadas em cada caso considera a identificação de determinados marcadores associados a QTLs em mais de um trifólio. 


\subsubsection{Análises dos dados das progênies $F_{3: 2}$}

Considerando a distância de Kosambi de 37,2 cM, os marcadores identificados em associação com QTLs, nas análises de regressão, envolvidos na resistência à mancha parda avaliada nas progênies $\mathrm{F}_{3: 2}$, foram mapeados em dois grupos distintos de ligação (LG) (Tabela 10): LG B2 (Satt168) e LG D2 (Satt154 e Satt389). Não foi possível incorporar o marcador Satt577 ao grupo de ligação B2, nem o marcador Satt460 ao grupo de ligação C2 conforme o esperado, de acordo com os mapas integrados de ligação de Cregan et al., (1999) e Song et al., (2004). Outro marcador (Satt396) apresentou associação significativa a um QTL, mas não foi possível incorporá-lo ao mapa genético de ligação. O nível de infecção no primeiro trifólio (NI1TF) foi significativamente associado aos locos marcadores Satt168, Satt460, Satt154 e Satt389, enquanto que o nível de infecção no segundo trifólio (NI2TF) foi associado ao marcador Satt577, não integrado ao mapa de ligação. O marcador Satt396, também não integrante do mapa de ligação obtido, foi associado ao nível de infecção no terceiro trifólio (NI3TF) e ao nível de infecção médio dos trifólios (NIMTF). Além de estar associado ao NI1TF, o marcador Satt154 também se associou significativamente ao nível de infecção no terceiro trifólio (NI3TF). A variação fenotípica $\left(\mathrm{R}^{2}\right)$ explicada por cada marcador associado a QTL variou de 3,3\% a 6,3\% (Tabela 10), sendo que os maiores valores de $\mathrm{R}^{2}$ foram resultado da associação do marcador Satt168 aos QTLs envolvidos na determinação do NI1TF e NIMTF. Este marcador está associado a um alelo do QTL no genótipo parental resistente que condiciona o aumento do nível de infecção, ou seja, Satt168 está mapeando um alelo de suscetibilidade no genitor resistente, sugerindo que a resistência à mancha parda é incompleta e pode ser melhorada. Os demais marcadores estão relacionados ao caráter no sentido de reduzir o nível de infecção. Os baixos valores dos coeficiente de determinação $\left(\mathrm{R}^{2}\right)$ destes QTLs condizem com a natureza quantitativa da resistência da soja à mancha parda (Brogin, 2003). No entanto, os valores de herdabilidade dos QTLs identificados é considerado alto para o caráter (Tabela 11). Por se tratar do primeiro trabalho utilizando marcadores moleculares para o mapeamento de QTLs envolvidos na resistência à essa doença, ainda não se tem uma referência sobre a 
magnitude dos efeitos dos QTLs e nem se há regiões do genoma mais relacionadas ao caráter.

Uma análise de regressão múltipla foi realizada para os marcadores associados a NI1TF que apresentaram efeitos na redução do nível de infecção (Satt154, Satt389 e Satt460) (Tabela 10). O modelo resultante foi significativo $(\mathrm{P}=0,002)$, sendo a variação fenotípica $\left(\mathrm{R}^{2}\right)$ explicada pelos marcadores conjuntamente de $16,2 \%$.

As análises de variância realizadas para marcadores associados a QTLs, identificados pela análise de regressão, geralmente não revelaram diferenças significativas entre as médias das classes dos marcadores $\left(\mathrm{A}_{1} \mathrm{~A}_{1}, \mathrm{~A}_{1} \mathrm{~A}_{2}\right.$ e $\left.\mathrm{A}_{2} \mathrm{~A}_{2}\right)$ (Tabela 10). Somente as médias das classes genotípicas do marcador Satt168 para NI1TF e NIMTF foram significativamente diferentes pelo teste de comparação de médias (Tukey; $\mathrm{P} \leq 0,05)$. Para este marcador, os efeitos genéticos aditivos predominaram e foram altamente significativos. A herdabilidade nos dois casos foi de 0,73 (Tabela 11).

O marcador Satt172, identificado na análise de variância associado ao NI3TF, apresentou apenas efeito de dominância e está associado a um QTL no genótipo parental resistente que contribui para o aumento do nível de infecção. Efeitos de dominância têm sido identificados em muitos estudos de mapeamento de QTLs (Lynch \& Walsh, 1998). 
Tabela 10. Distribuição de ligação dos marcadores que apresentaram associação a diferenças fenotípicas para o nível de infecção de mancha parda no primeiro (NI1TF), segundo (NI2TF) e terceiro trifólios (NI3TF) e nível de infecção médio dos trifólios (NIMTF), avaliados em plantas da geração $\mathrm{F}_{3: 2}$ originadas do cruzamento entre as cultivares de soja FT-2 $\left(\mathrm{A}_{1} \mathrm{~A}_{1}\right)$ e Davis $\left(\mathrm{A}_{2} \mathrm{~A}_{2}\right)$, determinadas por análise de regressão simples

\begin{tabular}{ccccccc}
\hline $\begin{array}{c}\text { Grupos de } \\
\text { Ligação }\end{array}$ & $\begin{array}{c}\text { Marcador } \\
\text { SSR }\end{array}$ & $\begin{array}{c}\text { Nível de Significância } \\
\text { do teste F (regressão) }\end{array}$ & $\mathrm{R}^{2}$ & \multicolumn{3}{c}{ Reação à mancha parda } \\
\\
\end{tabular}

Tabela 11. Distribuição de ligação dos marcadores que apresentaram efeito genético aditivo (D) ou efeito genético de dominância $(\mathrm{H})$ significativamente associado a diferenças fenotípicas para o nível de infecção de mancha parda no primeiro (NI1TF), segundo (NI2TF), terceiro (NI3TF) e quarto (NI4TF) trifólios e nível de infecção médio dos trifólios (NIMTF), avaliados em plantas da geração $F_{3: 2}$ originadas do cruzamento entre a cultivares de soja FT-2 e Davis, determinados por análise de variância univariada

\begin{tabular}{|c|c|c|c|c|c|c|c|c|}
\hline $\begin{array}{l}\text { Grupo de } \\
\text { Ligação }\end{array}$ & $\begin{array}{l}\text { Marcador } \\
\text { SSR }\end{array}$ & $\mathrm{P}$ & $\mathrm{R}^{2}$ & $\mathrm{D}^{1,3}$ & $\mathrm{H}^{3}$ & Média & $\mathrm{CV}$ & $h^{2}$ \\
\hline B2 & Satt168 & 0,027 & 0,063 & $43,999 * *$ & $0,580 \mathrm{~ns}$ & $\begin{array}{r}\text { NI1TF } \\
6,135 \\
\text { NI3TF }\end{array}$ & 39,841 & 0,73 \\
\hline D1b & Satt172 & 0,042 & 0,057 & $3,361 \mathrm{~ns}$ & $31,324 *$ & $\begin{array}{c}3,544 \\
\text { NIMTF }\end{array}$ & 65,016 & 0,69 \\
\hline B2 & Satt168 & 0,028 & 0,063 & $16,361 * *$ & $0,000 \mathrm{~ns}$ & 5,227 & 28,410 & 0,73 \\
\hline
\end{tabular}

${ }^{1}$ Estimado por análise de regressão

${ }^{3}$ Média do nível de infecção 


\subsubsection{Análises dos dados da população $\mathrm{F}_{4: 2}$}

Os marcadores identificados em associação com QTLs envolvidos na resistência a mancha parda avaliada nas progênies $\mathrm{F}_{4: 2}$ foram mapeados em três grupos distintos de ligação (LG) (Tabela 12): LG C2 (Satt277), LG K (Satt349) e LG J (Satt285, Satt431 e Satt596). O marcador Satt436 também apresentou associação significativa a um QTL, mas não foi possível incorporá-lo ao mapa genético de ligação.

O marcador Satt277, mapeado no grupo de ligação C2, apresentou associações significativas a QTLs em todos os trifólios avaliados e também foi detectado na média dos trifólios. Os níveis de infecção no segundo (NI2TF), terceiro (NI3TF) e médio dos trifólios (NIMTF) foram significativamente associados a marcadores mapeados no grupo de ligação J (LG J). No entanto, em cada um dos casos o marcador identificado foi diferente: Satt596 (NI2TF), Satt431 (NI3TF) e Satt285 (NIMTF). O marcador Satt436, não integrado ao mapa de ligação, foi associado a QTLs para NI1TF e NI2TF, enquanto que este último foi associado também ao marcador Satt349. A variação fenotípica explicada pelos marcadores associados a QTLs variou de 3,2\% a 9,2\% (Tabela 12). Os maiores valores de $\mathrm{R}^{2}$ resultaram da associação do marcador Satt277 aos QTLs envolvidos na determinação do NI1TF, NI2TF e NIMTF. Os valores de herdabilidade para o caráter variaram de $66 \%$ a $83 \%$, considerados altos para o caráter em estudo.

A maioria dos QTLs identificados nas análises de regressão foram detectados também nas análises de variância. Diferenças foram observadas entre as classes genotípicas dos marcadores Satt436 e Satt277 para o NI1TF, Satt277 para o NI2TF, Satt277 para o NI4TF e Satt277, Satt285 e Satt436 para o NIMTF, de acordo com o teste de comparação de médias de Tukey $(\mathrm{P} \leq 0,05)$. 
Tabela 12. Distribuição de ligação dos marcadores que apresentaram associação a diferenças fenotípicas para o nível de infecção de mancha parda no primeiro (NI1TF), segundo (NI2TF), terceiro (NI3TF) e quarto (NI4TF) trifólios e nível de infecção médio dos trifólios (NIMTF), avaliados em plantas da geração $F_{4: 2}$ originadas do cruzamento entre as cultivares de soja FT-2 $\left(\mathrm{A}_{1} \mathrm{~A}_{1}\right)$ e Davis $\left(\mathrm{A}_{2} \mathrm{~A}_{2}\right)$, determinadas por análise de regressão simples

\begin{tabular}{|c|c|c|c|c|c|c|}
\hline \multirow{2}{*}{$\begin{array}{c}\text { Grupos de } \\
\text { Ligação }\end{array}$} & \multirow{2}{*}{$\begin{array}{c}\text { Marcador } \\
\text { SSR }\end{array}$} & \multirow{2}{*}{$\begin{array}{r}\text { Nível de Significância } \\
\text { do teste F (Regressão) }^{1}\end{array}$} & \multirow{2}{*}{$\mathrm{R}^{2}$} & \multicolumn{3}{|c|}{ Reação à mancha parda ${ }^{3,4}$} \\
\hline & & & & $\mathrm{A}_{1} \mathrm{~A}_{1}{ }^{1}$ & $\mathrm{~A}_{1} \mathrm{~A}_{2}$ & $\mathrm{~A}_{2} \mathrm{~A}_{2}$ \\
\hline \multirow{4}{*}{$\begin{array}{l}\text { D1a (n.a) } \\
\quad \text { C2 }\end{array}$} & & & & \multicolumn{3}{|c|}{ NI1TF } \\
\hline & Satt436 & 0,015 & 0,051 & $3,896 \mathrm{a}$ & $3,486 \mathrm{ab}$ & $3,264 b$ \\
\hline & Satt277 & 0,003 & 0,075 & $3,285 \mathrm{c}$ & $3,533 b c$ & $4,242 \mathrm{a}$ \\
\hline & & & & \multicolumn{3}{|c|}{ NI2TF } \\
\hline D1a (n.a) & Satt436 & 0,050 & 0,032 & $4,167 \mathrm{a}$ & $3,762 \mathrm{a}$ & $3,648 \mathrm{a}$ \\
\hline $\mathrm{C} 2$ & Satt277 & 0,002 & 0,080 & $3,517 b$ & $3,881 \mathrm{ab}$ & $4,504 \mathrm{a}$ \\
\hline $\mathrm{K}$ & Satt349 & 0,026 & 0,045 & $4,208 \mathrm{a}$ & $3,819 \mathrm{a}$ & $3,414 \mathrm{a}$ \\
\hline \multirow[t]{2}{*}{$\mathrm{J}$} & Satt596 & 0,036 & 0,039 & $4,151 \mathrm{a}$ & $3,796 \mathrm{a}$ & $3,525 \mathrm{a}$ \\
\hline & & & & \multicolumn{3}{|c|}{ NI3TF } \\
\hline $\mathrm{C} 2$ & Satt277 & 0,050 & 0,033 & $4,156 \mathrm{a}$ & $4,553 \mathrm{a}$ & $4,633 a$ \\
\hline \multirow[t]{2}{*}{$\mathrm{J}$} & Satt431 & 0,033 & 0,041 & $4,226 \mathrm{a}$ & $4,383 \mathrm{a}$ & $4,789 \mathrm{a}$ \\
\hline & & & & \multicolumn{3}{|c|}{ NI4TF } \\
\hline \multirow[t]{2}{*}{$\mathrm{C} 2$} & Satt277 & 0,016 & 0,050 & $3,497 b$ & $3,882 \mathrm{ab}$ & $4,196 a$ \\
\hline & & & & \multicolumn{3}{|c|}{ NIMTF } \\
\hline D1a (n.a) & Satt436 & 0,035 & 0,038 & $4,194 \mathrm{a}$ & $3,759 b$ & $3,775 \mathrm{ab}$ \\
\hline $\mathrm{J}$ & Satt285 & 0,050 & 0,032 & $4,258 \mathrm{a}$ & $3,775 b$ & $3,821 \mathrm{ab}$ \\
\hline $\mathrm{C} 2$ & Satt277 & 0,001 & 0,092 & $3,613 b$ & $3,948 \mathrm{ab}$ & $4,394 a$ \\
\hline
\end{tabular}


Tabela 13. Distribuição de ligação dos marcadores que apresentaram efeito genético aditivo (D) ou efeito genético de dominância $(\mathrm{H})$ significativamente associados a diferenças fenotípicas para o nível de infecção de mancha parda no primeiro (NI1TF), segundo (NI2TF), terceiro (NI3TF) e quarto (NI4TF) trifólios e nível de infecção medio dos trifólios (NIMTF) avaliados em plantas da geração $F_{4: 2}$ originadas do cruzamento entre as cultivares de soja FT-2 e Davis, determinados por análise de variância univariada

\begin{tabular}{ccccccccc}
\hline $\begin{array}{c}\text { Grupo } \\
\text { de } \\
\text { Ligação }\end{array}$ & $\begin{array}{c}\text { Marcador } \\
\text { SSR }\end{array}$ & $\mathrm{P}$ & $\mathrm{R}^{2}$ & $\mathrm{D}^{1}$ & $\mathrm{H}$ & Média & $\mathrm{CV}$ & $\mathrm{h}^{2}$ \\
& & & & & & NI1TF & & \\
D1a & Satt436 & 0,046 & 0,053 & $6,894^{*}$ & $0,248 \mathrm{~ns}$ & 3,558 & 29,824 & 0,68 \\
C2 & Satt277 & 0,007 & 0,085 & $10,032^{* *}$ & $1,402 \mathrm{~ns}$ & 3,558 & 29,449 & 0,81 \\
& & & & & & NI2TF & & \\
J & Satt285 & 0,017 & 0,070 & $4,337 \mathrm{~ns}$ & $5,991^{*}$ & 3,861 & 28,637 & 0,76 \\
C2 & Satt277 & 0,008 & 0,083 & $11,757^{* *}$ & $0,443 \mathrm{~ns}$ & 3,852 & 28,525 & 0,80 \\
& & & & & & NI3TF & & \\
D1a & Satt436 & 0,040 & 0,056 & $2,875 \mathrm{~ns}$ & $3,739^{*}$ & 4,427 & 22,526 & 0,70 \\
J & Satt285 & 0,032 & 0,059 & $2,997 \mathrm{~ns}$ & $4,040^{*}$ & 4,427 & 22,484 & 0,72 \\
& & & & & & NI4TF & & \\
C2 & Satt277 & 0,050 & 0,050 & $6,399^{*}$ & $0,014 \mathrm{~ns}$ & 3,768 & 27,555 & 0,66 \\
& & & & & & NIMTF & & \\
D1a & Satt436 & 0,040 & 0,055 & $3,214^{*}$ & $1,431 \mathrm{~ns}$ & 3,902 & 21,465 & 0,70 \\
J & Satt285 & 0,038 & 0,056 & $2,698^{*}$ & $2,010 \mathrm{~ns}$ & 3,902 & 21,456 & 0,70 \\
C2 & Satt277 & 0,004 & 0,093 & $7,745^{* *}$ & $0,082 \mathrm{~ns}$ & 3,901 & 21,125 & 0,83 \\
\hline Estimado por análise de regressão & & & & & &
\end{tabular}

\subsubsection{Análise de mapeamento por intervalo}

Utilizando os dados da população $\mathrm{F}_{3: 2}$, um intervalo foi detectado entre os marcadores Satt349 e Satt475 no grupo de ligação K, o qual apresentou um efeito significativo $(\mathrm{P} \leq 0,01)$ na expressão fenotípica do NI1TF, com valor de LOD de 2,665. A contribuição do QTL putativo para o caráter foi de 39,7\% e, mesmo com este efeito considerável sobre o caráter, este não foi detectado nas análises de regressão e variância realizadas para o NI1TF.

Quando se utilizou os dados da população $\mathrm{F}_{4: 2}$ um outro intervalo significativo foi identificado entre os marcadores Satt277 e Satt079 no grupo de ligação C2 e foi 
significativamente associado ao NI1TF, NI2TF e NIMTF, com valores de LOD de 2,224, 2,176 e 2,436, respectivamente. As variações explicadas por este QTL identificado foram de $8,6 \%$ para o NI1TF, 8,4\% para o NI2TF e 9,3\% para o NIMTF, valores muito próximos aos obtidos nas análises de regressão para esse marcador (Tabela 12).

As análises de mapeamento por intervalo nas duas populações identificaram somente uma região genômica associada ao caráter similar à encontrada pelas análises de regressão. Trata-se do QTL situado entre os marcadores Satt277 e Satt079, associado a NI1TF, NI2TF e NIMTF. Nestes três casos, as análises de regressão indicaram significância do marcador Satt277 (Tabela 12). A discrepância entre o número de QTLs identificados pode estar relacionada aos diferentes níveis de significância adotados na análise de regressão e na análise de mapeamento por intervalo( $\mathrm{P} \leq 0,05$ e $\mathrm{P} \leq 0,01$, respectivamente). Outra explicação poderia ser a sensibilidade dos métodos para detectar QTLs, pois os resultados obtidos nas análises de regressão se aproximam daqueles obtidos pelo mapeamento por intervalo quando o QTL está localizado muito próximo ao loco marcador (Lander \& Botstein, 1989). Este fato pôde ser observado quando o QTL foi identificado exatamente entre os marcadores Satt349 e Satt475 (LG K) e não foi detectado nas análises de regressão e variância. O QTL identificado no intervalo entre Satt277 e Satt079 (LG C2) estava localizado muito próximo ao marcador Satt277, resultando na significância tanto na análise de regressão como na análise de variância. Ainda, uma outra explicação seria a baixa saturação do mapa de ligação para a detecção dos QTLs com o mapeamento por intervalo, sendo a maioria dos intervalos entre marcadores maiores que $15 \mathrm{cM}$. 


\subsection{Conclusões}

O número de marcadores microssatélites utilizado não foi suficiente para realizar a cobertura satisfatória do genoma, fato que prejudicou a identificação dos QTLs envolvidos na resistência, principalmente quando se realizou o mapeamento por intervalo, devido à distância entre os marcadores no mapa de ligação.

Os QTLs identificados explicaram uma pequena porcentagem da variação fenotípica do caráter, predominando os efeitos aditivos.

Não houve correspondência entre os QTLs identificados nas gerações segregantes $F_{3: 2}$ e $F_{4: 2}$. Dois QTLs foram detectados com maior freqüência nos experimentos: Satt168 (LG B2) nas avaliações da geração $F_{3: 2}$ e Satt277 (LG C2) nas avaliações da geração $F_{4: 2}$. Essa informação é importante para direcionar estudos futuros da resistência da soja à mancha parda, priorizando esses grupos de ligação. 


\section{CONCLUSÕES GERAIS}

As metodologias utilizadas nesse trabalho foram satisfatórias e garantiram a qualidade dos dados obtidos, mesmo com um número reduzido de marcadores moleculares polimórficos.

O mapeamento do gene de resistência à ferrugem asiática da soja da fonte utilizada nesse trabalho foi a etapa inicial de estudos mais detalhados para a identificação de marcadores fortemente ligados e, também, para o mapeamento de outros genes de resistência à ferrugem.

$\mathrm{O}$ fato do mapeamento do gene de resistência à ferrugem e de um QTL envolvido na determinação da resistência à septoriose no mesmo grupo de ligação reforça a hipótese de que os genes de resistência a doenças em plantas devem estar organizados em blocos (clusters) no genoma.

Pesquisas futuras são recomendadas para se ampliar a cobertura do genoma da soja com um número maior de marcadores moleculares e, assim, melhorar o entendimento das bases genéticas desses patossistemas. 


\section{REFERÊNCIAS BIBLIOGRÁFICAS}

AKKAYA, M.S.; BHAGWAT, A.A.; CREGAN, P.B. Lenght polymorphisms of simple sequence repeat DNA in soybean. Genetics, v.132, p.1131-1139, 1992.

AKKAYA, M.S.; SHOEMAKER, R.C.; SPECHT, J.E.; BHAGWAT, A.A.; CREGAN, P.B. Integration of simple sequence repeat DNA markers into a soybean linkage map. Crop Science, v.35, p.1439-1445, 1995.

ALMEIDA, A.M.R. Ação de diferentes temperaturas e regimes de luz sobre a germinação de esporos de Septoria glycines Hemmi. Fitopatologia Brasileira, v.3, p.211-214, 1978 .

ALMEIDA, A.M.R. Efeito da inoculação de Septoria glycines Hemmi em plantas de soja (Glycine max (L.) Merrill) em quatro estádios de desenvolvimento. Fitopatologia Brasileira, v.5, p.163-168, 1980.

ALMEIDA, A.M.R.; MONDARDO, A.; DERPSH, R.; LAFFRANCHI, J.H. Importância de espécies vegetais de inverno, utilizadas em adubação verde, como possíveis hospedeiras de patógenos de soja. Fitopatologia Brasileira, v.6, n.1, p.109-113. 1981.

ARAHANA, V.S.; GRAEF, G.L.; SPECHT, J.E.; STEADMAN, J.R.; ESKRIDGE, K.M. Identification of QTLs for resistance to Sclerotinia sclerotiorum in soybean. Crop Science, v.41, p.180-188, 2001. 
ARIAS, C.A.A.; BROGIN, R.L.; TOLEDO, J.F.F.; YORINORI, J.T.; OLIVEIRA, M.F. Caracterização da reação de genótipos de soja à mancha parda em casa-devegetação. In: CONGRESSO BRASILEIRO DE SOJA, Londrina, 1999. Anais. Londrina: Embrapa Soja, 1999. p.468.

ARIAS, C.A.A.; BROGIN, R.L.; YORINORI, J.T.; KIIHL, R.A. de S.; TOLEDO, J.F.F. de. Um gene dominante determinando a resistência da cultivar FT-2 à ferrugem da soja (Phakopsora pachyrhizi Sydow). In: CONGRESSO BRASILEIRO DE MELHORAMENTO DE PLANTAS, 2.; Porto Seguro, 2003. Anais. Porto Seguro: Sociedade Brasileira de Melhoramento de Plantas - SBMP, 2003. (compact disc)

BACHMAN, M.S.; TAMULONIS, J.P.; NICKELL, C.D.; BENT, A.F. Molecular markers linked to brown stem rot resistance genes, [Rbs.sub.1] and [Rbs.sub.2], in soybean. Crop Science, v.41, n.2, p.527-535, 2001.

BACKMAN, P.A.; RODRIGUES-KABANA, R.; HAMMOND, L.M.; THURLOW, D.L. Cultivar, environment, and fungicide effects on foliar disease losses in soybeans. Phytopathology, v.69, p.562-564, 1979.

BASU, P.K.; BUTLER, G. Assessment of brown spot (Septoria glycines) alone and in combination with bacterial blight (Pseudomonas syringae pv. Glycinea) on soybeans in a short-season area. Canadian Journal of Plant Pathology, v.10, p.78$82,1988$.

BEDENDO, I.P. Ferrugens. In: BERGAMIN FILHO, A.; KIMATI, H.; AMORIM, L. (Ed.). Manual de Fitopatologia. 3.ed. São Paulo: Agronômica Ceres, 1995. 919p.

BENEDICT, W.G. Studies on the effect of Pseudomonas glycinea on Septoria glycines development foliage of the Harosoy soybean growth under controlled environmental conditions. Canadian Journal of Botany, v.42, p.1135-1141, 1964.

BERNARD, R.L. Breeding soybeans for resistance to foliar diseases. IN: CONFERENCIA MUNDIAL DE INVESTIGACIÓN EN SOJA, 4., Buenos Aires, 1989. Actas. Buenos Aires: AASOJA, 1989. p.1138-1143. 
BONATO, E.R.; BONATO, A.L.V. A Soja no Brasil: historia e estatística. Londrina: EMBRAPA / CNPSo, 1987. 61p. (Documentos, 21)

BONDE, M.R.; BROWN, M.F. Morphological comparison of isolates of Phakopsora pachyrhizi from different areas of the world. Canadian Journal of Microbiology, v.26, p.1443-1449, 1980.

BROGIN, R.L. Controle genético da resistência da soja à mancha parda (Septoria glycines). Londrina, 2001. 84p. Tese (Mestrado) - Universidade Estadual de Londrina.

BROGIN, R.L.; ARIAS, C.A.A.; KIIHL, R.A.S.; TOLEDO, J.F.F.; YORINORI, J.T. Genótipos de soja resistentes a ferrugem asiática da soja (Phakopsora pachyrhizi). In: CONGRESSO BRASILEIRO DE MELHORAMENTO DE PLANTAS, 2., Porto Seguro, 2003. Anais. Porto Seguro: Sociedade Brasileira de Melhoramento de Plantas - SBMP, 2003a. (compact disc)

BROGIN, R.L; ARIAS, C.A.A; TOLEDO, J.F.F. Genetic control of soybean resistance to Brown spot (Septoria glycines): first studies. Crop Breeding and Applied Biotechnology, v.3, n.1, p.35-44, 2003 b.

BROGIN, R.L.; ARIAS, C.A.A.; YORINORI, J.T. Tolerância de cultivares de soja à mancha parda (Septoria glycines), em casa-de-vegetação e a campo. In: CONGRESSO NACIONAL DE GENÉTICA, 45., Gramado, 1999. Anais. Gramado: Sociedade Brasileira de Genética - SBG, 1999. p.674-675.

BROMFIELD, K.R. Soybean rust and soybean rust research. Soybean Genetics Newsletter, v.1, p.45-52, 1974.

BROMFIELD, K.R.; HARTWIG, E.E. Resistance to soybean rust and mode of inheritance. Crop Science, v.20, p.254-255, 1980.

BROMFIELD, K.R.; YANG, C.Y. Soybean rust: Summary of available knowledge. In: GOODMAN, R.M. (Ed.). Expanding the uses of soybean. Urbana-Champaign: University of Illinois, 1976 (INTSOY Series, 10).

BURDON, J.J. Major gene resistance to Phakopsora pachyrhizi in Glycine canescens, a wild relative of soybean. Theoretical and Applied Genetics, v.75, p.923-928, 1988. 
BURDON, J.J.; MARSHALL, D.R. Evaluation of Australian native species of Glycine for resistance to soybean rust. Plant Disease, v.65, p.44-45, 1981.

CAPELlARI Junior, L.; RODRIGUES, R.R.; SOUZA, V.C. Apostila de botânica sistemática. Piracicaba: Departamento de Botânica, ESALQ/USP, 1999. 95 p.

CHANG, S.J.C.; DOUBLER, T.W.; KILO, V.; ABU-THREDEIH, J.; PRAHBU, R.; FREIRE, V.; SUTTNER, R.; KLEIN, J.; SCHMIDT, M.E.; GIBSON, P.T.; LIGHTFOOT, D.A. Association of loci underlying field resistance to soybean sudden death syndrome (SDS) and cyst nematode $(\mathrm{SCN})$ race 3. Crop Science, v.37, p.965-971, 1997.

CHANG, S.J.C.; DOUBLER, T.W.; KILO, V.; SUTTNER, R. SCHMIDT, M.E.; GIBSON, P.T.; LIGHTFOOT, D.A. Two additional loci underlying durable field resistance to soybean sudden death syndrome (SDS). Crop Science, v.36, p.1684-1688, 1996.

CHUnWOngSe, J.; CHUnWOngSe, C.; RAXSAPAN, A.; POKEPRASERT, A.; PANITCHAYATHUM, N.; PHUMICHAI, C.; NUNTAPUNT, M.; DANGPRADUB, S.; TEPJUN, V.; SRISOMBUN, S. Identification of DNA marker associated with soybean rust resistance. In: WORLD SOYBEAN RESEARCH CONFERENCE, 7., Foz do Iguaçu, 2004. Proceedings. Londrina: Embrapa Soja, 2004. p.318.

CHURCHILL, G.A.; DOERGE, R.W. Empirical threshold values for quantitative trait mapping. Genetics, v.138. p.963-971, 1994.

COMPANHIA NACIONAL DE ABASTECIMENTO. Indicadores da Agropecuária. Estimativa de Safras - Levantamento Safra 2004/2005. Disponível em: http://www.conab.gov.br/download/Safra/4levantamentoPlantio.doc

CONCIBIDO, V.; BOUTIN, S.; DENNY, R.; HAUTEA, R.; ORF, J.; YOUNG, N.D. Genome mapping of a soybean cyst nematode resistance gene in Peking, PI 91763, and PI 88788 using DNA markers. Crop Science, v.37, p.258-264, 1997. 
COOPER, R.L. Soybean yield response to benomil fungicide application under maximum yield conditions. Agronomy Journal, v.81, p.847-849, 1989.

CORNELIOUS, BK.; SNELLER, CH. Yield and molecular diversity of soybean lines derived from crosses of Northern and Southern elite parents. Crop Science, v.42, p.642-647, 2002.

COX, T.S.; KIANG, Y.T.; GORMAN, M.B.; RODGERS, D.M. Relationships between coefficient of parentage and genetic similarity indices in soybeans. Crop Science, v.25, p.529-532, 1985.

CREGAN, P.B.; JARVIK, T.; BUSH, A.L.; SHOEMAKER, R.C.; LARK, K.G.; KAHLER, A.L.; KAYA, N.; VANTOAI, T.T.; LOHNES, D.G.; CHUNG, J.; SPECHT, J.E. An integrated genetic linkage map of the soybean genome. Crop Science, v.39, p.1464-1490, 1999.

DIERS, B.W.; MANSUR, L.; IMSANDE, J.; SHOEMAKER, R.C. Mapping Phytophthora resistance loci in soybean with restriction fragment length polymorphism markers. Crop Science, v.32, p.377-383, 1992.

DOERGE, R.W.; CHURCHILL, G.A Permutation tests for multiple loci affecting a quantitative character. Genetics, v.142, p.285-294, 1996.

DUDLEY, J.W. Molecular markers in plant improvement: manipulation of genes affecting quantitative trait. Crop Science, v. 33, p.660-668, 1993.

EDWARDS, M.D.; STUBER, C.W.; WENDEL, J.F. Molecular-marker facilitated investigations of quantitative trait loci in maize. I. Numbers, genomic distribution and types of gene action. Genetics, v. 116, p.113-125, 1987.

EMPRESA BRASILEIRA DE PESQUISA AGROPECUÁRIA. Sistema de Alerta da Embrapa Soja, 2005. Disponível em: www.cnpso.embrapa.br/alerta

FEDERER, W.T. Experimental Design: Theory and Application. New York: Mac Milan, 1965. 544p.

FEHR, W.R.; CAVINESS, C.E. Stage of soybean development. Ames: Iowa State University, 1981. 12p. (Iowa Cooperative Extensive Service. Special Report, 80). 
FERREIRA, A.R.; FOUTZ, K.R.; KEIM, P. Soybean genetic map of RAPD markers assigned to an existing scaffold RFLP map. Journal of Heredity., v.91, p.392-396, 2000.

FERREIRA, M.E.; GRATTAPAGLIA, D. Introdução ao uso de marcadores moleculares em análises genéticas. 3.ed. Brasília: EMBRAPA-CENARGEN, 1998. 220p.

FISCHER, A.M.; DUBBS, W.E.; BAKER, R.A.; FULLER, M.A.; STEPHENSON, L.C.; GRIMES, H.D. Protein dynamics, activity and cellular localization of soybean lipoxygenases indicate distinct functional roles for individual isoforms. The Plant Journal, v.19, n.5, p.543-554, 1999.

GUIMARÃES, C.T.; MOREIRA, M.A. Genética molecular aplicada ao melhoramento de plantas. In: BORÉM, A. (Ed.). Melhoramento de espécies cultivadas. Viçosa: UFV, 1999. p.715-740.

HARTMAN, G.L.; LEE, G.B. Velvetleaf as a host for Septoria glycines. Plant Disease, v.79, p.426, 1995.

HARTMAN, G.L.; SINCLAIR, J.B.; RUPE, J.C. Compendium of soybean diseases. 4.ed. St. Paul, Minnesota: The American Phytopathological Society, 1999. 128p.

HARTMAN, G.L.; WANG, T.C.; SHANMUGASUNDARAM, S. Soybean Rust Research: Progress and Future Prospects. In WORLD SOYBEAN RESEARCH CONFERENCE, 5., Bangkok, 1997. Proceedings. Chiang Mai: Kasetsart University Press, 1997. p.180-186.

HARTMAN, G.L.; WANG, T.C.; TSCHANZ, A.T. Soybean rust development and the quantitative relationship between rust severity and soybean yield. Plant Disease, v.75, p.596-600, 1991.

HARTWIG, E.E. Identification of a fourth major gene conferring resistance to soybean rust. Crop Science, v.26, p.1135-1136, 1986.

HARTWIG, E.E.; BROMFIELD, K.R. Relationships among three genes conferring specific resistance to rust in soybeans. Crop Science, v.23, p.237-239, 1983. 
HEMMI, T. A new brown-spot disease of the leaf of Glycine hispida Maxim caused by Septoria glycines. Transaction of the Sapporo Natural History Society, v.6, p.1217. 1915.

HIROMOTO, D.M; VELLO, N.A. The genetic base of Brazilian soybean (Glycine max (L.) Merrill) cultivars. Revista Brasileira de Genética, v.9, p.295-306, 1986.

JANSEN. R.C. Interval mapping of multiple quantitative trait loci. Theoretical and Applied Genetics, v.79, p.583-592, 1993.

KAMICKER, T.A.; LIM, S.M. Field evaluation of pathogenic variability in isolates of Septoria glycines. Plant Disease, v.69, p.744-746, 1985.

KANAZIN, V; MAREK, L.F; SHOEMAKER, R.C. Resistance gene analogs are conserved and clusteres in soybean. Proceedings of the National Academy of Sciences of USA, v.93, p.11746-11750, 1996.

KAO, C.H.; ZENG, Z.B.; TEASDALE, R.D. Multiple interval mapping for quantitative trait loci. Genetics, v.152, p.1203-1216, 1999.

KARIAPPER, M.S; DUNHAM, W.R; FUNK Junior, M.O. Iron extraction from soybean lipoxygenase 3 and reconstitution of catalytic activity from the apoenzyme. Biochemical and Biophysical Research Communications, v.284, n.3, p.563-567, 2001.

KATO, K.K.; PALMER, R.G. Molecular mapping of four ovule lethal mutants in soybean. Theoretical and Applied Genetics, v.108, p.577-585, 2003.

KAWUKI, R.S.; TUKAMUHABWA, P.; ADIPALA, E. Soybean rust severity, rate of rust development, and tolerance as influenced by maturity period and season. Crop Protection, v.23, p.447-455, 2004.

KEIM, P; OLSON, T.C; SHOEMAKER, R.C. A rapid protocol for isolating soybean DNA. Soybean Genetics Newsletter, v.15, p.150-152, 1988.

KILEN, T.C. Identification of a soybean breeding line resistant to rust in the Philippines. Soybean Genetics Newsletter, v.24, p 199-200, 1997.

LANDE, R.; THOMPSON, R. Efficiency of rnarker-assisted selection $o$ the improvement of quantitative traits. Genetics, v.124, p.743-756, 1990. 
LANDER, E.S.; BOTSTEIN, D. Mapping mendelian factors underlying quantitative traits using RFLP linkage maps. Genetics, v.121, p.185-199, 1989.

LANDER, E.S; GREEN, P; ABRAHAMSON, J; BARLOW, A; DALY, M.J; LINCOLN, S.E; NEWBURG, L. MAPMAKER: an interactive computer program for constructing genetic linkage maps of experimental and natural populations. Genomics, v.1, p.174-181, 1987.

LEE, G.B.; HARTMAN, G.L. Reactions of Glycines species and other legumes to Septoria glycines. Plant Disease, v.80, p.90-94, 1996.

LEWIN, B. Genes VII, Porto Alegre: Artmed Editora, 2001.955p.

LI, Z.; NELSON, R.L. Genetic diversity among soybean accessions from three countries measured by RAPDs. Crop Science, v.41, p.1337-1347, 2001.

LIM, S.M. Evaluation of soybean for resistance to septoria brown spot. Plant Disease Report, v.63, p.242-245, 1979.

LIM, S.M. Brown spot severity and yield reduction in soybean. Phytopathology, v.70, p.974-977, 1980.

LIM, S.M.; HYMOWITZ, T. Reactions of perennial wild species of genus Glycine to Septoria glycines. Plant Disease, v.71, p.891-893, 1987.

LINCOLN, S.E., DALY, M.J., LANDER, E.S. Constructing genetic linkage maps with Mapmaker/Exp version 3.0 and mapping genes controlling quantitative traits using Mapmaker/QTL, version 1.1. A Tutorial and Reference Manual. Cambridge, MA: Whitehead Institute for Biomedical Research, 1993. 73p.

LUZZARDI, G.C.; JUN, G.B.; WETZEL, D.P.; GASTAL, M.F.; RAUPP, C. Mancha Castanha da Soja, uma nova doença no Brasil. IPEAS - Indicação de Pesquisa, v.33, p.1-3, 1972.

LYNCH, M.; WALSH, B. Genetics and analysis of quantitative genetics. Sunderland, Massachusetts: Sinauer Associates, 1997. 990p. 
MacARTHUR, J.D. Linkage groups in tomato. Journal of Genetics, v.29, p.123-133, 1934.

MacGREGOR, T.; BHATTACHARYYA, M.; TYLER, B.; BHAT, R.; SCHMITTHENNER, A.F.; GIJZEN, M. Genetic and physical mapping of Avr1a in Phytophthora sojae. Genetics, v.160, p.949-959, 2002.

MacNEILL, B.H. ; ZALASKY, H. Histological study of host-parasite relationships between Septoria glycines Hemmi and soybean leaves and pods. Canadian Journal of Botany, v.35, p.501-505, 1957.

MANANDHAR, J.B.; JOSHI, S. Soybean rust in Nepal. Phytopathology, v.7, n.5, p. $843,1983$.

MANSUR, L.M.; ORF, J.H.; CHASE, K.; JARVIK, T.; CREGAN, P.B.; LARK, K.G. Genetic mapping of agronomic trait using recombinant inbred lines of soybean. Crop Science, v.36, p.1327-1336, 1996.

MEKSEM, K.; DOUBLER, T.W.; CHANCHAROENCHAI, K.; NJITI, V.; CHANG, S.J.C.; RAO-ARELLI, A.P.; CREGAN, P.; GRAY, L.E.; GIBSON, P.T.; LIGHTFOOT, D.A. Clustering among loci underlying soybean resistance to Fusarium solani, SDS and SCN in near-isogenic lines. Theoretical and Applied Genetics, v.99, p.1131-1142, 1999.

MELCHING, J.S.; DOWLER, W.M.; KOOGLE, D.L.; ROYER, M.H. Effects of duration, frequency and temperature of leaf wetness periods on soybean rust. Plant Disease, v.73, p.117-122, 1989.

MESSMER, M.M.; MELCHINGER, A.E.; HERMANN, R.G.; BOPPERMAIER, J. Relationships among early European maize inbreds: II. Comparison of pedigree and RFLP data. Crop Science, v.33, p.944-950, 1993.

McLEAN, R.J.; BYTH, D.E. Inheritance of resistance to rust (Phakopsora pachyrhizi) in soybeans. Australian Journal of Agricultural Research, v.31, p.951-956, 1980. 
MIAN, M.A.R.; WANG, T.Y, PHILLIPS, D.V; ALVERNAZ, J.; BOERMAN, H.R. Molecular mapping of the Rcs3 gene for resistance to frogeye leaf spot in soybean. Crop Science, v.39, n.6, p.1687-1691, 1999.

MORGAN, T.H. Sex- linked inheritance in Drosophila. Science, v.32, p.120-122, 1910.

MOSS, D.W. Isoenzymes. New York: Chapman \& Hall, 1982. 199p.

MÜLLER, L. Morfologia, Anatomia e Desenvolvimento. In: MIYASAKA, S.; MEDINA, J.C. (Ed.). A Soja no Brasil. Campinas: Instituto de Tecnologia de Alimentos, 1981. p.73-104.

MULLIS, K.B. The unusual origin of the polimerase chain reaction. Scientific American, v.262, p.56-65, 1990.

NJITI, V.N.; SCHMIDT, C.A.; SCHMIDT, M.E.; LIGHTFOOT, D.A. Mapping loci underlying yield in Illinois. Soybean Genetics Newsletter, v.24, p.136138, 1997.

OGLE, H.J.; BYTH, D.E.; McLEAN, R.J. Effect of rust (Phakopsora pachyrhizi) on soybean yield and quality in south-eastern Queensland. Aust. Journal of Agricultural Research, v.30, p.883-893, 1979.

OLIVEIRA, J.E.D. Valor da Soja como Alimento. In: MIYASAKA, S.; MEDINA, J.C. A Soja no Brasil. Campinas: Instituto de Tecnologia de Alimentos, 1981. p.820-823.

ONO, Y.; BURITICA, P.; HENNEN, J.F. Delimitation of Phakopsora, Physopella and Cerotelium and their species on Leguminosae. Mycology Research, v.96, p.825$850,1992$.

PATAKY, J.K; LIM, S.M. Effects of septoria brown spot on the yield components of soybeans. Plant Disease, v.65, p.588-590, 1981.

PATERSON, A.H. Genome mapping in plants. New York: Academic Press, 1996. $330 \mathrm{p}$. 
PATERSON, A.; LANDER, E.; LINCOLN, S.; HEWITT, J. PATERSON, S.; TANKSLEY, S. Resolution of quantitative traits into Mendelian factors using a complete RFLP linkage map. Nature, v.335, p.721-726, 1988.

PICININI, E.C.; COSTA NETO, J.P. Influência do pH, temperatura e regime luminoso na obtenção do inóculo de Septoria glycines Hemmi. Agronomia Sulriograndense, v.15, p.199-208, 1979.

POLZIN, K.M, LOHNES, D.G; NICKELL, C.D; SHOEMAKER, R.C. Integration of Rps2, Rmd and Rj2 into linkage group J of the soybean molecular map. Journal of Heredity, v.85, p.300-303, 1994.

REYNA, N.; SNELLER, C.H. Evaluation of Marker-Assisted Introgression of Yield QTL Alleles into Adapted Soybean. Crop Science, v.41, p.1317-1321, 2001.

RITCHIE, S.; HANWAY, J.J.; THOMPSON, H.E. How a soybean plant develops. Ames: Iowa State University of Science and Technology, 1982. 20p. (Special Report, 53)

ROSS, J.P. Effect of simulated dew and postinoculation moist periods on infection of soybean by Septoria glycines. Phytopathology, v.72, p.236-238, 1982.

SAMBROOK, J.; FRITSCH, E. F.; MANIATIS, T. Molecular cloning: a laboratory manual. 2.ed. New York: Cold Spring Harbor Press, 1989.

SAS INSTITUTE. SAS OnlineDoc®: version 8. Cary, 1999.

SCHOEN, D.J.; BURDON, J.J.; BROWN, A.D.H. Resistance of Glycine tomentella to soybean leaf rust Phakopsora pachyrhizi in relation to ploidy level and geographic distribution. Theoretical and Applied Genetics, v.83, p.827-832, 1992.

SCHUSTER, I.; ABDELNOOR, R.V.; MARIN, S.R.R, CARVALHO, V.P.; KIIHL, R.A.S.; SILVA, J.F.V.; SEDIYAMA, C.S.; BARROS, E.G.; MOREIRA, M.A. Theoretical and Applied Genetics, v.102, n.1, p.91-96, 2001.

SEDIYAMA, T.; PEREIRA, M.G.; SEDIYAMA, C.S.; GOMES, J.L. Cultura da Soja. Viçosa: UFV, 1985. 96p. 
SINCLAIR, J.B.; HARTMAN, G.L. (Eds.) Soybean Rust Workshop. Urbana, 1996.

Proceedings. Urbana: National Soybean Research Laboratory, 1996.

SKRZYPCZAK-JANKUN, E.; AMZEL, L.M.; KROA, B.A.; FUNK Junior, M.O.

Structure of soybean lipoxygenase L3 and a comparison with its L1 isoenzyme.

Proteins, v.29, n.1, p.15-31, 1997.

SONG, Q.J.; MAREK, L.F.; SHOEMAKER, R.C.; LARK, K.G.; CONCIBIDO, V.C.;

DELANNAY, X.; SPECHT, J.E.; CREGAN, P.B. A new genetic linkage map for soybean. Theoretical and Applied Genetics, v.109, p.122-128, 2004.

STEEL, R.G.D; TORRIE, J.H. Principles and procedures of statistics. New York: McGraw Hill Book, 1960. 48p.

TAN, Y.J.; YU, Z.L.; LIU, J.L. Studies on the epidemic regulation and control of soybean rust caused by Phakopsora pachyrhizi Sydow. Urbana-Champaign: University of Illinois, 1983. p.169-174. (INTSOY Series)

TANKSLEY, S.D. Mapping polygenes. Annual Review of Genetics, v.27, p.205-233, 1993.

THOMPSON, J.A.; NELSON, R.L. Core set of primers to evaluate genetic diversity in soybean. Crop Science, v.38, p.1356-1362, 1998.

THOMPSON, J.A.; NELSON, R.L.; VODKIN, L.O. Identification of diverse soybean germplasm using RAPD markers. Crop Science, v.38, p.1348-1355, 1998.

TISSELI, O.; SINCLAIR, J.B. ; HYMOWITZ, T. Sources of resistance to selected fungal, bacterial, viral and nematodes diseases of soybeans - Brown spot. Urbana-Champaign: University of Illinois, 1980. p.7-8. (INTSOY International Soybean Program Series Number 18)

TSCHANZ, A.T.; SHANMUGASUNDARAM, S. Soybean rust. In: WORLD SOYBEAN RESEARCH CONFERENCE , 3., Boulden, 1984. Proceedings. Boulden: Westview Press, 1984. p.562-567.

TSCHANZ, A.T.; TSAI, B.Y. Evidence of tolerance to soybean rust in soybeans. Soybean Rust Newsletter, v.6, p.28-31, 1983. 
TSCHANZ, A.T.; WANG, T.C.; HU, L.F. Epidemic development of soybean rust and a partial characterization of resistance to soybean rust. Soybean Rust Newsletter, v.3, p.35-41, 1980.

TSCHANZ, A.T.; WANG, T.C.; TSAI, B.Y. Recent advances in soybean rust research at AVRDC. In: SHANMUGASUNDARAM, S.; SULZBERGER, E.W. (Ed.) SYMPOSIUM ON SOYBEANS IN TROPICAL AND SUBTROPICAL CROPPING SYSTEMS, Tsukuba, 1983. Proceedings. Shanhua: Asian Vegetable Research and Development Center - AVRDC, 1985. p.237-245.

VAKILI, N.G. Field survey of endemic leguminous hosts of Phakopsora pachyrhizi in Puerto Rico. Plant Disease Report, v.63, p.931-935, 1979.

VALE, F.X.R. do; CHAVES, G.M.; ZAMBOLIM, L. Effect of planting time on the incidence of soybean rust. Soybean Rust Newsletter, v.7, p.4-6, 1985a.

VALE, F.X.R. do; CHAVES, G.M.; ZAMBOLIM, L. Host range study of soybean rust in Brazil. Soybean Rust Newsletter, v.7, p.7-9, 1985 b.

VELLO, N.A., BROGIN, R.L.; ARIAS, C.A.A. Estrategias de melhoramento para o controle da ferrugem da soja. Anais do II Congresso Brasileiro de Soja e Mercosoja 2002. Foz do Iguazú. PR. Brasil. pp 188-196.

VENKOVSKY, R; BARRIGA, P. Genética biométrica no fitomelhoramento. Ribeirão Preto: Revista Brasileira de Genética, 1992. 496p.

VOGL, C; XU, S. Multipoint mapping of viability and segregation distorting loci using molecular markers. Genetics, v.155, p.1439-1447, 2000.

WEBB, D.M.; BALTAZAR, B.M.; RAO-ARELLI, A.P.; SCHUPP, J.; CLAYTON, K.; KEIM, P.; BEAVIS, W.D. Genetic mapping of soybean cyst nematode race-3 resistance loci in the soybean PI 437654. Theoretical and Applied Genetics, v.91, p.574-581, 1995.

WELSH, J.; McCLELLAND, M. Fingerprinting genomes using PCR with arbitrary primers. Nucleic Acids Research, v.18, p.7213-7218, 1990.

WILLIANS, D.J.; NYVALL, R.F. Leaf infection and yield losses caused by brown spot and bacterial blight diseases of soybean. Phytopathology, v.70, p.900-902, 1980. 
WILLIAMS, J.G.; KUBELIK, A.R.; LIVAK, K.J.; RAFALSKIU, L.A.; TINGEY, S.V. DNA polymorphism amplified by arbitrary primers are useful as genetic markers. Nucleic Acids Research, v.18, p.6531-6535, 1990.

WOLF, F. A. LEHMAN, S. G. Brown spot disease of soybean. Journal of Agricultural Research, v.33, p.365-374, 1926.

WRATHER, J.A.; ANDERSON, T.R.; ARSYAD, D.M.; GAI, J.; PLOPER, L.D.; PORTA-PUGLIA, A.; RAM, H.H.; YORINORI, J.T. Soybean disease loss estimates for the top 10 soybean producing countries in 1994. Plant Disease, v.81, p.107-110, 1997.

XU, B.; ZHEN, H.; LU, Q.; ZHAO, S. Three new evidences of the original area of soybean. IN: WORLD SOYBEAN RESEARCH CONFERENCE, 4., Buenos Aires, 1989. Proceedings. Bueno Aires: Gráfica Editora SRL, 1989. p.124-128.

XU, Y.; ZHU, L.; XIAO, J; et al. Chromosomal regions associated with segregation distortion of molecular markers in $\mathrm{F}_{2}$, backcross, doubled haploid, and recombinant inbred populations in rice (Oryza sativa L.). Molecular \& General Genetics, v.253, p.535-545, 1997.

YAMANAKA, N.; NINOMIYA, S.; HOSHI, M.; TSUBOKURA, Y.; YANO, M.; NAGAMURA, Y.; SASAKI, T.; HARADA, K. An informative linkage map of soybean reveals QTLs for flowering time, leaflet morphology and regions of segregation distortion. DNA Research, v.8, p.61-72, 2001.

YANG, W.; WEAVER, D.B.; NIELSEN, B.L.; QIU, J. Molecular mapping of a new gene for resistance to frogeye leaf spot of soya bean in "Peking". Plant Breeding, v.120, n.1, p.73-78, 2001.

YORINORI, J.T. Avaliação do efeito das doenças de final de ciclo ao nível de lavoura. In: EMPRESA BRASILEIRA DE PESQUISA AGROPECUÁRIA. Resultados de Pesquisa de Soja 1985/86. Londrina: EMBRAPA, Centro Nacional de Pesquisa de Soja, 1987a. p.205-208. 
YORINORI, J.T. Determinação do grau de tolerância a doenças de final de ciclo em cultivares de soja. In: EMPRESA BRASILEIRA DE PESQUISA AGROPECUÁRIA. Resultados de Pesquisa de Soja 1985/86. Londrina: EMBRAPA, Centro Nacional de Pesquisa de Soja, 1987b. p.208-210.

YORINORI, J.T. Soybean diseases and yield loss assessment in Brazil. IN: INTERNATIONAL CONGRESS OF PLANT PATHOLOGY, 5., Kyoto, 1988. Abstracts. Kyoto: Japanese Society of Plant Pathology, 1988. p.288.

YORINORI, J.T. Management of foliar fungal diseases in Soybean in Brazil. In: COPPING, L.G.; GREEN, M.B.; REES, R.T. (Ed.). Pest Management in Soybean. London: Elsevier Applied Science, 1992. p.185-195.

YORINORI, J. T. Ferrugem da soja: panorama geral. In: WORLD SOYBEAN RESEARCH CONFERENCE, 7., / INTERNATIONAL SOYBEAN PROCESSING AND UTILIZATION CONFERENCE, 4., / CONGRESSO BRASILEIRO DE SOJA, 3., Foz do Iguaçu, 2004. Proceedings. Londrina: Embrapa Soybean, 2004.

YORINORI, J.T; ARIAS, C.A.A. Determinação do nível de perdas e o estádio da soja em que as doenças de final de ciclo (mancha-parda - Septoria glycines e crestamento foliar - Cercospora kikuchii) afetam o rendimento. In: EMPRESA BRASILEIRA DE PESQUISA AGROPECUÁRIA. Resultados de Pesquisa de Soja 1988/89. Londrina: EMBRAPA, Centro Nacional de Pesquisa de Soja, 1989. 405p. (Documentos, 43)

YORINORI, J.T.; CHARCHAR, M.J. D’AVILA; NASSER, L.C.B. ; HENNING, A.A. Doenças da soja e seu controle. In: ARANTES, N.E.; SOUZA, P.I.M. de. (Ed.). Cultura da soja nos cerrados. Piracicaba: POTAFOS, 1993. p.333-397. 
YORINORI, J.T.; MOREL, P.W.; FREDERICK, R.D.; COSTAMILAN, L.M.; BERTAGNOLLI, P.F. Epidemia de ferrugem da soja (Phakopsora pachyrhizi) no Brasil e Paraguai, em 2001 e 2002. In: Congresso Brasileiro de Fitopatologia, 35., Recife, 2002. Resumos. Brasília: Fitopatologia Brasileira, 2002. Suplemento, v.27, p.178-179.

YOUNG, L.D.; ROSS, J.P. Resistance evaluation and inheritance of a nonclorotic response to brown spot of soybean. Crop Science, v.18, p.1075-1077, 1978.

YOUNG N.D.; TANKSLEY S.D. RFLP analysis of the size of chromosomal segments retained around the Tm-2 locus of tomato during backcross breeding. Theoretical and Applied Genetics, v.77, p.353-359, 1989.

YU, Y.G., SAGHAI MAROOF, M.A., BUSS, G.; MAUGHAN, P.; TOLIN, S. RFLP and microsatellite mapping of a gene for soybean mosaic virus resistance. Phytopathology, v.84, p.60-64, 1994.

YUAN, J.; NJITI, V.N.; MEKSEM, K.; IQBAL, M.J.; TRIWITAYAKORN, K.; KASSEM, M.A.; DAVIS, G.T.; SCHMIDT, M.E.; LIGHTFOOT, D.A. Quantitative trait loci in two soybean recombinant inbred line populations segregating for yield and disease resistance. Crop Science, v.42, p.271-277, 2002.

ZABEAU, M.; VOS, P. Selective restriction fragment amplification: a general method for DNA fingerprinting. European Patent Application Nº534858 A1, 1993.

ZAMBOLIM, L.; do VALE, F.X.R.; CHAVES, G.M. Partial resistance of soybean cultivars to Phakopsora pachyrhizi. Fitopatologia Brasileira, v.8, p.117-122, 1983.

ZENG, Z. B. Precision mapping of quantitative trait loci. Genetics, v.136, p.1457-1468, 1994. 